\title{
CEO turnover and volatility under long-term employment contracts
}

\author{
Peter Cziraki $^{*} \quad$ Moqi Groen-Xü
}

July 2018

\begin{abstract}
We study the role of the contractual time horizon of CEOs for CEO turnover and corporate policies. Using hand-collected data on 3,954 fixed-term CEO contracts, we show that remaining time under contract predicts CEO turnover. When contracts are close to expiration, turnover is more likely and is more sensitive to performance. We also show a positive within-CEO relation between remaining time under contract and firm risk. Our results are similar across short and long contracts and are driven neither by firm or CEO survival, nor technological cycles. They are consistent with incentives to take long-term projects with interim volatility.
\end{abstract}

Keywords: Risk taking, volatility, career concerns, CEO contracts, CEO turnover JEL classifications: G34, J41, J63

\footnotetext{
We are grateful to an anonymous referee, Pat Akey, David Denis, Alex Edmans, Andrew Ellul (discussant), Daniel Ferreira, Juanita Gonzalez-Uribe (discussant), Jonathan Hall, Jarrad Harford, Dirk Jenter, Katharina Lewellen (discussant), Stefan Lewellen (discussant), David Koslowsky (discussant), James S. Linck (discussant), Robert McMillan, Daniel Paravisini, Luc Renneboog, David Robinson, Michel Serafinelli, Rui Silva, and Morten Sørensen (discussant) as well as participants at the CEAR Symposium on Corporate Control Mechanisms and Risk, the 2014 European Finance Association Meetings, the 2015 Financial Intermediation Research Society Conference, the 2016 Young Scholars Finance Consortium, the 2014 Northern Finance Association Meetings, the 2014 WBS Frontiers of Finance Conference, and seminars at the University of Geneva, University of Toronto, and York University for their comments. We also thank Steve Hillegeist, Holger Jahn, Christian Maennlin, and Jean-Luc Mauron for useful discussions on disclosure and contract design practice, and Dirk Jenter, Fadi Kanaan, Florian Peters, and Alexander Wagner for sharing their turnover data. Peter Cziraki acknowledges financial support from CentER and TILEC at Tilburg University and from a SSHRC Institutional Grant. Moqi Groen-Xu acknowledges financial support from the INSEAD Alumni Fund.

*Corresponding author. University of Toronto, peter.cziraki@utoronto.ca, +1 416 9463298, Fax: +1 4169786713

\# London School of Economics, m.xu1@1se.ac.uk, +44 207849 4654, Fax: +44 2078494647
} 
Differences in time horizon can create conflicts of interests between shareholders and management. Firm value maximizing decisions should trade off short-term and long-term cash flows based on shareholders' discount rates. However, theory suggests that the threat of dismissal gives risk-averse managers an incentive to avoid profit-maximizing but unobservable actions with long-term returns (Holmstrom 1982; Holmstrom and Ricart i Costa 1986; Knoeber 1986; Lipton 1987; Almazan and Suarez 2003; Goel and Thakor 2008; Gormley and Matsa 2016). Consistent with this, Jenter and Lewellen (2017) show empirically that the relationship between CEO turnover and past performance is asymmetric: turnover is concentrated at low levels of performance and is almost insensitive to performance at the top. Therefore, volatility increases in the short-run are costlier to executives than to the firm, as they increase turnover probability at low performance levels more than they decrease turnover probability at the top.

The long-term contract is theoretically the direct instrument to set a long-term career horizon, similar to election cycles in politics (Alesina, Roubini, and Cohen 1993) and on boards (Fos and Tsoutsoura 2014). Long-term contracts offer CEOs protection from turnover by making dismissal more expensive for the firm CEO early on in the contract. This protection from dismissal can encourage CEOs to take profit-maximizing projects with initially negative or volatile returns. Yet, the question emerges whether long-term contracts do indeed matter in practice, and if so, how.

To better understand the role of long-term contract periods empirically, we introduce the first large-scale sample of CEO employment contracts. Filing CEO contracts is mandatory for US-listed firms. We hand-collect 3,954 contracts and record, for each one of these contracts, the start and the expiration dates. Our sample is the largest and most comprehensive known sample 
of CEO employment contracts. ${ }^{1}$ We start by documenting stylized facts. Most employment contracts are between one and five years long, with an average length of three years. Contract lengths do not match the distance between peaks or troughs in variables that may indicate a natural firm time horizon, such as capital expenditures (CAPEX), sales, or depreciation. Instead, contract length seems to be a relevant factor in negotiations. Consistent with a negotiation role of long-term contracts, we find that firms in more isolated locations write longer contracts.

The time remaining under CEO contracts predicts actual turnover outcomes. The turnover odds are $73 \%$ lower for CEOs with five years remaining to expiration than for CEOs in the year before contract expiration. The probability of turnover decreases sharply (by 15\%) from the year just before contract renewal to just afterwards. Turnover is also only sensitive to performance for CEOs in the three years before contract expiration. These results imply that contracts indeed provide protection from turnover, consistent with Liu and Xuan (2016) who document more earnings manipulation in the year before contract expiration. Premature turnover has real costs to CEOs: only few of them transition smoothly into an equivalent or better position subsequently.

How do corporate policies change over the course of a contract? Relying on within-CEO variation, we report patterns in corporate policies that are correlated with the time remaining under each contract and change at the time of contract renewals. Each additional year remaining to contract expiration translates into 3.3-bp higher stock return volatility. Upon contract renewals, volatility increases sharply by 23 bps from the year before to the year after renewal. ${ }^{2}$

\footnotetext{
${ }^{1}$ Gillan, Hartzell, and Parrino (2009) introduce employment contracts to the finance literature by way of 255 explicit contracts (valid in 2000) of S\&P 500 firms. Liu and Xuan (2014) study earnings management in the year before renewal for 159 contracts.

${ }^{2}$ This 23 bps corresponds to $13 \%$ of the standard deviation of volatility or $7 \%$ of its mean. This economic effect is similar to the effect of compensation (Coles, Daniel, and Naveen 2006), or exposure to rare disasters early in life (Bernile, Bhagwat, and Rau 2017), and larger than the effect of marital status (Roussanov and Savor 2014).
} 
The changes in volatility are driven by idiosyncratic rather than systematic risk and coincide with changes in investment and leverage.

Why is volatility higher at the beginning of long-term contracts? The insurance character of contracts gives risk-averse CEOs incentives to invest in profit-maximizing actions that are unobservable or risky in the short run (Holmstrom 1982; Almazan and Suarez 2003; Manso 2016). First, we show that the relation between contract horizon and risk is stronger where career concerns are stronger. Career concerns are likely of lesser importance for CEOs just short of retirement, founders, and CEOs with higher tenure. Indeed, the risk patterns we document are less pronounced for old, founder, and high-tenure CEOs. Second, an alternative explanation for our results would be if boards could predict technological cycles several years into the future and set contract lengths accordingly. It is more difficult to predict the length of technological cycles in faster-moving industries, so selection effects should be weaker in such industries. However, we show that the horizon-risk relationship is stronger in dynamic industries (measured using the product market fluidity measure of Hoberg, Phillips, and Prabhala (2014)), although the difference is not statistically significant. This pattern suggests that selection effects are not the only explanation for our findings.

We rule out several mechanical explanations for our results. Our main measure, the time to $\mathrm{CEO}$ contract expiration, delivers two sources of within-CEO variation: the decline of contract horizon over time within a contract and the sharp rise in contract horizon at contract renewal. These sources of within-CEO variation allow us to compare the volatility of a given firm-CEO pair at different points in the CEO's contract. Since the contract length is determined ex ante and without precise information about the outcome of future risk-taking decisions, we can isolate contract-related effects from ex post effects of actual risk-taking. As we have several 
observations for each contract, we can measure the effect of contract horizon within each CEO, even though the contract is likely to be chosen endogenously. In addition, the sharp increase of the measure at the time of contract renewal allows us to isolate the effects of contract horizon from other time-varying measures, such as tenure, age, and firm-specific trends. Our results also hold when we directly control for tenure and age fixed effects.

Our finding of an increase in volatility right after contract renewal excludes the majority of alternative explanations based on firm or CEO life cycles. However, it is still possible-in fact, likely - that investment opportunities are correlated with CEO contract cycles. The hiring of a new CEO may coincide with unusually good or bad investment opportunities, which then revert to the mean over the subsequent years.

Such natural cycles related to investment opportunities are likely to be present in both firms with and without CEO contracts. However, the relation between volatility and cycles in investment, sales, or depreciation in firms without fixed-term CEO contracts is either insignificant or, when significant, works in the opposite direction compared to our results for fixed-term contracts. Firms without fixed-term CEO contracts also do not exhibit the pattern of a decline in volatility after abrupt increases that we see for firms with fixed-term contracts after renewals. One may argue that firms that sign contracts are able to predict cycles better than other firms. However, our results are stronger in fast-moving industries where it may be more difficult to predict such cycles. One may also argue that CEOs with longer contracts account for most of the observations with long contract horizon, and therefore selection into such contracts may drive our results. However, our findings hold when we use the fraction of contract time instead of years remaining, as well as in subsamples of CEOs with both long- and short-term contracts. 
Volatility can change with CEO tenure. Pan, Wang, and Weisbach $(2015,2016)$ describe two tenure-related effects. First, the hiring of a new CEO is often associated with major changes in the firm, causing volatility to first be high and then gradually decline, predicting (for the first contract of a CEO) similar findings to ours on volatility (Pan, Wang, and Weisbach 2015, see also Clayton, Hartzell, and Rosenberg 2005). Second, a new CEO can reverse negative-NPV projects of the former CEO and, subsequently, embark on value-destroying projects herself. This predicts (for the first contract of a CEO) the opposite of our findings on capital investment and no variation for later contracts (Pan, Wang, and Weisbach 2016). We distinguish our results from these tenure-related effects by controlling flexibly for tenure and by comparing the level of risktaking in the last year of a CEO's contract to the level of risk-taking in the first year of the same CEO's next contract. Our results also hold when we use the subsample of CEOs whose contracts have been renewed. Another concern is that volatility could follow a firm-specific downward trend. However, while such trends should continue throughout renewal years, we observe that volatility changes sharply around such years. Finally, our findings are robust to controlling for selection into our sample and, separately, for firm fixed effects; they hold also when we control for age, tenure, or CEO compensation.

Our analysis makes several contributions to the existing literature. First, we contribute to the literature on CEO turnover. Debates in this area have focused on how CEO turnover is related to firm performance and corporate governance (e.g. Warner, Watts, and Wruck 1988; Weisbach 1988; Jenter and Kanaan 2015; Jenter and Lewellen 2015). We introduce a predictor of CEO turnover that substantially improves the precision of turnover models; in particular, this predictor identifies the years in which CEO turnover is and is not performance-sensitive. 
Contracts per se are also an important subject for the literature, as they are firms' primary means to establish a schedule of time horizon and evaluations.

Second, our work adds to the literature on long-term incentives by establishing an empirical link between CEO-specific contract horizon and volatility. A recent literature on CEO incentives examines the effect of changes in firm-specific risk. For instance, Gormley and Matsa (2011) study the risk arising from large, left-tail events in terms of shocks to job security, while Low (2009) reports changes in risk-taking behavior after legislation in Delaware increased protection against takeovers. Whereas Gormley and Matsa (2011) find that managers reduce operational risk in response to increased exogenous risk, Low (2009) finds the managers reduce operational risk in response to reduced exogenous risk. Furthermore, Garfinkel, Kim, and Lee (2013) argue that the latter effect is driven by older CEOs who are more insulated from career concerns in the event of a takeover. Another strand of the literature links investment to the duration of CEO incentives. Murphy and Zimmermann (1993), Matta and Beamish (2008), Antia, Pantzalis, and Park (2010), and Lee, Park, and Folta (2018) link investment to the CEO's ex-post tenure or an expectation of her future tenure computed using industry averages. Gopalan et al. (2014), Edmans, Fang, and Lewellen (2017), and Ladika and Sautner (2018) study how long-term equity compensation affects investment. We contribute to this literature by documenting effects of long-term contracts on long-term investment with short-term volatility.

Finally, we contribute to the empirical literature on CEO employment contracts. Schwab and Thomas (2005) describe a sample of 375 contracts from a legal perspective. Gillan, Hartzell, and Parrino (2009) report that many CEOs operate without a contract and discuss the choice between an explicit and an implicit contract. Building on their work, we show that explicit contracts not only exist but actually translate into career outcomes as they promise to, despite the 
potential cost of adhering to them and the built-in legal possibilities to renege on them. We then focus on corporate policies throughout the contracts and link contract horizon to volatility.

\section{The role of long-term contracts: Institutional background and conceptual framework}

\subsection{Institutional background}

In a fixed-term employment contract, the firm commits to paying compensation for a certain number of years and is obligated to do so even if the employee is terminated and replaced prematurely. As an immediate consequence, the cost of termination is increasing in the numbers of years left under the contract. An executive terminated early is typically entitled to a multiple of the base salary and the minimum bonus, although this sum can be augmented contractually. As an example, consider John Mack’s 2005 five-year contract with Morgan Stanley:

If, during the Employment Period, the Company shall terminate the Executive's employment other than for Cause, death or Disability or the Executive shall terminate employment for Good Reason: (i) the Company shall pay to the Executive in a lump-sum cash payment as soon as practicable after the Date of Termination the aggregate of the following amounts:

[...] an amount equal to the product of (1) the Executive's Total Compensation for the most recently completed fiscal year and (2) the greater of $(x)$ a fraction, the numerator of which is the number of days from the Date of Termination through the fifth anniversary of the Effective Date, and the denominator of which is 365 and (y) $1 .{ }^{3}$

\footnotetext{
${ }^{3}$ Morgan Stanley, Form 8K, Exhibit 10, filed on September 22, 2005. Cause refers to exceptions that allow the firm to dissolve the contract due to failure to perform duties, engagement in fraud and misconduct, conviction of a felony, material violation of Company policies, and breaches of the contract's confidentiality section.
} 
Therefore, in Mr. Mack's case, the cost of dismissal prior to contract expiration is the product of his total compensation and the number of years remaining until the contractual termination date. The total compensation of Mr. Mack was $\$ 45$ million in 2006, the first year of his employment contract; therefore, severance pay for termination in 2006 would have exceeded $\$ 182$ million. Assuming that his compensation remains at this level, severance pay in 2009 would have been only $\$ 45$ million (i.e. $\$ 137$ million less). ${ }^{4}$ For the turnover decision, the potential severance pay should be compared with the potential benefits of dismissing a CEO prematurely. In 2006, Morgan Stanley's net income was $\$ 7.5$ billion: a bad CEO could have destroyed value worth much more than the severance package. To put these numbers into perspective: the median compensation-to-net income ratio is $2 \%$ in our sample, as compared to $1 \%$ for Mr. Mack. Thus, one way to interpret contracts is as an implicit commitment where premature dismissal causes non-trivial costs of a magnitude that may render turnover still beneficial.

\subsection{Contracts and the role of turnover}

Formally, long fixed-term contracts provide financial insurance against early termination to the employee: they receive compensation through the term of their contract even if they are terminated without cause. Thus, the contract establishes the amount of severance pay as a function of time. Financial insurance in the form of severance pay is more valuable to a riskaverse employee than to a risk-neutral firm. Hence, it can allow the firm to negotiate more favorable other terms, such as lower compensation. In addition, the high severance at the beginning of the contract discourages the firm from replacing the CEO with a marginally better candidate early on and thus creates commitment. This commitment in turn changes the CEO's

\footnotetext{
${ }^{4}$ See Rusticus (2006), Dahiya and Yermack (2008), Goldman and Huang (2015), and Rau and Xu (2013) for further details on severance pay.
} 
incentives. These effects of fixed-term contracts on CEO compensation and incentives are present independently of the specific reasons for CEO dismissals, which we discuss next.

As Jenter and Lewellen (2017) show empirically, CEO turnover is concentrated at low levels of performance and is almost insensitive to performance at the top. Hence, a CEO with career concerns has more to lose from bad outcomes than to gain from good ones.5 The asymmetry of turnover-performance sensitivity is consistent with moral hazard and learning models of turnover. First, the threat of dismissal disciplines CEO behavior (Weisbach, 1988; Morck, Shleifer, and Vishny, 1989; Denis, Denis, and Sarin, 1997; Mikkelson and Partch, 1997; Hartzell, 1998; Bertrand and Mullainathan, 2003). CEOs whose performance indicates that they did not exert enough effort or shirked are punished by being fired. Second, by observing performance over time, a firm may learn that its CEO is of low quality or a bad match (Hermalin and Weisbach 1998, Aghion and Jackson 2016, Vladimirov 2017) and, therefore, dismiss her. Finally, a firm may also dismiss its CEO because the firm's circumstances and needs change, causing the CEO to no longer be the best match (Anderson et al. 2018). This is especially relevant if a CEO with a particular skill set was selected for a particular task, such as implementing a strategy chosen by the board. Indeed, Jenter and Lewellen (2017) find evidence consistent with the quality of the CEO-firm match changing over time.

As a consequence, compensation incentives that connect managerial wealth to the upside of risky projects are an inefficient means to motivate CEOs to take on projects with substantial downside (and hence turnover) risk. In contrast, long-term employment contracts can provide insurance against low-performance states.

\footnotetext{
${ }^{5}$ A back-of-the-envelope-calculation using the turnover-performance sensitivity coefficients of Jenter and Lewellen (2014) shows that turnover probability differs by $5.08 \%$-points between the lowest and the third lowest decile of returns. By contrast, the turnover probability difference between the $10^{\text {th }}$ and $8^{\text {th }}$ deciles is only $1.57 \%$-points. In addition, the post-turnover career outcomes for managers are also worse on the downside (see Section 2.5).
} 
In reality, all three of the above motives are likely to explain CEO turnovers. Firms dismiss CEOs if bad performance suggests shirking, low ability, or a bad match, and firms dismiss CEOs who have completed the project they were hired for. Consequently, CEOs are likely to choose their actions with these possibilities in mind and avoid projects that increase the probability of bad performance or of worsening the CEO-firm match. Long-term contracts can serve as commitment to not dismiss the CEO quickly, alleviating the CEO's career concerns and inducing her to take actions she otherwise would not.

All three motives for CEO turnover predict that turnover should be low in the early years of a fixed-term contract, and high towards its end. The turnover-performance sensitivity increases towards the end of a fixed-term contract if the purpose of CEO turnover is to penalize CEOs for shirking or to replace low-ability CEOs. If, however, CEOs are let go at the end of a contract simply because the task they were hired for is complete, there is no reason to expect the turnover-performance sensitivity to change over time. Finally, the optimal contract length is determined by how long it takes for the consequences of CEO actions to fully reveal themselves, or by the expected length of the task the $\mathrm{CEO}$ was hired for.

The insurance provided by a fixed-term contract should be especially valuable for certain types of hires. First, CEOs hired from outside the firm have a higher cost of settling into their role. They also have weaker relationships with board members and less firm-specific human capital. Therefore they may prefer a contract that gives them time to adjust before a formal assessment of their ability or the quality of their match with the firm. Second, firms operating in more uncertain environments are more likely to encounter situations where it is advantageous to replace the CEO. The insurance provided by a fixed-term contract can therefore be more valuable to CEOs of such firms. Consistent with these arguments, Gillan et al. (2009) show that 
outside hires and firms operating in riskier environments are indeed more likely to sign longer CEO contracts. Our first testable prediction is on how contracts are awarded: the length of fixedterm contracts is determined by uncertainty about the CEO and about the firm's prospects.

For contracts to be useful as a commitment device, they cannot be not empty promises. The third testable prediction is that CEOs are more likely to be dismissed when their contract horizon (time remaining on the contract) is short. When evaluating the CEO, the firm weighs the cost of firing the CEO versus the benefit of replacing her with a potentially better CEO. The fourth prediction is that CEO turnover should be more sensitive to performance when the contract horizon is short.

\subsection{Long-term contracts and volatility}

The different roles of turnover imply different volatility patterns through the term of a contract. First, a long-term contract can provide incentives for executives to take actions that are not reflected in performance until future periods. This is useful if such actions are optimal for the firm but not for a CEO who fears early turnover. Hence, long-term contracts motivate CEOs to take actions that are ultimately positive-NPV, but may temporarily be observationally equivalent to a bad CEO-firm match, low CEO ability, or shirking. The key friction that long-term contracts can alleviate is transient volatility of ultimately profitable projects. This stands in contrast with the stylized form of myopia models as in Narayanan (1985) and Stein (1989), where investment opportunities are common knowledge, as is the myopic action that arises in equilibrium. While that setup is useful to illustrate the issue of "short-termism", explicit contracting on the desired action can eliminate the problem (Darrough 1987, Von Thadden 1995, Edmans 2011). However, explicit contracting is impossible when transient performance effects are observationally 
equivalent to undesirable things such as low ability or shirking and hence may lead to punishment for the manager, as illustrated in Shleifer and Vishny (1997). Although such "longterm" incentives do not necessarily involve risk-taking, they thus predict a distinctive pattern of declining volatility throughout the contract and an abrupt increase at renewals as managers under a longer contract horizon are encouraged to take on actions that can be volatile in a transient phase.

Long-term contracts set incentives differently from long-term equity compensation. While Holmstrom (1982) and Manso (2016) argue that compensation can incentivize managers to take uncertain projects, Glover and Levine (2017) and Dittman, Maug and Spalt (2008) show in calibrations that this is not always possible. This is because the threat of turnover makes poor performance costly. Stock-based compensation only allows the CEO to benefit from the upside of risky strategies. Long-term contracts, in contrast, provide insurance to downside risk. Therefore, they can encourage projects with downside risk while compensation incentives cannot.

Second, without uncertainty about the quality of the match - if the contract length matched to a specific task and the executive is dismissed after she completes this task - there is no reason to expect any correlation between volatility and the time remaining under the contract. This is because the market has all the information about the actions and projects taken throughout the contract in advance. We term this the selection argument. Uncertainty about the identity of the next task facing the firm, or the next CEO may lead to an increase in volatility towards the end of the incumbent CEO's contract.

Third, a pure learning argument - without incentive effects of contracts - predicts that volatility should decline during the tenure of the CEO (Pan, Wang, and Weisbach 2015). The 
decline in volatility should be monotonic over time, and volatility should not increase at contract renewals. The decreasing pattern in volatility should be driven by idiosyncratic risk. Observed stock return volatility is likely shaped by all three channels: incentives, selection, and learning.

Contractual incentives can also lead to a negative relation between CEO contract horizon and risk. First, recent work has identified inside debt (defined as payments to the CEO in unsecured fixed claims) as a way to mitigate managerial risk-taking (Edmans and Liu 2011). Inside debt includes nonqualified defined-benefit pensions and deferred compensation accounts, but would also include unsecured claims to future salaries promised in employment agreements. A longer contract horizon thus implies a higher level of inside debt. As Sundaram and Yermack (2007) and Cassell et al. (2012) find, higher inside debt is associated with less risk, thus creating a negative relationship between contract horizon and risk-taking. Second, "gambling for resurrection" - observed for example in the contexts of asset substitution (Jensen and Meckling 1976) and mutual fund managers (Chevalier and Ellison 1997; Kempf, Ruenzi, and Thiele 2009; Hu et al. 2011; Huang, Sialm, and Zhang 2011) - may induce higher return volatility when the time to contract expiration is short. For the CEO to engage in such behavior, she must take on short-term projects towards the end of her contract so that she can enjoy the potentially high payoffs in the immediate future. This would lead to higher volatility towards the end of the contract. The alternative prediction is therefore that CEO contract horizon is negatively related to risk. Concerning contract renewals, inside debt, speculation about turnover and succession, and gambling for resurrection would predict also that risk decreases following contract renewals. 


\section{Data}

\subsection{Information on contracts and descriptive statistics}

Regulation S-K of the Securities Exchange Act of 1934 requires disclosure of the terms of employment contracts and agreements between US registrants and named executive officers. Following Schwab and Thomas (2005) and Gillan et al. (2009), we collect explicit contracts from SEC filing exhibits and, when available, from The Corporate Library. For all S\&P 1500 firms that do not file an explicit contract, we read all proxy filings and 10-Ks to obtain summaries of contract terms. Some executives sign at-will employment agreements that include compensation and severance clauses, but do not specify any employment period. No such agreements are included in our main sample. For 81 renewals in 1994 and 1995, we use the renewal agreement to obtain the characteristics of the original contracts that were not filed electronically. Excluding these observations does not significantly alter our results. We obtain separation dates from ExecuComp, Risk Metrics, or BoardEx.

Our sample contains the data on 3,954 fixed-term employment contracts entered into between January 1, 1992 and December 31, 2008, for 2,964 CEOs and 2,901 firms. Table 1 reports descriptive statistics. Panel A in Table 1 reports the number of contracts by length. Most contracts are for less than six years; the modal value is three years (1,515 contracts), followed by two-year (741) and five-year contracts (551). Of the 39 contracts for longer than ten years, 12 are explicitly linked to the executive's retirement age. Altogether, 28 contracts in our sample are explicitly linked to age. As Jenter and Lewellen (2015) show, such linkage typically occurs when the CEO's age reaches 65 (23 contracts). Most of the 64 contracts of less than a year's duration are renewals effective until the end of the calendar year (38 contracts); the remaining 26 contracts in this group are for interim CEOs. The so-called evergreen contracts, i.e. those that are 
automatically renewed every day or month to retain the same time to contract expiration, are not frequent (73 contracts in total). Since, despite their official remaining duration, such contracts are typically discontinued at non-renewal for privacy and loyalty reasons, practitioners regard evergreen contracts as equivalent to contracts with no fixed term in terms of turnover patterns. For each contract of a given type and length, we indicate what percentage it constitutes among all the sample contracts of that type.

\subsection{Selection into contract types}

Panel B in Table 1 shows the characteristics of our sample firms in the fiscal year before the contract starts. We measure most variables on a fiscal year basis, except volatility. As contract start dates and turnover dates typically do not coincide with fiscal year ends, we match them to the appropriate fiscal year and label them as " $t$ to $t+1$ years remaining" in our regressions. The mean firm size (as measured by assets) of our sample firms is $\$ 1,379$ million, return on assets (ROA) is $1.1 \%$, annual stock returns are $2.4 \%$, and the average market-to-book ratio is 2.54 . As a rough estimate of the time horizon of the firm, we also provide the average time between peaks (and between troughs) in CAPEX, sales, and depreciation (where peaks and troughs are defined as reversals after a year of growth/decline over 5\%). The average cycle time is five years between peaks and six years between troughs, i.e. roughly twice as long as the average contract.

Consistent with the results of Gillan et al. (2009), we find differences between firms with versus without fixed-term CEO contracts (i.e. CEOs employed at will). Firms that enter fixedterm contracts are on average smaller and perform worse than firms without fixed-term contracts. They are also more levered and have more idiosyncratic risk, but less systematic risk. This is not because they grow more or invest more: they have lower market-to-book ratios and invest less in 
R\&D and CAPEX than firms without fixed-term contracts. In terms of firm-level time horizon, firms without fixed-term CEO contracts have shorter cycles peak-to-peak but longer ones troughto-trough, compared to those with fixed-term contracts. This suggests that firms with contracts do not systematically have shorter or longer "natural" time horizons. These cycles are also do not seem more likely to change ex post: firms without contracts operate in less dynamic markets (measured using the product market fluidity measure of Hoberg, Phillips, and Prabhala 2014).

Next, we compare firms that enter into different contract lengths. Table 2 shows regressions of contract length on firm and CEO characteristics. Firms with high analyst forecast dispersion enter into significantly shorter contracts, suggesting that less information about future outcomes reduces contract length. We also examine whether firms grant longer contracts if they would have a difficult time finding a CEO otherwise. Indeed, we find that firms whose headquarters are not in a metropolitan statistical area grant significantly longer first contracts. In contrast, firms with poor past performance (ROA or stock returns) grant shorter contracts, suggesting that assessing CEO ability and match quality is especially important to such firms. Firm size, product market fluidity (Hoberg, Philips, and Prabhala 2014) and whether the CEO is a generalist or a specialist (Custodio, Ferreira, and Matos 2013) are not significantly related to contract length.

Panel $\mathrm{C}$ in Table 1 reports summary statistics for firm-years under the previously described fixed-term contracts. These contracts constitute the sample for our subsequent analysis. The average firm in our sample has $\$ 1.8$ million in total assets, ROA of $4.6 \%$, annual stock returns of $11 \%$, market-to-book ratio of 2.7 , and leverage of $22 \%$. We use three measures of risk: volatility, beta, and idiosyncratic risk. Volatility is the standard deviation of daily stock returns; beta is the market beta from a Fama-French three-factor model estimated using one year 
of daily data; and idiosyncratic risk is the standard deviation of the residuals from that model. We calculate all three volatility measures for contract years (12 month periods counting from the effective date), using the effective date and the expiration date of each contract. The mean volatility is $3 \%$, the mean beta is 0.90 , and the mean idiosyncratic risk is $2.8 \%$. On average, our sample firms spend $4 \%$ of their asset value on R\&D and $7 \%$ on CAPEX.

Panel $\mathrm{C}$ also gives descriptive statistics of CEO and corporate governance characteristics. The mean CEO age is 54 years and $53 \%$ of the sample firm-years are under renewed contracts. On average, a CEO receives $\$ 5.9$ million in total compensation (TDC1, inflation adjusted to year 2000). More than half (52\%) of the CEOs also hold the position of chairman. Our main variable, remaining years, has a mean of 2.47 and a standard deviation of 2.29.

\subsection{Fixed-term contracts as part of contract negotiation}

In negotiations between the CEO and the firm, the ability to offer a fixed-term contract can affect the trade-off between career concerns and compensation. Risk-averse managers are likely to value the insurance provided by longer contracts more than risk neutral firms. As Gibbons and Murphy (1992) show theoretically, the optimal contract maximizes the sum of the implicit incentives from career concerns and the explicit incentives from compensation. Thus, a longer contract may make the manager willing to forgo other compensation, or accept a risky position to begin with. For a risk-neutral firm, a sum equal to a multiple of annual CEO compensation is less relevant, although not trivial (Kuhnen and Niessen, 2012). Thus, from the firm's perspective, longer contracts can provide benefits in addition to any incentive effects, which may further offset the cost of having longer, less flexible contracts. One possible prediction is therefore that 
CEOs with fixed-term contracts receive lower compensation, and lower incentive pay, than CEOs employed at will. This difference in compensation should be larger for external hires.

Ultimately, it is difficult to use our sample to test whether contracts are optimal since we do not observe the counterfactual: compensation for a CEO with long contract may be lower than with a short contract, but may still be high compared to similar-looking firms. Longer contracts may coincide with high compensation because those firms had difficulty attracting CEOs (e.g., distressed firms, as in Chang et al. 2016) and thus had to offer more compensation as well as longer contracts. Because top executive labor markets are matching markets (Gabaix and Landier 2008; Tervio 2008; Gayle et al. 2015), it is also possible that unobservable traits such as the perceived match quality between the firm and the CEO dominate the effect of compensation. In our analysis of risk, we purposely choose our empirical approach to mitigate these concerns by including CEO fixed effects in the regressions (which are also CEO-firm fixed effects since no CEO moves firms within our sample).

To examine the trade-off between contract length and pay, in Table 3 we regress measures of compensation on indicators for fixed-term contracts and CEOs hired externally, as well as firm size and industry fixed effects. We use the first year of each CEO as compensation in later years is a function of performance, although we obtain similar results if we include later years. Generally, the salary and total compensation of fixed-term and at-will CEOs is not significantly different. Column 2 shows that the salary of CEOs hired from outside the firm is lower in general, but not if they are hired on a fixed-term contract. This pattern is similar for total compensation, but not statistically significant. Fixed-term CEOs receive significantly, 15-17\% higher cash compensation. They also receive slightly less of their pay in the form of incentive 
compensation (Columns 7-8), although the coefficients are not statistically significant. These latter two results are consistent with the notion that fixed-term CEOs are more risk-averse.

\section{Contracts and career outcomes}

We introduce remaining time under contract as a predictor of turnover probability and document the average turnover time profile under ex-ante contracts. Our null hypothesis is that there is no correlation between the remaining time on the CEO's contract and the turnover probability. This would indicate that contract expiration terms are empty promises: they may matter for CEOs in that they provide them with severance ex post, but are otherwise inconsequential.

\subsection{Contracts and turnover probability}

The probability of turnover varies over the course of the contract, becoming more likely at the end. Panel A in Table 4 shows the probability of turnover by the number of years remaining (columns) and length of contracts (rows). Turnover can occur at any time during a contract, not only at its expiration. For example, CEO turnover took place in $4 \%$ of all years in which CEOs had five years remaining under five-year contracts. Conditional on survival, turnover probability under five-year contracts then increases with every year closer to contract expiration, reaching a conditional turnover probability of $32 \%$ for the expiration year. Overall, the unconditional turnover likelihood in our sample is $11.49 \%$, which is similar to the value of $11.82 \%$ reported by Jenter and Lewellen (2017) and lower than the 15.8\% reported by Kaplan and Minton (2012). For the interpretation of these results, note that some contracts continue beyond 2008 , i.e. the end of our sample period for which we track turnovers. 
The relation between turnover probability and time to contract expiration reflects not only the financial consequences of terminating a contract, but also the role that contract horizons play in the evaluation of executives. As the expiration date approaches, an unfavorable prognosis can prompt both parties to seek other options, leading to an increased rate of turnover close to, but before the expiration date. This is consistent with the observed pattern of increasing turnover likelihood throughout a contract.

A comparison of the turnover rates under different contract lengths shows also that the steepness of the increase in turnover probability throughout contracts differs by contract length. Panel B in Table 4 summarizes career outcome statistics by contract length. The observational unit for this Panel is one contract, in contrast to Panel A, where it is one firm-year (and hence conditional on surviving up to that year). Shorter contracts have generally a lower probability of premature termination, but a higher probability of termination at the contract end. This results in a relatively even distribution of the probability of renewal between contracts of different length.

Table 4 Panel B shows that many CEOs receive a contract that is the same length as the previous one. In fact, $48 \%$ of CEOs completing a two-year contract receive another two-year contract, and $60 \%$ of CEOs completing a three-year contract receive another three-year contract. If the board expected the CEO to remain in office for four (six) years, and this was their most important consideration when choosing contract length, they could have chosen to offer one four-year (six-year) contract instead of 2 two-year (three-year) contracts. Of course, having the opportunity to dismiss the CEO after two years may still be optimal ex ante, but the renewal of these contracts suggests that our turnover results are not driven purely by boards selecting the contract length accurately at the initial hiring of the CEO. Hence, these results suggest that selection or learning about CEO ability are not the only channels underlying our results. 
Contracts are typically renewed at, or shortly before, expiration. Panel C in Table 4 shows that most contracts are renewed in the year of expiration $(36 \%)$ or in their penultimate year (37\%). Only $8.8 \%$ of contracts are renewed with 3 years or more remaining. Table 4 Panel D shows that the percentage of contracts renewed early increases with original contract length. Even so, $60 \%$ of five-year contracts, and $75 \%$ of three-year contracts are renewed in their last or second-to-last year. The average remaining time on a five-year (three-year) contract at renewal is $1.43(0.93)$ years.

Contract horizon may be correlated with other time-varying variables. Figure 1 shows that turnover probability does not have a systematic relation with tenure or age, except for the retirement-related peak around age 65. Figure 1 also shows turnover rates for CEOs employed under at-will contracts, the majority of whom have severance pay equal to 2 or 3 times base pay. Indeed, we see similar turnover rates for fixed-term and at-will CEOs up to 4 years of tenure. ${ }^{6}$

\subsection{Multivariate tests of turnover}

We now use a multivariate setting to examine how remaining time on the CEO's contract relates to turnover probability. We start by estimating the following OLS model:

$$
\lambda_{i t}=\alpha+\sum_{h=1}^{>5} \beta_{h} D_{i t T-h}+\varphi \boldsymbol{s}_{i t}+\rho_{i}+\gamma_{t}+\varepsilon_{i t} .
$$

where $i$ indexes firms, $t$ indexes time, $D_{i t T-h}$ are dummies that equal 1 when the CEO of firm $i$ has $h$ years remaining on her contract at time $t$, and $\rho_{i}$ are firm fixed effects. That is, we use within-firm variation in turnover probability under different contract horizons, where the base case against which we compare outcomes is a year with less than 1 year under the CEO contract. To capture fluctuations in the economy and the factors that vary over time across industries, such

\footnotetext{
${ }^{6}$ In unreported tests, we verify that turnover rates are equal for each value of CEO tenure from 0 to 4 years. We thank the referee for suggesting this comparison.
} 
as the degree of competition and the supply of CEOs, we control for time in service (tenure) $\boldsymbol{s}_{i t}$ and for year fixed effects $\gamma_{t}$. The dependent variable $\lambda_{i t}$ is turnover, which equals 1 if the CEO leaves in a given firm-year (and set to 0 otherwise).

Initial contract length is set endogenously, as we show in Section 2.2. However, contract length is set ex ante without precise information about future circumstances. Further, once the contract is signed, the number of remaining years changes in a predetermined manner from one year to the next. Contract horizon either decreases by one year, or, upon renewal, it increases sharply. Section 3.1 discussed two features that we rely on to identify the effect of contracts on turnover: first, that most CEO contracts are renewed close to expiration, and second, that many CEOs receive contracts that are of the same length as their previous contracts.

Column 1 in Table 5 reports our results. As the number of years remaining under contract can change within a given fiscal year, we denote them in our tables as "1-2 years remaining", etc. Turnover probability is decreasing in the number of years remaining under contract. CEOs in their second-to-last contract year are 3.9 percentage points less likely to be dismissed as compared to those in the last year before expiration. The difference rises to 11.9 percentage points for CEOs with 5 or more years remaining on their contract. We reject that all of the coefficients on the remaining year dummies are equal to one another at the $1 \%$ level in all specifications.

Linear models avoid the incidental parameters problem that can lead to incorrect estimates of fixed effects in nonlinear models (Neyman and Scott 1948; Heckman 1981). However, linear probability models generate predictions that are outside the $[0,1]$ range, attenuate coefficient estimates towards zero, and are imprecise as compared to hazard models in our context. Therefore, we confirm our results using the proportional hazard model 


$$
\lambda_{i t}=\lambda_{0}\left(\mathrm{~s}_{i t}\right) \mathrm{e}^{\alpha+\sum_{h=1}^{>5} \beta_{h} D_{i t T-h}+r_{i}+\gamma_{t}+\varepsilon_{i t}} .
$$

where $\lambda_{0}$ is the baseline hazard rate that depends on the number of years $s_{i t}$ that the CEO has been in office. Hazard rate $\lambda_{\mathrm{it}}$ captures the likelihood that a CEO leaves the firm $i$ in year $t$, conditional on having served in office until that time. This formulation controls for a non-linear effect of tenure. We use the Cox (1972) partial likelihood model for the baseline hazard, which does not specify a functional form for $\lambda_{0}(\mathrm{~s})$. As such models do not allow for a large number of fixed effects, we replace the firm fixed effects with industry fixed effects $r_{i}$.

Column 2 in Table 5 shows that CEOs with more time remaining to contract expiration are significantly less likely to leave the firm. The odds of turnover for a CEO in her fifth-to-last contracted year are 63 percentage points lower than for a CEO in her last year remaining, conditional on the CEO surviving in office until the given year.

These results are not driven by new CEOs. For CEOs employed under a renewed contract, the estimates (Column 3) are similar in their magnitude and statistical significance. In a test in the next section, we compare renewed CEOs in the year prior to renewal to the year after. To assist the interpretation of these results later, we show that CEOs are significantly more likely to be dismissed in renewal years than in the years following renewal years, by a factor of 3.5. Since this difference follows by construction (as the number of remaining years is reset), we show these estimates only as a basis for later tests, rather than for interpretation on their own.

Selection into contracts of different initial length may affect our results. To mitigate concerns about selection into long vs. short contracts, we split the sample into observations under contracts longer than 3 years and those not longer than 3 years (see Columns 4 and 5 in Table 5). Doing so allows us to examine volatility holding contract length "fixed", up to an approximation. 
The coefficients are larger in magnitude for years under longer contracts (3\%-7\%), but equally significant for short contracts, with the coefficient of $2 \%$ for the horizon of 2-3 years remaining.

Internet Appendix B shows that the turnover-contract horizon results are robust to: (1) controlling for institutional ownership, CEO age, and board composition, (2) using logit models, (3) controlling for CEO, age, and tenure fixed effects, and (4) excluding voluntary turnovers.

\subsection{Contracts and turnover-performance sensitivity}

The relation between distance to contract expiration and CEO turnover probability may reflect a natural managerial life cycle rather than conscious turnover decisions. For long-term contracts to help motivate long-term actions that in the short-term are observationally equivalent to low effort or bad quality, contracts need shield CEOs specifically from turnover after poor performance. To examine this, Column 6 (Table 5) adds to the specification of Column 1 interaction terms of lagged returns and remaining time to contract expiration. In line with our initial observation that contracts shield CEOs from turnover pressure, CEOs have the highest turnover-performance slope in their last year before contract expiration, followed by the year of contract expiration, and the second-to-last year before expiration. The turnover probability of CEOs with 3 or more years left on their contract is not significantly sensitive to past performance. In addition to current performance, boards may consider a longer history of performance. Column 7 (Table 5) shows a similar pattern when measuring performance over the entire tenure period (Jenter and Lewellen 2017), except that the interaction in the year of expiration is insignificant. Tenure performance is defined as the cumulative stock return over the preceding five years or since the start of the current CEO's tenure (whichever is more recent). ${ }^{7}$

\footnotetext{
${ }^{7}$ For this exercise, we use cumulative raw returns and include industry fixed effects instead of cumulative industryadjusted returns. Gormley and Matsa (2014) show that, in settings such as this, the fixed-effects approach is
} 
Finally, contract terms improve the accuracy of turnover prediction. Using the remaining time on the CEO's contract alone produces a higher model fit than the previous literature does using firm size, profitability, dividend payer status, tenure performance, and B/M (Jenter and Lewellen 2017). Moreover, adding contract information to traditional models of CEO turnover results in a meaningful increase of model precision (see Internet Appendix C).

We conclude that the schedule of long-term CEO contracts predicts the timing of turnover. More time remaining under the contract is associated with lower CEO turnover probability as well as a lower sensitivity of CEO turnover to firm performance. The higher rate of turnover closer to contract expiration is potentially consistent with an incentive role of contracts and selection of contract length to match projects of a certain length. However, higher turnover-performance sensitivity is more consistent with the incentive role of contracts than with the selection of contract length. If the main reason to grant the $\mathrm{CEO}$ a contract was to match the duration project she was hired to lead, once the project is completed she will be replaced irrespective of her performance.

\subsection{Career outcomes}

Theoretically, it is also possible that the contract is offset or dwarfed by post-employment career patterns. To show that this is not the case, we explore career outcomes of 874 CEOs after their turnover. ${ }^{8}$ Only 6 CEOs in our sample transition immediately from their old firm to a new one. The scarcity of such transitions indicates that CEO turnover is typically not beneficial for CEOs.

preferable when one seeks to account for industry heterogeneity. We obtain qualitatively and quantitatively similar results using as opposed to industry-adjusted returns.

${ }^{8}$ We use ExecuComp, Bloomberg, LinkedIn, Crunchbase, Wikipedia, SEC filings, news releases by the old and new employers, as well as general media coverage. Whether a new position represents a "promotions" is subjective. To be conservative, we count all non-founder CEO positions and most CFO, COO, president, Managing Director, and similar positions as promotions. 
To further investigate this claim, we expand the definition of promotions to encompass three years after the turnover (as in Brickley, Coles, and Linck 1999) and yield 106 additional promotions. We choose this time horizon following Eckbo, Thorburn and Wang (2016) who study CEO employment outcomes after bankruptcy. While such promotions are arguably better outcomes ex post, a gap of up to 3 years creates substantial uncertainty ex ante in terms of whether the former CEO will be able to find a comparable job. In general, the career outcomes are not great: after turnover, $234 \mathrm{CEO}$ retire without any position, not even an independent directorship.

Subsequent career outcomes are not significantly related to the remaining contract horizon at turnover. Panel A in Table 6 reports summary statistics of the number of cases for different career outcomes, the number of years remaining on the CEO's contract at the time of turnover, and the results of t-tests comparing the number of years remaining for our three different promotion categories to the number of years remaining for CEOs who do not find a better position within 3 years. Consistent with our results on turnover incidence over the contract horizon, most CEOs leave only in the two years before contract expiration. The 6 CEOs who find employment immediately leave with 0.33 years remaining on their contract. The CEOs whom it takes longer to find a new position actually leave earlier rather than later in the contract: with 1.64 years remaining for the CEOs who find a better position within a year, 1.12 years for the CEOs who take 1-3 years to find a better position, and 1.07 years for the CEOs who find no further employment. As the number of years remaining for the best outcome-moving immediately - is quite low and the number of years remaining is considerably higher for the second-best outcome, our evidence is inconclusive. If anything, career outcomes are better if turnover occurs early on in the contract. Panels B and C of Table 6 show in a regression setting 
that there is no significant relation between contract horizon at turnover and subsequent career outcomes. These results validate the idea that, regardless of how many years CEOs have remaining on their contract, career consequences of termination are similarly dire.

\section{Contract horizon and risk}

\subsection{Contract horizon and return volatility}

To analyze the relation between CEO contract horizon and risk, we estimate the model:

$$
y_{i t}=\theta h_{i t}+\rho_{i}+\tilde{\varepsilon}_{i t},
$$

where $y_{i t}$ is the risk of a firm led by CEO $i$ in year $t, h_{i t}$ is contract horizon, and $\rho_{i}$ is a set of CEO fixed effects (or firm fixed effects, in Column 7). That is, we estimate the changes in risk for a given executive as the CEO time horizon changes over the course of the contract.

Table 7 Panel A, Column 1 reveals a strong and significant positive correlation between the number of years remaining on the CEO's contract and return volatility. One additional year remaining on the CEO's contract corresponds to an increase of 3.3 bps in return volatility. The 3.3 bps correspond to $1.9 \%$ of one standard deviation of return volatility.

In Column 2 of Panel A, we examine possible nonlinearities in the relation between the number of years remaining and volatility. We regress volatility on five dummy variables capturing remaining contract times from 1-2 years remaining to over 5 years remaining. The omitted case is less than 1 year remaining. Volatility is significantly higher for CEOs with 2-3 years remaining and for each category longer than 3 years. The rate of increase from one category to the next is lower for the CEOs with longer than 4 years remaining. When a CEO has 3-4 years remaining on her contract, as compared to when she has less than a year remaining, the difference in volatility is $26 \mathrm{bps}$, which equals $15 \%$ of the standard deviation of volatility. 
The economic significance of our results is of similar order of magnitude to those of recent papers examining volatility. Coles, Daniel, and Naveen (2006) find that a one-standarddeviation increase in CEO compensation vega is associated with an increase in volatility equal to $11 \%$ of its standard deviation, or $6 \%$ of its mean. Roussanov and Savor (2014) find that return volatility of firms run by single CEOs is significantly higher than that of firms run by married CEOs. The difference is $3 \%$ of the mean of return volatility. Bernile, Bhagwat, and Rau (2017) show that return volatility of firms whose CEO was exposed to extreme disasters early in her life have lower volatility. The difference in volatility relative to other CEOs is 3.6 percentage points, or $16 \%$ of the standard deviation of volatility, or $10 \%$ of its mean.

Firms in different industries and life cycle points may perceive the unit of one year differently. In Column 3 we measure the time remaining relative to the total length of the contract instead of the number of years remaining. This measure equals $100 \%$ for CEOs with full time remaining under any contract and $0 \%$ for CEOs at expiration of a contract of any length. Our results hold. Moving from the beginning to the mid-point of a contract corresponds to a reduction in volatility of 12 bps.

CEOs whose contracts are renewed offer a second way to test the relation between contract horizon and volatility. The CEO's contract horizon resets upon renewal, whereas timevarying variables, such as tenure and age, and other general or firm-specific trends do not. If it is contract horizon, rather than other time-varying variables, that affects behavior, then risk should also sharply change around renewals. To test this prediction, we define two dummy variables: one for the year when the contract is expiring and up for renewal (renewal year) and the other for the year after the renewal (year after renewal). Since we want to compare only the respective two years around renewals, we do not define these dummies for the first and last year of each CEO in 
our contract sample (new hires, leaving CEOs, as well as the CEOs who previously or subsequently had no fixed-term contract).

Column 4 in Panel A reports the results. Volatility is significantly higher after renewals than it is in renewal years by $26(=15.2+7.8)$ bps. The F-test, reported at the bottom of the table, shows that the difference is significant at the $5 \%$ level. We conclude that our results are not driven by time-varying variables, such as tenure or age, or a downward trend in volatility. Volatility is also lower in renewal years than in other years, although the coefficient itself is not statistically significant. Speculation about CEO succession can increase return volatility close to contract expiration, which can have the opposite of our baseline effect and, therefore, can offset it. However, volatility is significantly higher in the years following renewals than in other years. Column 5 shows that, if we include only renewal years and the years after renewals in our regressions, our results are similar: volatility increases significantly after renewal years. These results are illustrated in Figure 2. We plot estimates of volatility measured as the standard deviation of daily returns (Panel A), and idiosyncratic risk (Panel B) around contract renewals. The graph shows point estimates and $95 \%$ confidence intervals for years around renewals after correcting for firm fixed effects. The top panel shows that volatility decreases slightly (by 7 bps) from 2 years before an renewal year to 1 year prior, but this decrease is not statistically significant. In the year of the renewal, volatility remains similar compared to year -1 .

However, there is a marked and significant increase in volatility in the year after the renewal. Volatility increases by 17 bps relative to year 0 , and 19 bps relative to year -1 . This increase is significant both relative to the renewal year (year 0) and relative to the preceding years. Finally, two years after the renewal, volatility, on average, returns to the level observed in year -2. We document similar patterns for idiosyncratic risk. 
A further advantage of this analysis is that we can directly control not only for CEO fixed effects, but also for tenure, because it is not collinear with our two dummy variables. This allows us to directly measure the learning effect shown by Pan, Wang, and Weisbach (2015) and separate it from the effect of contract horizon. These results are shown in Column 6 in Panel A. Volatility is significantly higher in the years after contract renewals than in renewal years, even after we directly control for tenure. Consistent with Pan, Wang, and Weisbach (2015), we also find that, in general, volatility declines with tenure. Because we use CEO fixed effects in these regressions, controlling for any other variable that changes linearly over time, such as CEO age, yields similar results. Internet Appendix D shows that our results are similar when we replace the linear measure of tenure with the natural logarithm of CEO age. Finally, Column 7 shows the baseline regression with firm fixed effects instead of CEO fixed effects. Our results remain similar: longer time to contract expiration is associated with higher volatility. One additional year remaining on the CEO's contract corresponds to an increase of $3.2 \mathrm{bps}$ in return volatility. The 3.2 bps correspond to $1.8 \%$ of one standard deviation of return volatility.

Panel B of Table 7 provides more information on the magnitude of the volatility effect. We show that the change in volatility from the first to the last year of a CEO's contract is negative: specifically, volatility declines throughout the contract. The average (median) decline in volatility from the first contract year of a CEO to the last is 35 (22) bps. Mirroring the results of our regressions, we see a marked increase in volatility around renewals. From the last year of an initial contract to the first year of a renewed contract (for those CEOs whose contracts are renewed) the mean volatility increase is $43 \mathrm{bps}$ and the median is higher at 55 bps. After that abrupt increase, volatility declines again: from the first year of a renewed contract to 3 years after contract renewal, volatility declines by 51 bps on average ( $25 \mathrm{bps}$ at the median). 
In Columns 1-4 of Table 8, we decompose volatility into systematic risk and idiosyncratic risk, and then re-estimate models 1 and 6 from Table 7 . We find that the documented changes in volatility reflect changes in idiosyncratic risk rather than systematic risk. Hence, the effect we find is not likely to be driven by changes in risk management but rather in firm-specific risk, such as investment projects.

The decreasing pattern of volatility throughout the contract, paired with an increase around contract renewals, are consistent with incentive effects. Our results on CEO turnover imply that contracts affect the timing of turnover and thus provide insurance to the CEO. In line with an incentive role of contracts, they alleviate the threat of being fired for poor performance temporarily at the beginning of the contract. This in turn also makes risk-averse managers more willing to invest projects that have an initial, transient phase of high volatility.

The interpretation of a positive relationship between volatility and time remaining on the contract would be different only if the turnover results do not operate through the incentives channel, but exclusively through the two alternative channels: learning and selection. First, while a declining pattern of volatility throughout the contract is consistent with the learning channel, the observed increases in volatility after contract renewals are difficult to explain in a pure learning model without incentives. Second, the selection argument does not predict a specific relation between time remaining on the contract and volatility. Still, volatility patterns may be influenced by a number of factors, and are likely heterogeneous across firms. Therefore, in Section 5 we provide further evidence suggesting that the relation between time remaining and volatility does not operate only through the learning and the selection channels. 


\subsection{Sources of risk}

In this section, we explore two specific channels that could drive the change in volatility: capital investment and financial leverage. Long-term decisions, while mostly illustrated as investment in theoretical models (e.g., Stein 1989; Von Thadden 1995), may also take other forms such as hiring specific managers or shifting resources between business units. However, such actions are more difficult to observe empirically. Columns 5-6 in Table 8 show a positive association between remaining years and capital expenditures (normalized by lagged total assets). Compared to years in which the CEO has less than one year remaining on her contract, capital investment is 1.4 bps (or $15 \%$ of one standard deviation) higher than when the CEO has 3-4 years remaining. Similarly to our findings for volatility, we also find that capital expenditures increase once the CEO's contract is renewed, relative to the year before (i.e. the renewal year). The F-tests indicate that difference is highly statistically significant.

Columns 7-8 in Table 8 show a positive relation between remaining years and financial leverage. Columns 7 reveals a significant positive correlation between these two factors. The economic significance of these effects is also smaller than for investment. The results using contract renewals in Columns 8 are less robust than those found for capital expenditure. Overall, the results show that a longer time to contract expiration is associated with a higher investment. The effect on leverage is also positive, but weaker both economically and statistically.

Overall, these results on the sources of risk provide further evidence consistent with the incentive role of contracts. Both idiosyncratic risk and capital expenditures follow the same pattern as volatility: they decline over the course of the contract, and increase after contract renewals. These patterns suggest that the CEO actively takes on projects with a transient volatility phase early on in her contract. 


\subsection{Robustness of the relation between contract horizon and volatility}

Compensation. Starting with Holmstrom (1982), the literature has argued that firms need to provide compensation packages that incentivize risk taking and thereby offset the effect of career concerns. Several papers provide evidence that certain types of compensation (e.g. options) are indeed able to induce risk taking (e.g. Agrawal and Mandelker 1987; DeFusco, Johnson, and Zorn 1990; Guay 1999; Coles, Daniel, and Naveen 2006; Low 2009; Chava and Purnanandam 2010; Hayes, Lemmon, and Qiu 2012; Gormley, Matsa, and Milbourn 2013; Shue and Townsend 2017). Option vesting periods induce incentives that vary over time (Ladika and Sautner 2013; Edmans, Fang, and Lewellen 2017; Gopalan et al. 2014). Such time-varying compensation incentives may explain our results.

To disentangle the effects of career concerns and compensation, we add the following control variables to our main regression: the level of compensation (log of TDC1, the sum of cash compensation and equity compensation granted in that year); the sensitivity of the CEO's unvested and vested portfolio of stock and options to stock returns (stock price sensitivity); and the sensitivity of that portfolio to stock return volatility (vega). These sensitivities are computed using Core and Guay's (2002) methodology. These variables are from ExecuComp, which has data for 3,348 observations in our sample. To retain observations with missing values, we add a dummy for missing compensation and set the compensation values to the sample average.

The results are shown in Table 9. Our results hold when we control for compensation. The magnitude of the coefficient estimate is slightly reduced (0.029 compared to 0.033 in Table 7 Panel A), but it is significant across all specifications. To ensure that our tests are comparable to previous literature, we estimate the model specification of Coles, Daniel, and Naveen (2006). 
Controlling for Coles, Daniel, and Naveen's (2006) set of variables yields similar results. Overall, we conclude that compensation cannot explain our baseline results.

Excluding the first year of each CEO. Including each CEO's first year in the sample may be problematic because a CEO's starting date rarely coincides with the fiscal year end. Hence, the first fiscal year of a new CEO is likely to contain days under the former CEO. To ensure that our results are not driven by CEOs' first years in office, we discard all firm-years that correspond to a CEO's first year of employment in that position (1,398 observations, or 19\%). The results, reported in Table 9 Column 4, are actually stronger than the baseline regression.

CEO and firm age. Because we use CEO fixed effects in all our main regressions, controlling for tenure (see Column 6 in Table 7 Panel A, and Columns 2, 4, 6 and 8 in Table 8) yields similar results to controlling for any variables that change linearly over time, including age. However, the effect of CEO age on firm outcomes may decrease over time. In addition, the firm's history and position in its life cycle may exhibit a predictable time trend. For example, firms may become less risky over time as they accumulate assets, equity, and expertise. As renewals constitute an "off-trend" jump in the remaining years under contract that does not commove with time, we can use this setting to distinguish the effects of CEO age from the contract. In Table 9 Column 5 we use the renewal setting and include the natural logarithm of CEO age as a control variable. In Column 6, we control for firm age ranges based on recent work by Arikan and Stulz (2016) Controlling for age does not explain our results: volatility after contract renewals is still significantly higher than in renewal years. In unreported analyses, we also find that the results remain unchanged for capital expenditures and leverage as well.

Lags between decisions and volatility. A spurious relation between contract horizon and risk can emerge if there are systematic lags between investment decisions and volatility 
increases. It is unlikely that the existence of such lags biases our results for two reasons. First, the relation between contract horizon and both volatility (Table 7), and capital expenditures and leverage (Table 8), shows the same pattern both in the linear specification and for renewals. If capital expenditures or leverage take longer to be incorporated into stock prices, they should follow different patterns. Second, we follow the methodology of Hall et al. (1986) and estimate the average lag per Fama-French 49 industry between R\&D expenditures and information availability about innovation output as measured by patent applications. Using this information, we rerun our main regressions from Table 7, Panel A discarding industries that have a lag of 3 years (the longest lag), 2-3 years, or 1-3 years. Both the statistical and the economic significance of our results increases as we discard observations with lags. These results are untabulated.

Renewals prior to contract expiration. Table 2 Panels C and D show that most contracts in our sample are renewed at or close to their expiration. Renewing contracts much before their expiration implies that at any point in time, there are not two, but three options that the board may consider: (i) firing the $\mathrm{CEO}$, (ii) retaining the $\mathrm{CEO}$ without offering a renewal, and (iii) retaining the CEO and offering a renewal. If investors are aware that both the second and the third options are available to the board, they should update their information when observing CEO retention without renewal for an extended period of time. This most likely increases uncertainty about CEO turnover and therefore corporate policies, leading to an increase in volatility over the course of the contract in cases where the CEO is retained without renewal. This effect would work in the opposite direction compared to the patterns we show in the paper.

CEO and firm survival. Although CEO contract length is predetermined, the decision to replace (or not) the CEO at the end of the contract cycle is endogenous and, therefore, could be related to the investment and volatility patterns that we document. To ease the concern that our 
results are driven only by CEOs whose contracts are (later) renewed and not by those whose are not, we re-estimate our baseline specifications for the subsample of CEO contracts that are not (eventually) renewed. The results of these regressions, shown in Columns 1-2 in Table 10, are similar to our baseline results. Further, endogenous firm (non-)survival may also bias our results if some CEOs pursue a particular strategy to maximize the probability of an acquisition, and this strategy produces a volatility pattern different from what we observe. We verify that our results hold if we exclude firms that exit the sample because they are acquired, or for other reasons related to firm performance. These results are unreported for brevity. We conclude that neither CEO nor firm survival has a major effect on our results.

Long vs. short contracts. Another potential concern is that our results may be driven by firms with longer CEO contracts, which are the only ones that have observations with a higher number of years remaining under contract. To alleviate this concern, in Columns 3-6 in Table 10, we split the sample into CEOs with contracts longer than three years and those with contracts of at most three years. Our results hold in both subsamples. The two coefficients are not statistically different from each other, suggesting that our results are not driven by differences between these two samples. In unreported tests we find similar results for idiosyncratic risk.

Selection into the sample. Because all of our results are estimated with CEO fixed effects, they are valid within the sample of CEOs with fixed-term contracts, a non-trivial percentage of firms within the S\&P 500 (see also Gillan et al., 2009). In additional tests, we use variation in the legal treatment of employment contracts to show that selection into the sample of fixed-term contracts does not have a material effect on our results (Internet Appendix F). 


\section{Channels}

\subsection{Sample splits}

To provide evidence suggestive of career concerns, we investigate whether our results are stronger in those subsamples where the different theoretical explanations predict them to be.

Our results should be stronger in cases where CEOs have greater career concerns. One relevant example is CEOs far from retirement. Indeed, Jenter and Lewellen (2015) show that CEOs just over the common retirement threshold of 65 years of age are more likely to agree to a sale of their firms. Therefore, we expect that these CEOs would be less concerned about their future career, and thus spread risk-taking initiatives evenly instead of avoiding them at the end of the contract. We verify that older CEOs and specifically those aged over 65 face a lower renewal probability - these results are unreported for brevity. By contrast, there is less reason to expect technological cycles to be less prevalent for firms with old CEOs. In conclusion, we expect the effect of career concerns to be stronger for younger CEOs.

Our results are prevalent only for young CEOs. In Column 1 of Table 11, we interact our main variables with a dummy variable for CEOs under and over 65 years of age. Volatility is significantly related to contract horizon only for CEOs aged under 65. While the statistical insignificance of the coefficient for CEOs aged over 65 may be related to the smaller size of the subsample (756 observations, or $10 \%$ of our sample), the coefficient is also much smaller, 0.010 as compared to 0.042 for younger CEOs. Since the average contract length is three years, our results should hold for age thresholds starting from 62 years. We confirm this in Column 2. 
As further evidence that our results are weaker for CEOs with lower career concerns, we examine founders and CEOs with a higher tenure. Columns 3-4 show that our results are present only for non-founder CEOs and low-tenure CEOs (tenure below 5 years). ${ }^{9}$

Next, selection effects are likely to be weaker than treatment effects in those firms where it may be more difficult to predict the length of technological or managerial cycles. As contract horizon is set ex ante, variables unrelated to the contract that explain our results should be predictable by boards: otherwise, it is unlikely that their effects on volatility over time coincide with the contract horizon. One relevant example is fast-moving industries. In such industries, it may be difficult to predict the length of technological cycles ex ante and, therefore, problematic to set a fixed term for a contract that coincides with volatility later. Therefore, we expect selection effects to be weaker in such industries.

We provide evidence against the hypothesis that selection effects drive our results using the product market fluidity measure developed by Hoberg, Phillips, and Prabhala (2014). ${ }^{10}$ We split the sample by the annual median product market fluidity. Column 5 of Table 11 shows that the coefficient for the number of remaining years is indeed higher (albeit not significantly) for firms with high product market fluidity. The results are very similar when we interact fluidity with the all other measures related to contract horizon that we use in the paper. On balance, while the relation between the number of years remaining and volatility is stronger in more dynamic industries, this difference does not reach statistical significance.

\footnotetext{
${ }^{9}$ Our cutoff of 5 years is motivated by Pan, Wang, and Weisbach's (2015) showing that the market learns about CEO ability and fit during the first 5 years. Our results are robust to using a cutoff value of 8 or 10 years instead. 10 These data are available at http://hobergphillips.usc.edu/.
} 


\subsection{Volatility patterns in firms without fixed-term contracts}

The results above are consistent with the prediction that CEOs adopt corporate policies in response to contractual protection. Yet, it is possible that $\mathrm{CEO}$ contract cycles are correlated with investment opportunities. New CEOs may be hired at times of unusually good or bad investment opportunities, which later revert to the mean. Boards may choose to coordinate the length of CEO employment contracts with natural technological cycles to set a planning horizon for the entire firm. In turn, such a commitment to the CEO and her projects may incentivize employees to work on uncertain projects without fearing a reversal by the next CEO and help the firm attract talent for the new projects (Rotemberg and Saloner 2000; Van der Steen 2005, 2016).

If it is not the contract that causes the relation between contract horizon and volatility, but rather technological cycles or the board's decision to evaluate and keep the CEO precisely when a volatility cycle has completed, we should see similar volatility cycles also in the absence of fixed-term contracts. Therefore, we use CEOs without fixed-term contracts to identify noncausal cycles related to hiring and renewal decisions. We use three different tests in this setting.

First, we show that plausible sources of risk cycles (cycles in investment, demand, or asset duration) are not correlated with volatility in firms whose CEOs are employed at will. As described in Section 2.2, the average cycles are longer than the average CEO contract. For each firm-year, we compute the number of years left until the end of the cycle. As Panel A of Table 12 shows, the average difference between this variable and the number of years remaining to the expiration of the CEO's contract is 1.01 for CAPEX cycles, 1.27 for sales cycles, and 1.20 for depreciation cycles. The large difference between these cycles and the contract horizon indicates that these cycles do not always coincide with contract cycles. 
Panel B in Table 12 shows a regression of volatility on the number of years remaining in the technological cycle and CEO fixed effects. ${ }^{11}$ The number of years remaining in a technological cycle is either negatively correlated with volatility, or shows no significant relation to volatility. Thus, the relation between technological cycles and volatility is different for firms without contracts, contradicting the prediction that technological cycles cause volatility, which should be true even in the absence of contracts.

Second, we test for abrupt increases in volatility around the end of firm-specific evaluation cycles. Since we do not observe performance evaluations similar to "renewals" in the absence of contracts, we use a noisy outside measure, significant raises in compensation. Gao, Harford and Li (2012) show that cuts in CEO compensation predict turnover and interpret it as a vote of no confidence. If significant pay changes indicate board evaluation events, compensation raises should also indicate a vote of confidence. In our baseline sample of CEOs with fixed-term contracts, contract renewals are followed by on average $15 \%$ increase in compensation, indicating that evaluations indeed coincide with raises. Indeed, $44 \%$ of compensation raises over $15 \%$ in the firms with fixed-term contracts take place just after renewals.

If purely technological reasons drive our results, we should observe similar patterns around evaluations of CEOs without fixed-term contracts. Panel C in Table 12 shows that this is not the case. On the contrary, CEOs without fixed-term contracts are associated with more volatility (Columns 1 and 2), idiosyncratic risk (Columns 5 and 6), but not systematic risk (Columns 3 and 4), and investment just before, not after evaluations. The difference between the year before and after the evaluation is not significant. These results are robust to controlling for tenure and age. Hence, to the extent that, similarly to the contract renewal for fixed-term CEOs,

\footnotetext{
${ }^{11}$ To guard against the concern that we correctly measure the length of technological cycles, but miss their timing by a year, we also use the lag or the lead of the number of remaining years in the cycle, and find similar results. These tests are unreported.
} 
compensation raises to CEOs without such contracts are a good measure of evaluations, we do not observe abrupt increases in volatility around these events.

Third, raises in compensation may occur for reasons other than evaluations, so they may not provide an accurate enough measure of the timing of a firm-specific cycle. If a large increase in volatility indicates the start of a firm-specific cycle, then also firms without fixed-term contracts should exhibit these cyclical volatility patterns. Thus, we now explicitly choose firms (without fixed-term contracts) with large volatility increases and test whether volatility follows a predictable pattern of decline after a spike, similarly to our results for fixed-term contracts. As a cutoff, we use the 20bps rise in volatility around renewals from our baseline results in Table 7. To find the most likely cycle length for a firm without a fixed-term contract, we employ a matching procedure: we match each firm without a fixed-term contract and with a volatility peak to another firm whose $\mathrm{CEO}$ is employed under a fixed-term contract and has similar characteristics. We then use the contract length of the fixed-term CEO as the predicted length of the technological cycle for the firm without a fixed-term CEO contract. Internet Appendix G provides more detail on the details of the matching procedure.

Panel D in Table 12 shows the results. Column 1 contains results after matching without requiring an exact match on industry, and Column 2 shows the results if we require an exact match on industry. We find no significant relation between the number of remaining years in the technological cycle estimated using similar firms with fixed-term contracts in any of our specifications. Using this alternative method to infer the timing of technological cycles, we again conclude that, unlike for CEOs employed under fixed-term contracts, volatility does not exhibit the same significant positive correlation with time remaining under contract (time remaining in the cycle) for CEOs employed at will. In Columns 3-4, we combine the matching procedure with 
the compensation raises: We use raises in compensation to define the start of the cycle for at-will CEOs and proceed with the matching as specified above. Again, we find that the number of years remaining in the cycle is not significantly related to volatility. ${ }^{12}$

\subsection{Magnitudes in terms of CEO turnover probability}

Our results suggest that insurance against early turnover is one of the channels through which contracts affect volatility. In Internet Appendix E, we focus on this channel and estimate magnitudes in a two-stage least squares model using contract horizon as a predictor for turnover probability in the first stage. Alternatively, we use a Cox hazard model of CEO turnover. ${ }^{13}$

The values in Table A-7, Panel A, Column 1 indicate that an increase of one standard deviation in turnover probability corresponds to a reduction of 31 basis points (bp) in return volatility. The 31 basis points correspond to $18 \%$ of one standard deviation in return volatility. An increase of one standard deviation in turnover probability corresponds to a 36-bp decrease in idiosyncratic risk (which is $20 \%$ of one standard deviation of idiosyncratic risk). The contract horizon variables are sufficiently strong instruments. We report the first-stage F-statistic at the bottom of Panel A. The value of 32.11 far exceeds the conventional cutoff of 10, and also exceeds the 5\% critical values given by Stock and Yogo (2005) for various levels of 2SLS bias relative to OLS. Thus, the bias of our estimates is below 5\%. Economic magnitudes are similar when we use the Cox hazard model. See Internet Appendix E for a more detailed discussion.

\footnotetext{
${ }^{12}$ Firms may have multiple volatility or compensation cycles over time. We obtain similar results if instead of using the average cycle length we use the median cycle length or the length of only the first observed cycle for each firm. These results are unreported for brevity.

${ }^{13}$ In this case, we apply the correction of Murphy and Topel (1985) to the standard errors in the second stage.
} 


\section{Conclusion}

This paper studies the link between CEO contract horizon and volatility. We introduce novel data on the length of CEO employment contracts in the US and document several stylized facts about them. The time remaining under contract is a strong predictor of CEO turnover. Both turnover probability and turnover-performance sensitivity increase over the course of the contract as it approaches expiration. Contract horizon is related to firm outcomes: stock return volatility, especially the idiosyncratic component, capital expenditures, and, to a lesser extent, leverage are higher at the beginning of the contract. At renewals, when the contract horizon is reset, all these outcome variables sharply increase, suggesting that our results are not driven by other life cycle variables, such as CEO or firm age, tenure, or general time trends.

Consistent with optimal contracting, we show that firms and CEOs enter into longer contracts in situations where a longer contract is more useful, indicating that firms may use longterm contracts as an instrument to set incentives. In line with this argument, we find that the positive horizon-volatility relationship is more pronounced where such incentives are more likely to be effective: with younger CEOs, CEOs with shorter tenure, and CEOs who are not the founder of the firm.

Stock-based compensation introduces convexity in CEO incentives and therefore allows the CEO to benefit from the upside of risky strategies. However, while such stock-based compensation may incentivize CEOs to pursue projects with a significant upside, it is not clear how much they help with projects with a considerable downside. As Jenter and Lewellen (2014) show, turnover-performance sensitivity is asymmetric. Traditional equity compensation instruments are therefore a costly means to help the risk-averse CEO overcome the worries that 
prevent from taking projects with downside risk (Holmstrom 1982, Manso 2016). Our work highlights that contracts provide such insurance to downside risk.

Our work highlights direct (CEO turnover) and indirect consequences (volatility) of contract terms. Overall, our results point to contract length as an important element in the CEO contract design. Boards as well as regulators should take incentive consequences into account if they consider changing contract terms or regulations regarding executive employment contracts. Finally, our paper suggests that boards and CEOs set contract length with a purpose. This implies that many firms have a long-term horizon that goes beyond the daily stock return and quarterly earnings. 


\section{References}

Acemoglu, D., Akcigit, U., and M. A. Celik. 2014. Young, restless and creative: Openness to disruption and creative innovations. National Bureau of Economic Research Working Paper, No. w19894.

Aghion, P. and M.O. Jackson. 2016. Inducing leaders to take risky decisions: dismissal, tenure, and term limits. American Economic Journal: Microeconomics 8: 1-38.

Agrawal, A., and G. Mandelker. 1987. Managerial incentives and corporate investment and financing decisions. Journal of Finance 42: 823-837.

Alesina, A., N. Roubini, and G. D. Cohen. 1993. Political Cycles and the Macroeconomy. Cambridge, Massachusetts: MIT Press.

Anderson, R., M. C. Bustamante, S. Guibaud, and M. Zervos. 2018. Agency, firm growth and managerial turnover. Journal of Finance 73: 41--464

Antia, M., Pantzalis, C., and J. C. Park. 2010. CEO decision horizon and firm performance: An empirical investigation. Journal of Corporate Finance 16: 288-301.

Arikan A. M. and R. M. Stulz. 2016. Corporate acquisitions, diversification, and the firm's life cycle. Journal of Finance 71: 139-194.

Bernile, G., Bhagwat, V., and P.R. Rau. 2017. What doesn't kill you will only make you more risk-loving: Early-life disasters and CEO behavior. Journal of Finance 72: 167-206.

Bolton, P., Scheinkman, J. and Xiong, W. 2006. Executive compensation and short-termist behaviour in speculative markets. Review of Economic Studies 73: 577-610.

Brickley, J. A., J. L. Coles, and J. S. Linck. 1999. What happens to CEOs after they retire? New evidence on career concerns, horizon problems, and CEO incentives. Journal of Financial Economics 52: 341-377.

Cassell, C. A, Huang, S. X., Sanchez, J. M., and M. D. Stuart, 2012. Seeking safety: The relation between CEO inside debt holdings and the riskiness of firm investment and financial policies. Journal of Financial Economics 103: 588-610.

Chava, S., and A. Purnanandam. 2010. CEOs versus CFOs: incentives and corporate policies. Journal of Financial Economics 97: 263-278.

Chevalier, J., and G. Ellison. 1997. Risk taking by mutual funds as a response to incentives. Journal of Political Economy 105: 1176-1220.

Clayton, M., J. Hartzell, and J. Rosenberg. 2005. The impact of CEO turnover on equity volatility. Journal of Business 78: 1779-1808.

Coles, J. L., N. D. Daniel, and L. Naveen. 2006. Managerial incentives and risk taking. Journal of Financial Economics 79: 431-468.

Core, J., and W. Guay. 2002. Estimating the value of employee stock option portfolios and their sensitivities to price and volatility. Journal of Accounting Research 40: 613-630.

Cox, D. R. 1972. Regression models and life tables. Journal of the Royal Statistical Society, Series B 34: 187-220.

Custodio, C., Ferreira, M.A., and Matos, P., 2013. Generalists versus specialists: Lifetime work experience and chief executive officer pay. Journal of Financial Economics 108(2): 471-492.

Dahiya, S., and D. Yermack. 2008. You can't take it with you: Sunset provisions for equity compensation when managers retire, resign, or die. Journal of Corporate Finance 14: 499-511. 
DeFusco, R. A., R. R. Johnson, and T. S. Zorn. 1990. The effect of executive stock option plans on stockholders and bondholders. Journal of Finance 45: 617-627.

Eckbo, E., K. Thorburn, and W. Wang. 2016. How costly is corporate bankruptcy for top executives? Journal of Financial Economics 121: 210-229.

Edmans, A., and Liu, Q. 2011. Inside debt. Review of Finance

Edmans, A., V. Fang, and K. Lewellen. 2017. Equity vesting and investment. Review of Financial Studies 30: 2229-2271.

Fos, S., and M. Tsoutsoura. 2014. Shareholder democracy in play: Career consequences of proxy contests. Journal of Financial Economics 114: 316-340.

Gabaix, X., and Landier, A., 2008. Why has CEO pay increased so much? Quarterly Journal of Economics 123(1): 49-100.

Gao, H., J. Harford, and K. Li. 2012. CEOs pay cuts and forced turnover: Their causes and consequences. Journal of Corporate Finance 18: 291-310.

Garfinkel, J., J. Kim, and K. Lee. 2013. The interactive influence of external and internal governance on risk taking and outcomes: the importance of CEO career concerns. Working paper, University of Iowa.

Gayle, G.L., Golan, L., and Miller, R.A., 2015. Promotion, turnover, and compensation in the executive labor market. Econometrica 83: 2293-2369.

Gibbons, R., and K. J. Murphy. 1992. Optimal incentive contracts in the presence of career concerns: Theory and evidence. Journal of Political Economy 100: 468-505.

Gillan, S. L., J. C. Hartzell, and R. Parrino. 2009. Explicit vs. implicit contracts: evidence from CEO employment agreements. Journal of Finance 64: 1629-1655.

Goel, A. M., and A. V. Thakor. 2008. Overconfidence, CEO selection, and corporate governance. Journal of Finance 63: 2737-2784.

Goldman, E., and P. Huang. 2015. Contractual versus actual severance pay following CEO departure. Management Science 61: 1108-1120.

Gopalan, R., T. T. Milbourn, F. Song, and A. V. Thakor. 2014. Duration of executive compensation. Journal of Finance 69, 2777-2817.

Gormley, T. A., and D. A. Matsa. 2011. Growing out of trouble? Corporate responses to liability risk. Review of Financial Studies 24: 2781-2821.

Gormley, T. A., and D. A. Matsa. 2014. Common errors: How to (and not to) control for unobserved heterogeneity. Review of Financial Studies 27(2): 617-661.

Gormley, T. A., and D. A. Matsa. 2016. Playing it safe? Managerial preferences, risk, and agency conflicts. Journal of Financial Economics 122: 431-455.

Gormley, T. A., D. A. Matsa, and T. T. Milbourn. 2013. CEO compensation and corporate risk: Evidence from a natural experiment. Journal of Accounting and Economics 56: 79-101.

Gryglewicz, S., S. Mayer, and E. Morellec. 2018. Agency conflicts and short- vs long-termism in corporate policies, Working paper, Erasmus University Rotterdam.

Guay, W. R. 1999. The sensitivity of CEO wealth to equity risk: An analysis of the magnitude and determinants. Journal of Financial Economics 53: 43-71.

Hall, B. J., Z. Griliches, and J. A. Hausman. 1986. Patents and R\&D is there a lag? International Economic Review 27: 265-283.

Hayes, R. M., M. Lemmon, and M. Qiu. 2012. Stock options and managerial incentives for risk taking: Evidence from FAS 123R. Journal of Financial Economics 105: 174-190.

Heckman, J. J. 1981. The Incidental Parameters Problem and the Problem of Initial Conditions in Estimating a Discrete Time-Discrete Data Stochastic Process. In Structural Analysis of 
Discrete Data with Econometric Applications, edited by Charles Manski and Daniel McFadden, 179-195. Cambridge: MIT Press.

Hoberg, G., G. Phillips, and N. Prabhala. 2014. Product market threats, payouts, and financial flexibility. Journal of Finance 69: 293-324.

Holmstrom, B. 1982. Managerial incentive problems: a dynamic perspective. In Essays in Economics and Management in Honor of Lars Wahlbeck. Helsinki: Swedish School of Economics. (Published in Review of Economic Studies (1999) 66: 169-182).

Holmstrom, B., and J. Ricart i Costa. 1986. Managerial incentives and capital management. Quarterly Journal of Economics 101: 835-860.

Huang, J., C. Sialm, and H. Zhang. 2011. Risk shifting and mutual fund performance. Review of Financial Studies 24: 2575-2616.

Jensen, M., and W. H. Meckling. 1976. Theory of the firm: managerial behaviour, agency costs and ownership structure. Journal of Financial Economics 3: 305-360.

Jenter, D., and F. Kanaan. 2015. CEO turnover and relative performance evaluation. Journal of Finance 70: 2155-2184.

Jenter, D., and K. Lewellen. 2017. Performance-induced CEO turnover. Working paper, London School of Economics.

Jenter, D., and K. Lewellen. 2015. CEO preferences and acquisitions. Journal of Finance 70: 2813-2852.

Kaplan, S. N., and B. A. Minton. 2012. How has CEO turnover changed? International Review of Finance 12: 57-87.

Kempf, A., S. Ruenzi, and T. Thiele. 2009. Employment risk, compensation incentives, and managerial risk taking: Evidence from the mutual fund industry. Journal of Financial Economics 92: 91-108.

Knoeber, C. R. 1986. Golden parachutes, shark repellents, and hostile tender offers. American Economic Review 76: 155-167.

Ladika, T., and Z. Sautner. 2018. The effect of managerial short-termism on corporate investment. Working paper, University of Amsterdam.

Lee, J., Park, J., and T. Folta. 2018. CEO career horizon, corporate governance, and real ptions: The role of economic short-termism. Strategic Management Journal, Forthcoming.

Lipton, M. 1987. Corporate governance in the age of finance corporatism. University of Pennsylvania Law Review 136: 1-72.

Low, A. 2009. Managerial risk-taking behaviour and equity-based compensation. Journal of Financial Economics 92: 470-490.

Matta, E. and P. W. Beamish. 2008. The accentuated CEO career horizon problem: evidence from international acquisitions. Strategic Management Journal 29: 683-700.

Murphy, K. M., and R. H. Topel. 1985. Estimation and inference in two-step econometric models. Journal of Business and Economic Statistics 3: 88-97.

Murphy, K. J., and Zimmerman, J. L. 1993. Financial performance surrounding CEO turnover, Journal of Accounting and Economics 16: 273-315.

Neyman, J., and E. L. Scott. 1948. Consistent estimates based on partially consistent observations, Econometrica 16: 1-32.

Pan, Y., T. Y. Wang, and M. S. Weisbach. 2015. Learning about CEO ability and stock return volatility, Review of Financial Studies 28, 1623-1666.

Pan, Y., T. Y. Wang, and M. S. Weisbach. 2016. CEO investment cycles. Review of Financial Studies 29: 2955-2999. 
Parrino, R. 1997. CEO turnover and outside succession a cross-sectional analysis. Journal of Financial Economics 46: 165-197.

Rau, R., and J. Xu. 2013. How do ex-ante severance pay contracts fit into optimal executive incentive schemes? Journal of Accounting Research 51: 631-671.

Rotemberg, J. J., and G. Saloner. 2000. Visionaries, managers, and strategic direction. Rand Journal of Economics 31: 693-716.

Rusticus, T. O. 2006. Executive severance agreements. Working paper, University of Pennsylvania.

Schwab, S. J., and R. T. Thomas. 2005. What do CEOs bargain for? Washington and Lee Law Review 63: 231-270.

Shleifer, A., and R.W. Vishny. 1997. The limits of arbitrage. Journal of Finance 51: 35-55

Shue, K., and R. Townsend. 2017. How do Quasi-Random Option Grants Affect CEO RiskTaking? Journal of Finance, Forthcoming.

Stein, J. C.. 1989. Efficient capital markets, inefficient firms: A model of myopic corporate behavior. Quarterly Journal of Economics 104(4): 655-669.

Stock, J. H., and M. Yogo. 2005. Testing for Weak Instruments in Linear IV Regression. In Identification and Inference for Econometric Models: Essays in Honor of Thomas Rothenberg, edited by Donald W. K. Andrews and James H. Stock, 80-108. Cambridge: Cambridge University Press.

Sundaram, R. and Yermack, D. 2007. Pay me later: inside debt and its role in managerial compensation. Journal of Finance 62: 1551-1588.

Tervio, M. 2008. The difference that CEOs make: An assignment model approach. American Economic Review 98(3): 642-668

Tirole, J. 2006. The theory of corporate finance. Princeton University Press.

Van der Steen, E. 2005. Organizational beliefs and managerial vision. Journal of Law, Economics, and Organization 21: 256-283.

Van der Steen, E. 2016. Strategy and the strategist: How it matters who develops the strategy. Management Science, Forthcoming.

Vladimirov, V. 2017. Contract horizon and turnover. Working paper, University of Amsterdam.

Von Thadden, E-L. 1995. Long-term contracts, short-term investment and monitoring. Review of Economic Studies 62: 557-575

Warner, J. B., R. L. Watts, and K. H. Wruck. 1988. Stock prices and top management changes. Journal of Financial Economics 20: 461-492.

Weisbach, M., 1988. Outside directors and CEO turnover. Journal of Financial Economics 20: 431-460. 


\section{Figure 1: Turnover probability by $\mathrm{CEO}$ tenure and by $\mathrm{CEO}$ age}

The top graph shows CEO turnover probability as a function of CEO tenure, separately for short contracts (length of maximum three years), long contracts (length exceeding three years), and at-will contracts. Tenure $=0$ denotes CEOs in their first year who have not completed one year of service. The bottom graph shows a local polynomial regression of turnover probability on age for CEOs under a fixed-term contract using an Epanechikov kernel and a bandwidth of 1 year. The area around the local polynomial regression curve shows the $95 \%$ confidence interval.
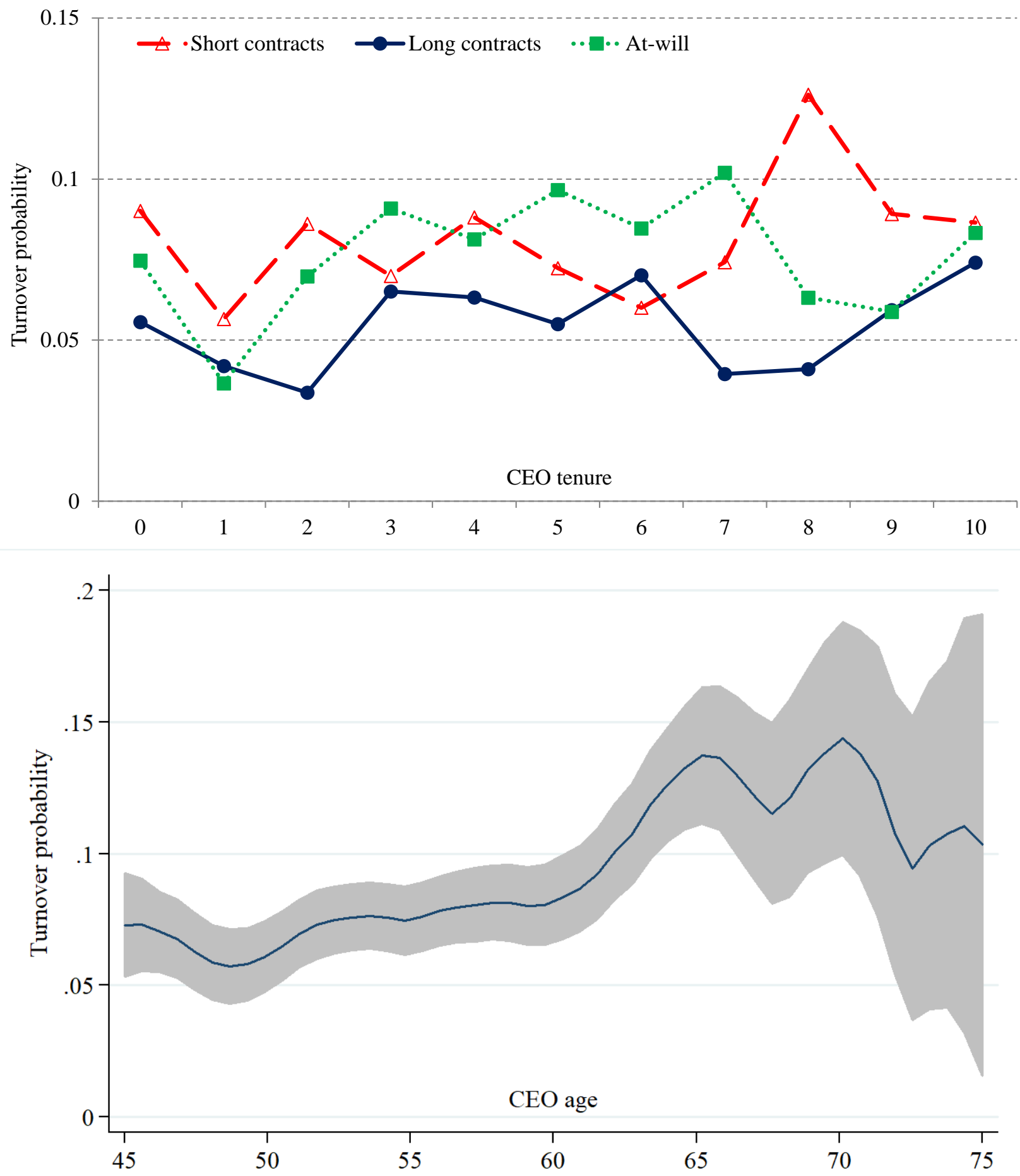

kernel $=$ epanechnikov, degree $=0$, bandwidth $=1$, pwidth $=2.93$ 


\section{Figure 2: Changes in volatility and idiosyncratic risk around contract renewals}

Panel A shows residuals from a regression of volatility on CEO fixed effects for CEOs whose contracts are renewed in the years around the renewal. The horizontal axis measures event time in years around the renewal. Year 0 is the year of the renewal. The vertical axis measures volatility in percentage points. The circles represent the average of the residuals and the bars show the upper and lower end of the 95\% confidence interval. Panel B shows similar estimates for idiosyncratic risk. Volatility and idiosyncratic risk are defined in Appendix A.

Panel A: Volatility around renewals

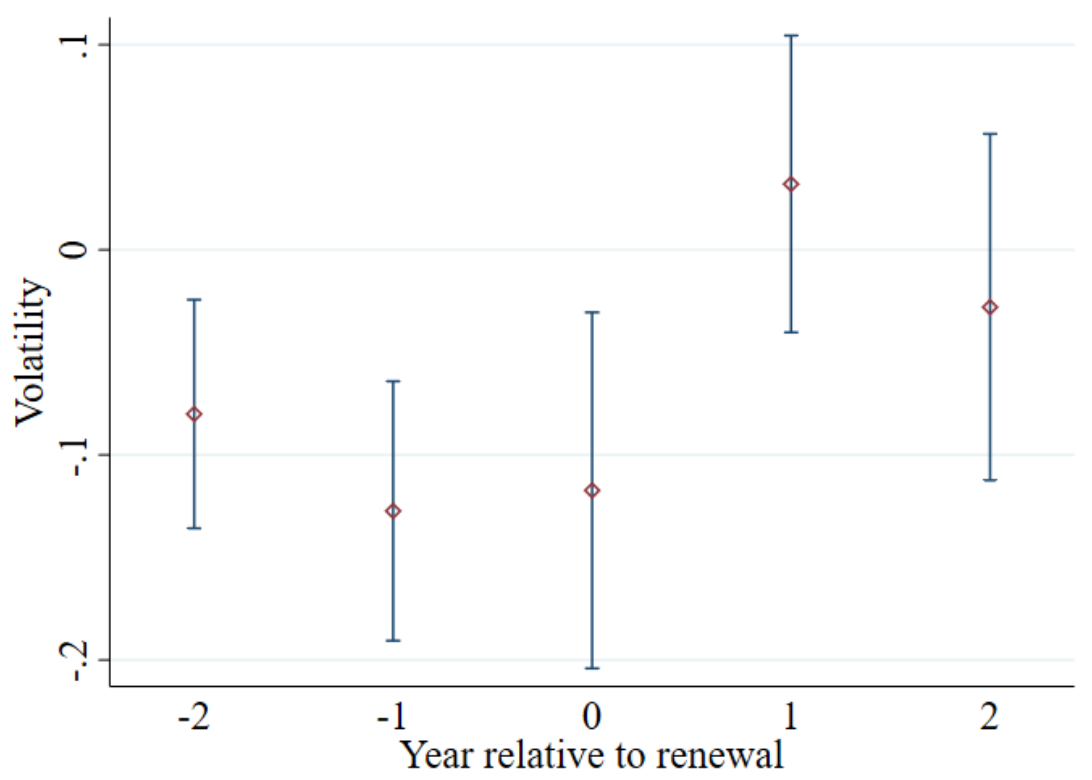

Panel B: Idiosyncratic risk around renewals

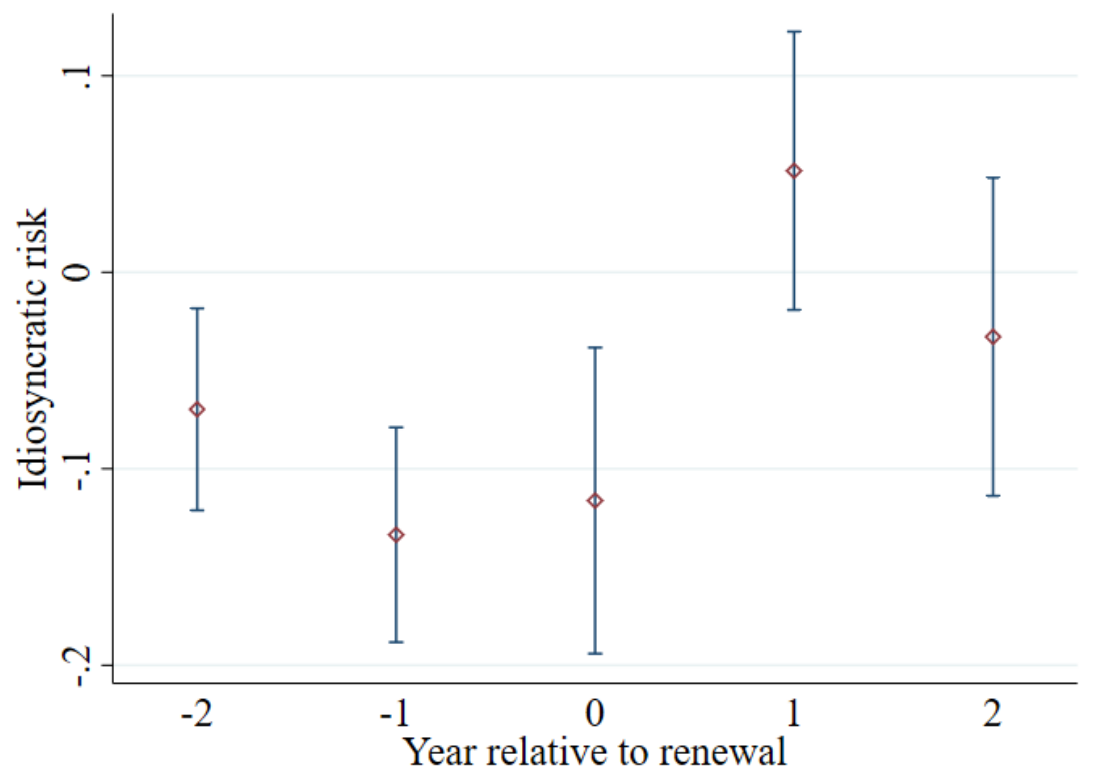




\section{Table 1: Summary statistics}

This table presents descriptive statistics of our sample of contracts. Information on contracts is hand-collected from SEC filings for the period of 1992-2008. Panel A shows the number of observations by contract length. Panel B shows summary statistics for firm characteristics at the start of the contract for our entire sample of fixed-term contracts (Column 1), fixed-term contracts separated by length (Columns 3-7), and the sample of at-will contracts that we use for the matching analysis (Column 2). Panel C shows summary statistics for all firm-year observations in our sample of fixed-term contracts, separating observations of new and renewed CEOs in Columns 7 and 8. Variables are defined in Appendix A. All non-discrete variables are Winsorized at the $1 \%$ level.

\begin{tabular}{|c|c|c|c|c|c|c|c|c|c|c|c|c|c|c|}
\hline \multicolumn{15}{|c|}{ Panel A: Contract length } \\
\hline Length (years) & $<1$ & 1 & 2 & 3 & 4 & 5 & 6 & 7 & 8 & 9 & 10 & $>10$ & \multicolumn{2}{|c|}{ Evergreens } \\
\hline \multirow[t]{2}{*}{ All fixed-term } & 64 & 416 & 741 & 1,515 & 410 & 551 & 92 & 55 & 22 & 25 & 23 & 39 & \multicolumn{2}{|r|}{73} \\
\hline & $2 \%$ & $11 \% \quad 1$ & $19 \%$ & $38 \%$ & $10 \%$ & $14 \%$ & $2 \%$ & $1 \%$ & $1 \%$ & $1 \%$ & $1 \%$ & $1 \%$ & \multicolumn{2}{|c|}{$2 \%$} \\
\hline \multirow[t]{2}{*}{ First contract } & 26 & 282 & 506 & 1,132 & 266 & 394 & 55 & 32 & 7 & 10 & 14 & 11 & \multicolumn{2}{|r|}{19} \\
\hline & $1 \%$ & $10 \% \quad 1$ & $19 \%$ & $41 \%$ & $10 \%$ & $14 \%$ & $2 \%$ & $1 \%$ & $0 \%$ & $0 \%$ & $1 \%$ & $0 \%$ & \multicolumn{2}{|c|}{$1 \%$} \\
\hline \multirow[t]{2}{*}{ Renewals } & 38 & 134 & 235 & 383 & 144 & 157 & 37 & 23 & 15 & 15 & 9 & 28 & \multicolumn{2}{|c|}{54} \\
\hline & $3 \%$ & $11 \% \quad 1$ & $19 \%$ & $31 \%$ & $12 \%$ & $13 \%$ & $3 \%$ & $2 \%$ & $1 \%$ & $1 \%$ & $1 \%$ & $2 \%$ & \multicolumn{2}{|c|}{$4 \%$} \\
\hline \multicolumn{15}{|c|}{ Panel B: Descriptive statistics (start of the contract) } \\
\hline & & & \multirow{2}{*}{\multicolumn{3}{|c|}{$\begin{array}{c}\text { Fixed-term } \\
\text { Contracts } \\
\end{array}$}} & \multirow{2}{*}{\multicolumn{2}{|c|}{ At-will }} & \multicolumn{7}{|c|}{ Fixed-term contracts by contract length (years) } \\
\hline & & & & & & & & \multirow{2}{*}{\multicolumn{2}{|c|}{$\frac{1}{1.066}$}} & 2 & \multicolumn{2}{|c|}{3} & \multirow{2}{*}{$\frac{4}{1,480}$} & 5 \\
\hline \multicolumn{3}{|c|}{ Assets (\$ millions) } & \multicolumn{3}{|c|}{1,379} & \multicolumn{2}{|c|}{1,894} & & & 1,198 & $\overline{1,3}$ & 340 & & 1,529 \\
\hline ROA & & & \multicolumn{3}{|c|}{$1.1 \%$} & \multicolumn{2}{|c|}{$4.2 \%$} & \multicolumn{2}{|c|}{$-3.6 \%$} & $-0.3 \%$ & 1.2 & $2 \%$ & $3.5 \%$ & $2.6 \%$ \\
\hline \multicolumn{3}{|c|}{ Annual stock returns } & & $11.9 \%$ & & & $3.7 \%$ & & $.7 \%$ & $11.0 \%$ & 9.7 & $7 \%$ & $17.8 \%$ & $14.2 \%$ \\
\hline Market-to-boo & & & & 2.54 & & & 2.91 & & 2.83 & 2.58 & 2. & 44 & 2.51 & 2.67 \\
\hline Leverage & & & & $24 \%$ & & & $15 \%$ & & $8 \%$ & $25 \%$ & 23 & $3 \%$ & $27 \%$ & $28 \%$ \\
\hline Volatility & & & & 3.16 & & & 3.17 & & 3.28 & 3.39 & 3. & 14 & 3.21 & 3.09 \\
\hline Beta & & & & 0.89 & & & 1.15 & & 0.91 & 0.94 & 0. & 82 & 0.89 & 0.93 \\
\hline Idiosyncratic $\mathrm{r}$ & & & & 2.93 & & & 2.88 & & 3.01 & 3.15 & 2. & 93 & 2.99 & 2.88 \\
\hline $\mathrm{R} \& \mathrm{D} /$ assets & & & & $4 \%$ & & & $7 \%$ & & $9 \%$ & $5 \%$ & 4 & $\%$ & $6 \%$ & $3 \%$ \\
\hline CAPEX/asset & & & & $6 \%$ & & & $7 \%$ & & $7 \%$ & $6 \%$ & 7 & $\%$ & $6 \%$ & $7 \%$ \\
\hline Lag between $\mathrm{F}$ & and & atents & & 0.88 & & & 0.81 & & .76 & 0.86 & 0. & 93 & 1.06 & 0.83 \\
\hline Cycle length - & $\mathrm{x}, \mathrm{pe}$ & & & 4.98 & & & 4.75 & & 4.81 & 4.81 & 4. & 84 & 5.03 & 4.94 \\
\hline Cycle length - & , pea & & & 5.51 & & & 5.27 & & 5.00 & 5.42 & 5. & 34 & 5.63 & 5.68 \\
\hline Cycle length - & eciati & on, peak & & 4.91 & & & 4.29 & & 5.10 & 4.72 & 4. & 74 & 4.81 & 5.20 \\
\hline Cycle length - & $x$, tro & & & 5.91 & & & 6.24 & & 5.88 & 5.89 & 5. & 50 & 6.15 & 5.91 \\
\hline Cycle length - & trou & & & 6.49 & & & 6.81 & & 5.73 & 6.42 & 6. & 34 & 7.13 & 6.52 \\
\hline Cycle length - & eciati & on, trough & & 6.29 & & & 6.22 & & 5.35 & 6.54 & 6. & 14 & 6.26 & 6.43 \\
\hline Firm age & & & & 11.22 & & & 12.49 & & 2.22 & 11.35 & 10 & .17 & 11.57 & 10.44 \\
\hline Analyst foreca & & & & 0.09 & & & 0.09 & & .10 & 0.09 & 0. & 09 & 0.09 & 0.09 \\
\hline Product marke & dity & & & 7.38 & & & 6.80 & & 7.17 & 7.17 & 7. & 95 & 7.31 & 7.20 \\
\hline General ability & & & & -0.06 & & & -0.13 & & 0.13 & -0.04 & -0 . & .01 & -0.14 & 0.05 \\
\hline
\end{tabular}




\begin{tabular}{|c|c|c|c|c|c|c|c|c|c|}
\hline \multicolumn{10}{|c|}{ Panel C: Descriptive statistics (years under fixed-term contracts) } \\
\hline & & $\mathrm{N}$ & Mean & Median & $\begin{array}{l}\text { Standard } \\
\text { deviation }\end{array}$ & Min & Max & $\begin{array}{c}\text { Mean } \\
\text { New } \\
\text { CEO }\end{array}$ & $\begin{array}{c}\text { Mean } \\
\text { Renewed } \\
\text { CEO }\end{array}$ \\
\hline \multirow[t]{14}{*}{ Firm } & Assets (\$ millions) & 7,456 & 1,745 & 568 & 2,561 & 1 & 8,549 & 1,051 & 2,660 \\
\hline & ROA & 7,456 & $4.60 \%$ & $6.54 \%$ & $18.23 \%$ & $-120.29 \%$ & $34.79 \%$ & $-1.71 \%$ & $8.78 \%$ \\
\hline & Annual stock returns & 7,456 & $11.67 \%$ & $7.06 \%$ & $61.52 \%$ & $-80.04 \%$ & $310.92 \%$ & $11.10 \%$ & $13.29 \%$ \\
\hline & Market-to-book & 7,456 & 2.70 & 2.09 & 1.99 & 0.36 & 8.29 & 2.54 & 2.84 \\
\hline & Leverage & 7,456 & $21.60 \%$ & $24.42 \%$ & $34.98 \%$ & $-78.15 \%$ & $134.28 \%$ & $21.50 \%$ & $25.60 \%$ \\
\hline & Volatility & 7,456 & $3.07 \%$ & $2.59 \%$ & $1.74 \%$ & $0.93 \%$ & $9.96 \%$ & $3.22 \%$ & $2.65 \%$ \\
\hline & Beta & 7,456 & 0.90 & 0.90 & 0.59 & -0.57 & 2.61 & 0.84 & 1.07 \\
\hline & Idiosyncratic risk & 7,456 & $2.84 \%$ & $2.35 \%$ & $1.69 \%$ & $0.80 \%$ & $9.37 \%$ & $3.00 \%$ & $2.38 \%$ \\
\hline & R\&D/assets & 7,456 & 0.04 & 0.00 & 0.14 & 0.00 & 1.27 & 0.06 & 0.03 \\
\hline & CAPEX/assets & 7,456 & 0.07 & 0.04 & 0.10 & 0.00 & 0.60 & 0.07 & 0.07 \\
\hline & Finance industry & 7,456 & 0.23 & 0.00 & 0.42 & 0.00 & 1 & 0.26 & 0.13 \\
\hline & Oil and gas industry & 7,456 & 0.03 & 0.00 & 0.18 & 0.00 & 1 & 0.03 & 0.04 \\
\hline & Analyst forecast SD & 5,279 & 0.09 & 0.05 & 0.14 & 0.00 & 3 & 0.09 & 0.09 \\
\hline & Product market fluidity & 5,928 & 7.38 & 6.89 & 3.51 & 0.51 & 24.70 & 6.77 & 7.59 \\
\hline $\mathrm{CEO} /$ & Remaining years & 7,456 & 2.47 & 2.00 & 2.29 & 0.00 & 20.00 & 2.45 & 2.51 \\
\hline \multirow[t]{12}{*}{ Governance } & Age & 7,456 & 54 & 54 & 9 & 25 & 98 & 52 & 55 \\
\hline & Renewal & 7,456 & 0.34 & 0.00 & 0.47 & 0.00 & 1.00 & 0.00 & 1.00 \\
\hline & Percent CEO ownership & 3,348 & 3.53 & 1.50 & 6.21 & 0.00 & 80.80 & 0.58 & 0.55 \\
\hline & Chairman and CEO & 7,456 & $52 \%$ & $100 \%$ & $50 \%$ & $0 \%$ & $100 \%$ & $45 \%$ & $60 \%$ \\
\hline & General ability index & 2,814 & 0.03 & -0.15 & 1.07 & -1.50 & 5.85 & -0.08 & 0.13 \\
\hline & Salary (2000 \$, tds) & 3,348 & 551 & 491 & 301 & 31 & 1,607 & 491 & 658 \\
\hline & Total compensation (2000 \$, tds) & 3,348 & 5,854 & 2,511 & 10,460 & 0.00 & 245,017 & 5,719 & 5,981 \\
\hline & Incentive to total compensation & 3,348 & $41.0 \%$ & $42.8 \%$ & $36.4 \%$ & $0.0 \%$ & $97.5 \%$ & $28.4 \%$ & $62.8 \%$ \\
\hline & Percent unexercisable & 3,348 & 0.10 & 0.00 & 0.22 & 0.00 & 1.00 & 0.04 & 0.25 \\
\hline & Cash compensation & 3,348 & 1,284 & 890 & 1,253 & 0.00 & 7,750 & 1,242 & 1,276 \\
\hline & Total delta & 3,348 & 85.50 & 28.46 & 191.10 & 0.00 & $1,562.19$ & 107.50 & 79.78 \\
\hline & Total vega & 3,348 & 569.71 & 1.09 & $1,675.65$ & 0.00 & $14,300.00$ & 580.71 & 559.47 \\
\hline
\end{tabular}




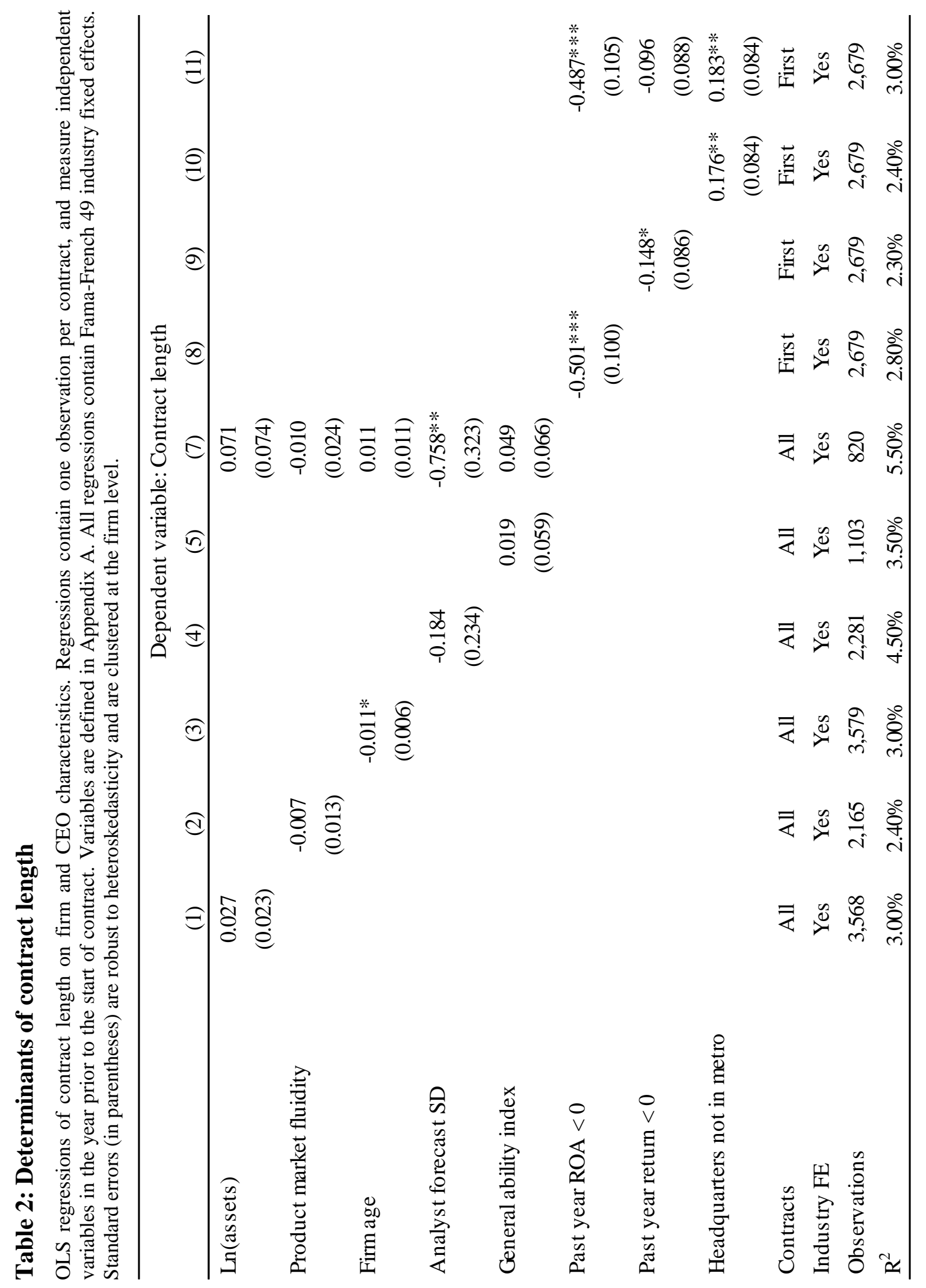




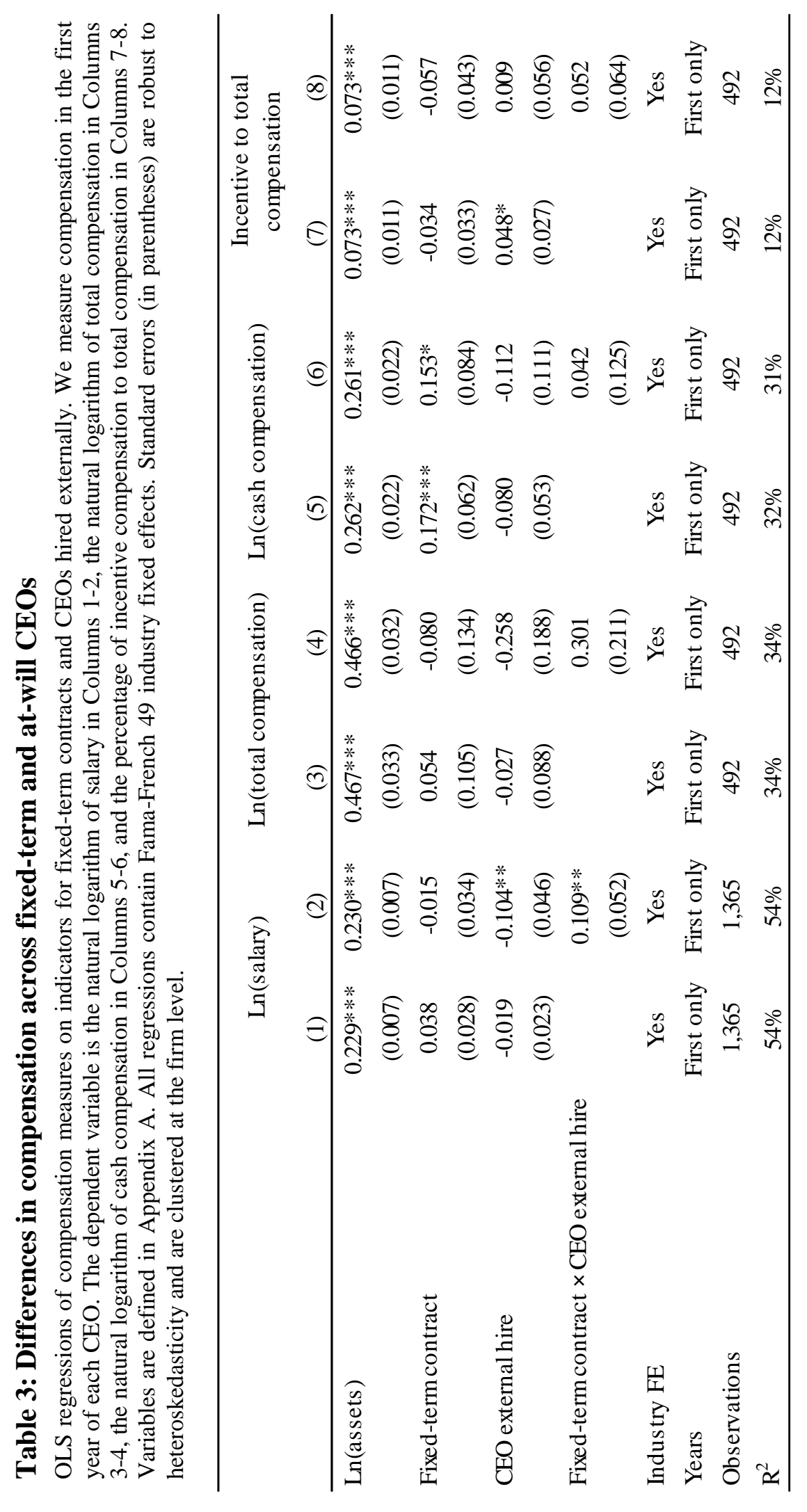




\section{Table 4: Turnover probability (univariate)}

This table presents statistics on turnover and renewals for our sample of contracts starting between 1992 and 2008 and using turnover incidents within the same time period. Panel A reports the percentage of observations with a turnover event out of all years in a given pair of number of remaining years (columns) and contract length (rows). Panel B reports, for contracts of different length (columns), the probability that the CEO is terminated before the last year of the contract (early termination), the probability that the CEO is terminated at contract end, the probability that no turnover happens under the current contract (renewal), as well as statistics for the subsample of renewed contracts. Note that, for one-year contracts, we cannot distinguish between early termination and termination at contract end.

\begin{tabular}{|c|c|c|c|c|c|c|c|}
\hline \multicolumn{8}{|c|}{ Panel A: Turnover probability by contract length and remaining years } \\
\hline \multicolumn{3}{|l|}{ Sample average } & \multicolumn{3}{|c|}{$11.49 \%$} & \multirow{3}{*}{0} & \multirow{3}{*}{0 or 1} \\
\hline Remaining years & 5 & 4 & 3 & 2 & 1 & & \\
\hline \multicolumn{6}{|l|}{ Contract length } & & \\
\hline 1 & & & & & $14 \%$ & $34 \%$ & $21 \%$ \\
\hline 2 & & & & $8 \%$ & $11 \%$ & $25 \%$ & $17 \%$ \\
\hline 3 & & & $6 \%$ & $8 \%$ & $14 \%$ & $30 \%$ & $20 \%$ \\
\hline 2 & & $4 \%$ & $7 \%$ & $13 \%$ & $17 \%$ & $27 \%$ & $21 \%$ \\
\hline 5 & $4 \%$ & $6 \%$ & $8 \%$ & $9 \%$ & $19 \%$ & $32 \%$ & $24 \%$ \\
\hline All contracts & $3 \%$ & $5 \%$ & $7 \%$ & $9 \%$ & $15 \%$ & $29 \%$ & $21 \%$ \\
\hline
\end{tabular}

\begin{tabular}{|c|c|c|c|c|c|}
\hline \multicolumn{6}{|c|}{ Panel B: Renewal probability by contract length } \\
\hline Contract length & 1 & 2 & 3 & 4 & 5 \\
\hline Probability of early termination & & $11 \%$ & $18 \%$ & $21 \%$ & $24 \%$ \\
\hline Probability of termination at contract end & & $17 \%$ & $12 \%$ & $13 \%$ & $10 \%$ \\
\hline Probability of renewal & $68 \%$ & $72 \%$ & $70 \%$ & $66 \%$ & $66 \%$ \\
\hline If renewed: & & & & & \\
\hline Average next contract length & 1.71 & 2.16 & 2.90 & 2.83 & 2.90 \\
\hline Probability of same-length contract & $42 \%$ & $48 \%$ & $60 \%$ & $11 \%$ & $30 \%$ \\
\hline
\end{tabular}

\begin{tabular}{lcccccccc}
\hline \multicolumn{7}{c}{ Panel C: Contract renewal incidence by number of years remaining } \\
\hline Remaining years & 0 & 1 & 2 & 3 & 4 & 5 & $>5$ \\
\hline Percentage of contracts renewed & $35.9 \%$ & $37.1 \%$ & $18.2 \%$ & $5.0 \%$ & $1.8 \%$ & $1.0 \%$ & $1.0 \%$ \\
\hline
\end{tabular}

\begin{tabular}{cccc}
\hline \multicolumn{4}{c}{ Panel D: Renewal statistics by contract length } \\
\hline & $\begin{array}{c}\text { Percentage renewed in last } \\
\text { or penultimate year }\end{array}$ & Remaining contract time at expiration (years) \\
\cline { 3 - 4 } Contract length & & 0.63 & \\
\hline 1 & & 0.63 & \\
2 & $75.43 \%$ & 0.93 & 2.20 \\
3 & $63.64 \%$ & 1.21 & 2.39 \\
4 & $59.83 \%$ & 1.43 & 2.72 \\
5 & $37.50 \%$ & 3.10 & 4.80 \\
\hline 5 & & & Contracts renewed before expiration \\
\hline
\end{tabular}




\section{Table 5: Remaining years under contract and turnover probability}

This table summarizes models of CEO turnover. Columns 1 and 3-7 contain estimates from linear probability models, reporting coefficient estimates with standard errors given underneath. Column 2 reports results from a Cox proportional hazard model; the values shown are hazard ratios for CEO turnover with standard errors given underneath. In the OLS models, the dependent variable is a dummy set to 1 only for the years in which a firm's CEO leaves. Tenure performance is stock return measured over the preceding 5 years or since the start of the CEO's tenure, whichever is shorter, scaled by its standard deviation (see Jenter and Lewellen 2014). Short contracts are contracts with the length of maximum 3 years. Long contracts are those with the length of 4 years or more. All other independent variables are defined in Appendix A. Standard errors (in parentheses) are robust to heteroskedasticity and are clustered at the CEO level. The data span the years 1992-2008. Asterisks indicate that the estimates are significantly different from zero at the *** $1 \%$ level, $* * 5 \%$ level, and $* 10 \%$ level.

\begin{tabular}{|c|c|c|c|c|c|c|c|}
\hline $\begin{array}{l}\text { Sample } \\
\text { Model }\end{array}$ & $\begin{array}{c}\text { All } \\
\text { OLS } \\
(1)\end{array}$ & $\begin{array}{c}\text { All } \\
\text { Cox } \\
(2)\end{array}$ & $\begin{array}{c}\text { Renewed } \\
\text { OLS } \\
\text { (3) }\end{array}$ & $\begin{array}{c}\text { Long } \\
\text { OLS } \\
(4)\end{array}$ & $\begin{array}{c}\text { Short } \\
\text { OLS } \\
(5)\end{array}$ & $\begin{array}{c}\text { All } \\
\text { OLS } \\
(6)\end{array}$ & $\begin{array}{c}\text { All } \\
\text { OLS } \\
(7)\end{array}$ \\
\hline $1-2$ years remaining & $\begin{array}{c}-0.039 * * * \\
(0.009)\end{array}$ & $\begin{array}{c}0.906 \\
(0.100)\end{array}$ & $\begin{array}{c}-0.061 * * * \\
(0.02)\end{array}$ & $\begin{array}{c}-0.005 \\
(0.019)\end{array}$ & $\begin{array}{c}0.013 \\
(0.010)\end{array}$ & $\begin{array}{l}-0.019 \\
(0.013)\end{array}$ & $\begin{array}{c}-0.020 \\
(0.014)\end{array}$ \\
\hline $2-3$ years remaining & $\begin{array}{c}-0.085 * * * \\
(0.009)\end{array}$ & $\begin{array}{c}0.698 * * * \\
(0.083)\end{array}$ & $\begin{array}{c}-0.111 * * * \\
(0.02)\end{array}$ & $\begin{array}{l}-0.028 \\
(0.018)\end{array}$ & $\begin{array}{c}-0.021 * * \\
(0.010)\end{array}$ & $\begin{array}{c}-0.047 * * * \\
(0.013)\end{array}$ & $\begin{array}{c}-0.046 * * * \\
(0.013)\end{array}$ \\
\hline 3-4 years remaining & $\begin{array}{c}-0.108 * * * \\
(0.01)\end{array}$ & $\begin{array}{c}0.525 * * * \\
(0.071)\end{array}$ & $\begin{array}{c}-0.125 * * * \\
(0.021)\end{array}$ & $\begin{array}{c}-0.037 * * \\
(0.018)\end{array}$ & & $\begin{array}{c}-0.070 * * * \\
(0.012)\end{array}$ & $\begin{array}{c}-0.070 * * * \\
(0.013)\end{array}$ \\
\hline 4-5 years remaining & $\begin{array}{c}-0.116^{* * *} * \\
(0.013)\end{array}$ & $\begin{array}{c}0.380 * * * \\
(0.077)\end{array}$ & $\begin{array}{c}-0.144 * * * \\
(0.026)\end{array}$ & $\begin{array}{c}-0.056 * * * \\
(0.018)\end{array}$ & & $\begin{array}{c}-0.081 * * * \\
(0.013)\end{array}$ & $\begin{array}{c}-0.079 * * * \\
(0.014)\end{array}$ \\
\hline$>5$ years remaining & $\begin{array}{c}-0.119^{*} * * \\
(0.013)\end{array}$ & $\begin{array}{c}0.273^{* * *} * \\
(0.060)\end{array}$ & $\begin{array}{c}-0.160 * * * \\
(0.024)\end{array}$ & $\begin{array}{c}-0.067 * * * \\
(0.017)\end{array}$ & & $\begin{array}{c}-0.088^{*} * * \\
(0.012)\end{array}$ & $\begin{array}{c}-0.087 * * * \\
(0.013)\end{array}$ \\
\hline$<1$ year remaining $\times$ return & & & & & & $\begin{array}{l}-0.020 \\
(0.013)\end{array}$ & \\
\hline $1-2$ years remaining $\times$ return & & & & & & $\begin{array}{c}-0.042 * * * \\
(0.011)\end{array}$ & \\
\hline $2-3$ years remaining $\times$ return & & & & & & $\begin{array}{c}-0.038 * * * \\
(0.009)\end{array}$ & \\
\hline 3-4 years remaining $\times$ return & & & & & & $\begin{array}{l}-0.002 \\
(0.012)\end{array}$ & \\
\hline 4-5 years remaining $\times$ return & & & & & & $\begin{array}{c}0.007 \\
(0.013)\end{array}$ & \\
\hline$>4-5$ years remaining $\times$ return & & & & & & $\begin{array}{c}0.002 \\
(0.011)\end{array}$ & \\
\hline$<1$ year remaining $\times$ tenure performance & & & & & & & $\begin{array}{c}-0.011 \\
(0.013)\end{array}$ \\
\hline $1-2$ years remaining $\times$ tenure performance & & & & & & & $\begin{array}{c}-0.024 * * * \\
(0.009)\end{array}$ \\
\hline $2-3$ years remaining $\times$ tenure performance & & & & & & & $\begin{array}{c}-0.026 * * * \\
(0.007)\end{array}$ \\
\hline $3-4$ years remaining $\times$ tenure performance & & & & & & & $\begin{array}{l}-0.002 \\
(0.009)\end{array}$ \\
\hline 4-5 years remaining $\times$ tenure performance & & & & & & & $\begin{array}{l}-0.003 \\
(0.007)\end{array}$ \\
\hline$>5$ years remaining $\times$ tenure performance & & & & & & & $\begin{array}{r}-0.0001 \\
(0.008)\end{array}$ \\
\hline Tenure & $\begin{array}{c}0.001 \\
(0.0008)\end{array}$ & & $\begin{array}{c}-0.005 * * * \\
(0.001)\end{array}$ & $\begin{array}{c}-0.001 * * \\
(0.001)\end{array}$ & $\begin{array}{c}-0.001 * \\
(0.001)\end{array}$ & $\begin{array}{c}-0.002 * * * \\
(0.000)\end{array}$ & $\begin{array}{c}-0.001 * * * \\
(0.000)\end{array}$ \\
\hline Year F.E. & Yes & Yes & Yes & Yes & Yes & Yes & Yes \\
\hline Firm F.E. & Yes & & Yes & Yes & Yes & & \\
\hline \multicolumn{8}{|c|}{ F-test: coefficients of remaining years all equal } \\
\hline F-test & $20.34 * * *$ & & $5.96 * * *$ & $5.736 * * *$ & $9.578 * * *$ & & \\
\hline Estimated turnover probability in renewal years & & & 0.212 & & & & \\
\hline Estimated turnover probability in years after renewals & & & 0.061 & & & & \\
\hline \multicolumn{8}{|c|}{ T-test: renewal $=$ after renewal } \\
\hline T-test & & & $28.37 * * *$ & & & & \\
\hline $\mathrm{N}$ & 7,456 & 7,456 & 3,986 & 3,101 & 4,355 & 7,113 & 7,113 \\
\hline
\end{tabular}




\section{Table 6: Career outcomes}

This table presents information on the relation between remaining years on the CEO's contract and subsequent career outcomes. Panel A shows summary statistics on career outcomes of CEOs in our sample. Remaining years is the average number of years remaining on the CEO's contract at the time of turnover. In the rightmost column, we test whether the number of years remaining for a given career outcome category is significantly different from the case of not finding a better position within 3 years. Panel B shows regressions of a dummy variable that equals 1 if the CEO finds subsequent employment on the number of remaining years of the CEO's contract at the time she leaves the firm. Panel C shows OLS regressions of the employment gap (i.e. the time it takes the CEO to find subsequent employment) on the number of years remaining on the CEO's contract. The data span the years 19922008. Standard errors (in parentheses) are robust to heteroskedasticity. Asterisks indicate that the estimates are significantly different from zero at the *** $1 \%$ level, $* * 5 \%$ level, and $* 10 \%$ level.

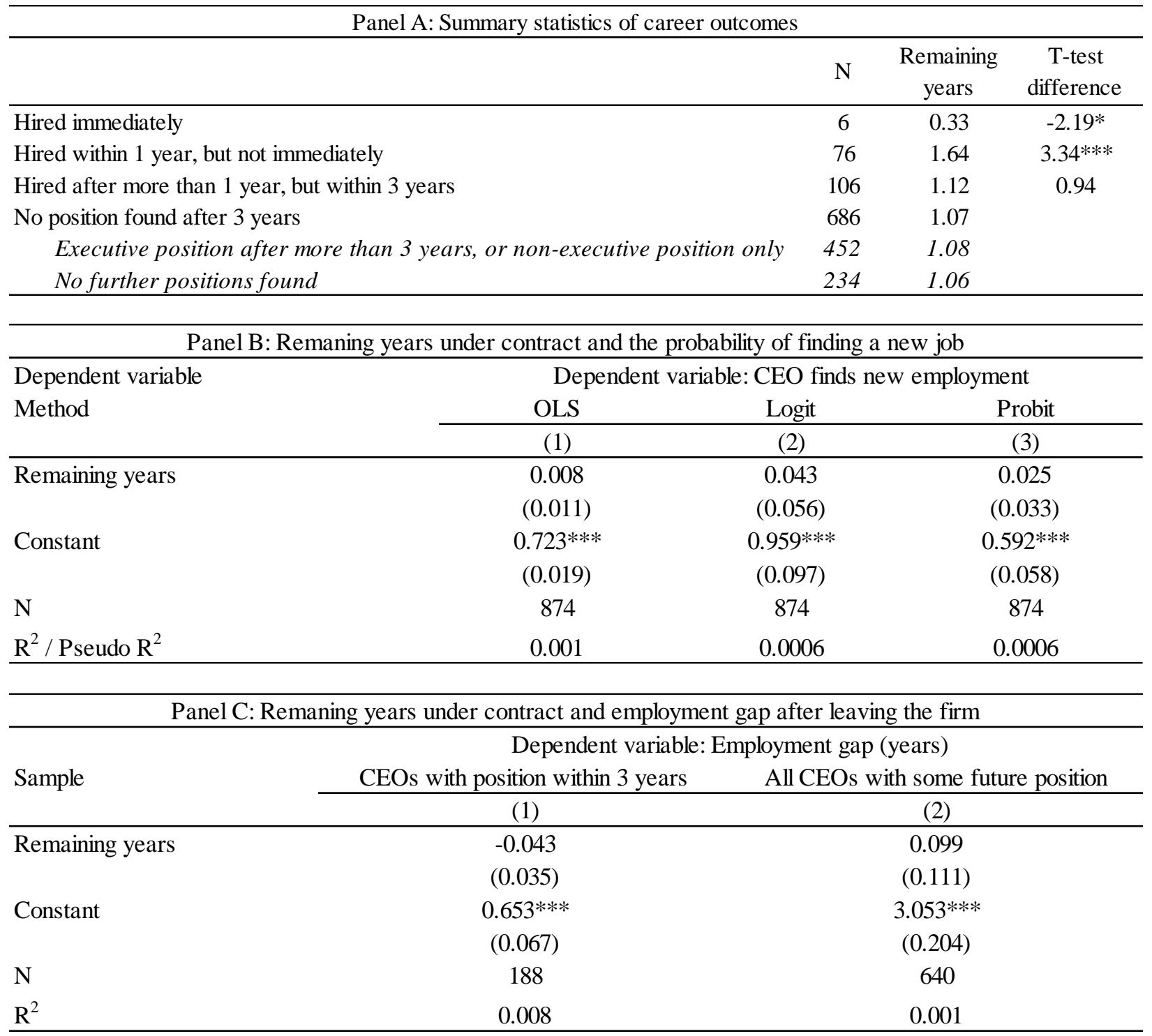




\section{Table 7: Risk}

This table presents regressions of volatility on the number of years remaining on a CEO's contract (Panel A) and summary statistics on changes in volatility at discrete contracting points (Panel B). In Panels A, we present the results of OLS regressions, reporting coefficients with standard errors underneath. The dependent variable is volatility in all regressions of Panel B. Regressions in Columns 1-6 are estimated with CEO fixed effects and the regression in Column 7 is estimated with firm fixed effects. Variables are defined in Appendix A. Standard errors are robust to heteroskedasticity and are clustered at the CEO level. The data span the years 1992-2008. Asterisks indicate that the estimates are significantly different from zero at the *** $1 \%$ level, ** 5\% level, and * $10 \%$ level.

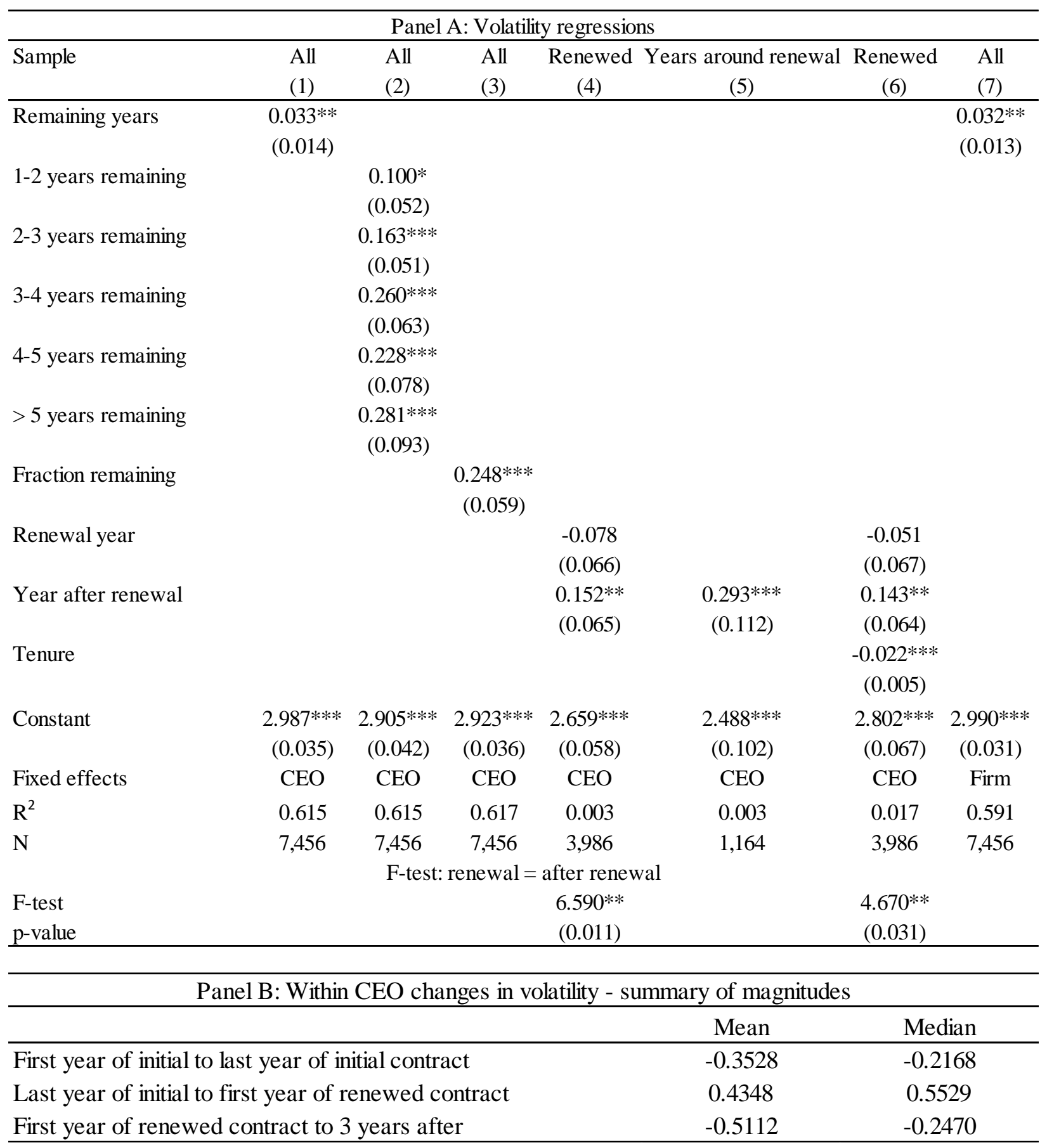




\section{Table 8: Composition of volatility and sources of risk}

This table presents the results of OLS regressions, reporting coefficients with standard errors underneath. The dependent variable is beta in Columns 1-2, idiosyncratic risk in Columns 3-4, capital expenditures divided by total assets in Columns 5-6, and leverage in Columns 7-8. Variables are defined in Appendix A. All regressions are estimated with CEO fixed effects. Standard errors are robust to heteroskedasticity and are clustered at the CEO level. The data span the years 1992-2008. Asterisks indicate that the estimates are significantly different from zero at the $* * * 1 \%$ level, $* * 5 \%$ level, and $* 10 \%$ level.

\begin{tabular}{|c|c|c|c|c|c|c|c|c|}
\hline \multirow[b]{2}{*}{ Sample } & \multicolumn{2}{|c|}{ Beta } & \multicolumn{2}{|c|}{ Idiosyncratic risk } & \multicolumn{2}{|c|}{ Investment } & \multicolumn{2}{|c|}{ Leverage } \\
\hline & $\begin{array}{l}\text { All } \\
(1)\end{array}$ & $\begin{array}{c}\text { Renewed } \\
\text { (2) }\end{array}$ & $\begin{array}{l}\text { All } \\
\text { (3) }\end{array}$ & $\begin{array}{c}\text { Renewed } \\
\text { (4) }\end{array}$ & $\begin{array}{l}\text { All } \\
(5)\end{array}$ & $\begin{array}{c}\text { Renewed } \\
(6)\end{array}$ & $\begin{array}{l}\text { All } \\
(7)\end{array}$ & $\begin{array}{c}\text { Renewed } \\
(8) \\
\end{array}$ \\
\hline Remaining years & $\begin{array}{l}-0.003 \\
(0.005)\end{array}$ & & $\begin{array}{c}0.046^{* * *} \\
(0.014)\end{array}$ & & $\begin{array}{c}0.003 * * * \\
(0.001)\end{array}$ & & $\begin{array}{c}0.006 * * * \\
(0.002)\end{array}$ & \\
\hline Renewal year & & $\begin{array}{l}-0.016 \\
(0.028)\end{array}$ & & $\begin{array}{l}-0.071 \\
(0.060)\end{array}$ & & $\begin{array}{c}-0.012 * * * \\
(0.003)\end{array}$ & & $\begin{array}{l}-0.008 \\
(0.012)\end{array}$ \\
\hline Year after renewal & & $\begin{array}{l}-0.042 \\
(0.028)\end{array}$ & & $\begin{array}{l}0.149 * * \\
(0.059)\end{array}$ & & $\begin{array}{l}0.007 * \\
(0.004)\end{array}$ & & $\begin{array}{l}0.022 * \\
(0.012)\end{array}$ \\
\hline Tenure & & $\begin{array}{c}0.001 \\
(0.002)\end{array}$ & & $\begin{array}{c}-0.023 * * * \\
(0.006)\end{array}$ & & $\begin{array}{c}-0.001 * * * \\
(0.000)\end{array}$ & & $\begin{array}{l}-0.002 * \\
(0.001)\end{array}$ \\
\hline Age & & $\begin{array}{c}-0.0004 \\
(0.002)\end{array}$ & & $\begin{array}{c}-0.011^{* *} \\
(0.005)\end{array}$ & & $\begin{array}{c}-0.001 * * * \\
(0.000)\end{array}$ & & $\begin{array}{l}0.0004 \\
(0.001)\end{array}$ \\
\hline Constant & $\begin{array}{c}0.915^{* * *} \\
(0.011)\end{array}$ & $\begin{array}{c}1.100 * * * \\
(0.102)\end{array}$ & $\begin{array}{c}2.721 * * * \\
(0.033)\end{array}$ & $\begin{array}{c}3.153 * * * \\
(0.272)\end{array}$ & $\begin{array}{c}0.059 * * * \\
(0.002)\end{array}$ & $\begin{array}{c}0.082 * * * \\
(0.004)\end{array}$ & $\begin{array}{c}0.057 * * * \\
(0.002)\end{array}$ & $\begin{array}{c}0.244^{*} * * \\
(0.013)\end{array}$ \\
\hline Fixed effects & CEO & CEO & CEO & CEO & CEO & CEO & CEO & CEO \\
\hline $\mathrm{R}^{2}$ & 0.387 & 0.000 & 0.629 & 0.030 & 0.535 & 0.016 & 0.534 & 0.004 \\
\hline $\mathrm{N}$ & 7,456 & 3,986 & 7,456 & 3,986 & 7,456 & 3,986 & 7,456 & 3,986 \\
\hline & & & renewal $=$ & $=$ after rer & & & & \\
\hline $\begin{array}{l}\text { F-test } \\
\text { p-value }\end{array}$ & & $\begin{array}{c}0.628 \\
(0.428)\end{array}$ & & $\begin{array}{c}7.258 * * * \\
(0.007)\end{array}$ & & $\begin{array}{c}12.314^{* * * *} \\
(0.000)\end{array}$ & & $\begin{array}{c}3.977 * * \\
(0.046)\end{array}$ \\
\hline
\end{tabular}




\section{Table 9: Robustness: compensation, first year in office, CEO age, and firm age}

This table presents the results of OLS regressions, reporting coefficients with standard errors underneath. The dependent variable is volatility. Independent variables are defined in Appendix A. All regressions contain CEO fixed effects. Standard errors are robust to heteroskedasticity and are clustered at the CEO level. The data span the years 1992-2008. Asterisks indicate that the estimates are significantly different from zero at the *** $1 \%$ level, ** $5 \%$ level, and * $10 \%$ level.

\begin{tabular}{|c|c|c|c|c|c|c|}
\hline \multicolumn{7}{|c|}{ Dependent variable: volatility } \\
\hline & Compensation & Coles et al. & Coles et al. & No first year & CEO age & Firm age \\
\hline & $(1)$ & $(2)$ & (3) & $(4)$ & $(5)$ & $(6)$ \\
\hline \multirow[t]{2}{*}{ Remaining years } & $0.029 * *$ & $0.030 * *$ & $0.029 * *$ & $0.037 * * *$ & & \\
\hline & $(0.014)$ & $(0.014)$ & $(0.014)$ & $(0.012)$ & & \\
\hline \multirow{2}{*}{ Sensitivity of unvested equity grants } & 1.851 & 1.631 & 1.639 & & & \\
\hline & $(1.175)$ & $(1.103)$ & (1.107) & & & \\
\hline \multirow[t]{2}{*}{ Sensitivity of vested equity grants } & -0.159 & -0.212 & -0.209 & & & \\
\hline & $(0.241)$ & $(0.230)$ & $(0.231)$ & & & \\
\hline \multirow[t]{2}{*}{ Vega of unvested equity grants } & $0.101 * * *$ & $0.112 * * *$ & $0.112 * * *$ & & & \\
\hline & $(0.027)$ & $(0.028)$ & $(0.028)$ & & & \\
\hline \multirow[t]{2}{*}{ Vega of vested equity grants } & $-0.052 * *$ & $-0.056^{* *}$ & $-0.055 * *$ & & & \\
\hline & $(0.021)$ & $(0.022)$ & $(0.021)$ & & & \\
\hline \multirow{2}{*}{ Ln(total compensation) } & -0.026 & -0.020 & -0.017 & & & \\
\hline & $(0.023)$ & $(0.020)$ & $(0.022)$ & & & \\
\hline \multirow{2}{*}{ Cash compensation } & -0.009 & & -0.013 & & & \\
\hline & $(0.028)$ & & $(0.028)$ & & & \\
\hline \multirow[t]{2}{*}{ Total assets } & & $1.942 * * *$ & $1.979 * * *$ & & & \\
\hline & & $(0.731)$ & $(0.728)$ & & & \\
\hline \multirow[t]{2}{*}{ Market-to-book } & & $-0.056^{* *}$ & $-0.056^{* *}$ & & & \\
\hline & & $(0.022)$ & $(0.022)$ & & & \\
\hline \multirow[t]{2}{*}{ CAPEX/assets } & & -0.277 & -0.282 & & & \\
\hline & & $(0.544)$ & $(0.543)$ & & & \\
\hline \multirow[t]{2}{*}{$\mathrm{R} \& \mathrm{D} / \mathrm{assets}$} & & $1.110 * *$ & $1.112 * *$ & & & \\
\hline & & $(0.463)$ & $(0.463)$ & & & \\
\hline \multirow[t]{2}{*}{ Leverage } & & $0.483 * *$ & $0.483 * *$ & & & \\
\hline & & $(0.221)$ & $(0.221)$ & & & \\
\hline \multirow[t]{2}{*}{ Compensation data missing (dummy) } & 0.081 & 0.093 & 0.100 & & & \\
\hline & $(0.194)$ & $(0.187)$ & $(0.191)$ & & & \\
\hline \multirow[t]{2}{*}{ Renewal year } & & & & & -0.058 & -0.048 \\
\hline & & & & & $(0.067)$ & $(0.067)$ \\
\hline \multirow[t]{2}{*}{ Year after renewal } & & & & & $0.146^{* *}$ & $0.127 * *$ \\
\hline & & & & & $(0.066)$ & $(0.062)$ \\
\hline \multirow[t]{2}{*}{ Log CEO age } & & & & & $-0.944 * * *$ & \\
\hline & & & & & $(0.290)$ & \\
\hline \multirow[t]{2}{*}{ Firm age $4-9$ years } & & & & & & -0.136 \\
\hline & & & & & & $(0.128)$ \\
\hline \multirow[t]{2}{*}{ Firm age $>9$ years } & & & & & & $-0.712 * * *$ \\
\hline & & & & & & $(0.158)$ \\
\hline \multirow[t]{2}{*}{ Constant } & $3.033 * * *$ & $2.996^{* * *}$ & $2.989 * * *$ & $2.985 * * *$ & $6.437 * * *$ & $3.140 * * *$ \\
\hline & $(0.200)$ & $(0.198)$ & $(0.201)$ & $(0.031)$ & $(1.165)$ & $(0.135)$ \\
\hline CEO F.E. & Yes & Yes & Yes & Yes & Yes & Yes \\
\hline $\mathrm{R}^{2}$ & 0.620 & 0.625 & 0.625 & 0.609 & 0.010 & 0.036 \\
\hline $\mathrm{N}$ & 7,456 & 7,456 & 7,456 & 6,058 & 3,986 & 3,986 \\
\hline \multicolumn{7}{|c|}{ F-test: renewal $=$ after renewal } \\
\hline F-test & & & & & $5.013 * *$ & $4.045^{* *}$ \\
\hline p-value & & & & & $(0.001)$ & $(0.045)$ \\
\hline
\end{tabular}


Table 10: Sample composition effects: robustness to CEO survival and to contract length

This table presents the results of OLS regressions, reporting coefficients with standard errors underneath. The dependent variable is volatility. Columns 1-2 repeat the result of selected models from Table 7 for CEOs whose contracts are not renewed. Each of Columns 3-6 presents regression results for the subsample indicated in the column heading. Short contracts are defined as those with a length of maximum three years; long contracts are those with a length exceeding three years. Variables are defined in Appendix A. Standard errors are robust to heteroskedasticity and are clustered at the CEO level. Asterisks indicate that the estimates are significantly different from zero at the *** $1 \%$ level, $* * 5 \%$ level, and $* 10 \%$ level.

\begin{tabular}{|c|c|c|c|c|c|c|}
\hline \multirow[t]{2}{*}{ Subsample } & \multicolumn{2}{|c|}{ Non-renewed CEOs } & \multirow{2}{*}{$\begin{array}{c}\text { Short contracts } \\
\text { (3) }\end{array}$} & \multirow{2}{*}{$\begin{array}{c}\text { Long contracts } \\
\text { (4) }\end{array}$} & \multirow{2}{*}{$\begin{array}{c}\text { Short contracts } \\
\text { (5) }\end{array}$} & \multirow{2}{*}{$\begin{array}{c}\text { Long contracts } \\
(6)\end{array}$} \\
\hline & $(1)$ & (2) & & & & \\
\hline Remaining years & $\begin{array}{l}0.032 * * \\
(0.016)\end{array}$ & & $\begin{array}{l}0.060 * * \\
(0.027)\end{array}$ & $\begin{array}{l}0.029^{*} \\
(0.017)\end{array}$ & & \\
\hline Fraction remaining & & $\begin{array}{c}0.272 * * * \\
(0.073)\end{array}$ & & & $\begin{array}{c}0.225 * * * \\
(0.071)\end{array}$ & $\begin{array}{l}0.300^{* *} \\
(0.119)\end{array}$ \\
\hline Constant & $\begin{array}{c}3.007^{* * * *} \\
(0.036)\end{array}$ & $\begin{array}{c}2.927 * * * \\
(0.043)\end{array}$ & $\begin{array}{c}2.899 * * * \\
(0.062)\end{array}$ & $\begin{array}{c}2.999 * * * * \\
(0.039)\end{array}$ & $\begin{array}{c}2.806 * * * * \\
(0.07)\end{array}$ & $\begin{array}{c}2.963 * * * \\
(0.039)\end{array}$ \\
\hline CEO F.E. & Yes & Yes & Yes & Yes & Yes & Yes \\
\hline $\mathrm{R}^{2}$ & $63 \%$ & $63 \%$ & $66 \%$ & $69 \%$ & $67 \%$ & $69 \%$ \\
\hline $\mathrm{N}$ & 3,470 & 3,470 & 4,279 & 3,177 & 4,279 & 3,177 \\
\hline \multicolumn{7}{|c|}{ F-test: equality of slope coefficients for short and long contracts } \\
\hline $\begin{array}{l}\text { F-test } \\
\text { p-value }\end{array}$ & & & $\begin{array}{l}1 . \\
(0 .\end{array}$ & $\begin{array}{l}40 \\
307)\end{array}$ & $\begin{array}{r}0.5 \\
(0.4\end{array}$ & $\begin{array}{l}580 \\
448)\end{array}$ \\
\hline
\end{tabular}

\section{Table 11: Heterogeneity and mechanism}

This table presents the results of OLS regressions, reporting coefficients with standard errors underneath. The dependent variable is volatility. We interact contract-related variables with dummies for CEOs over/below the retirement age of 65 (Column 1), for CEOs over/below 62 years of age (Column 2), founder CEOs (Column 3), CEOs with a tenure longer than/at most 5 years (Column 4), and for firms with high/low product market fluidity based on the measure of Hoberg, Phillips, and Prabhala (2014) (Column 5). All regressions contain CEO fixed effects. Other variables are defined in Appendix A. Standard errors are robust to heteroskedasticity and are clustered at the CEO level. The data span the years 1992-2008. Asterisks indicate that the estimates are significantly different from zero at the $* * * 1 \%$ level, $* * 5 \%$ level, and $* 10 \%$ level.

\begin{tabular}{|c|c|c|c|c|c|}
\hline \multicolumn{6}{|c|}{ Dependent variable: Volatility } \\
\hline Group 1 & Under 65 & Under 62 & Not founder & Tenure $\geq 5$ & High fluidity \\
\hline Group 2 & $\begin{array}{c}\text { Over } 65 \\
\text { (1) }\end{array}$ & $\begin{array}{l}\text { Over } 62 \\
\text { (2) }\end{array}$ & $\begin{array}{c}\text { Founder CEO } \\
\text { (3) }\end{array}$ & $\begin{array}{c}\text { Tenure }<5 \\
\text { (4) }\end{array}$ & $\begin{array}{l}\text { Low fluidity } \\
\text { (5) }\end{array}$ \\
\hline Group 1 & & & & & $\begin{array}{c}0.044 \\
(0.128)\end{array}$ \\
\hline Group $1 \times$ remaining years & $\begin{array}{c}0.042 * * * \\
(0.015)\end{array}$ & $\begin{array}{c}0.046^{* * * *} \\
(0.018)\end{array}$ & $\begin{array}{l}0.037 * * \\
(0.014)\end{array}$ & $\begin{array}{c}0.044 * * * \\
(0.017)\end{array}$ & $\begin{array}{l}0.040^{*} \\
(0.023)\end{array}$ \\
\hline Group $2 \times$ remaining years & $\begin{array}{c}0.01 \\
(0.024)\end{array}$ & $\begin{array}{c}0.008 \\
(0.016)\end{array}$ & $\begin{array}{c}0.021 \\
(0.038)\end{array}$ & $\begin{array}{c}0.006 \\
(0.033)\end{array}$ & $\begin{array}{c}0.071^{* * * *} \\
(0.025)\end{array}$ \\
\hline Constant & $\begin{array}{c}2.972 * * * \\
(0.039)\end{array}$ & $\begin{array}{c}2.988 * * * \\
(0.045)\end{array}$ & $\begin{array}{c}2.973 * * * \\
(0.034)\end{array}$ & $\begin{array}{c}2.980 * * * \\
(0.036)\end{array}$ & $\begin{array}{c}3.005^{* * * *} \\
(0.074)\end{array}$ \\
\hline CEO F.E. & Yes & Yes & Yes & Yes & Yes \\
\hline $\mathrm{R}^{2}$ & $61 \%$ & $62 \%$ & $66 \%$ & $62 \%$ & $60 \%$ \\
\hline $\mathrm{N}$ & 7,456 & 7,456 & 7,456 & 7,456 & 5,427 \\
\hline \multicolumn{6}{|c|}{ F-test: equality of slope coefficients } \\
\hline $\begin{array}{l}\text { F-test } \\
\text { p-value }\end{array}$ & $\begin{array}{c}1.692 \\
(0.193)\end{array}$ & $\begin{array}{l}2.770^{*} \\
(0.096)\end{array}$ & $\begin{array}{c}0.600 \\
(0.439)\end{array}$ & $\begin{array}{c}1.065 \\
(0.302)\end{array}$ & $\begin{array}{c}0.999 \\
(0.318)\end{array}$ \\
\hline
\end{tabular}




\section{Table 12: Alternative cycles}

Panel A presents descriptive statistics of alternative cycle and contract horizon measures. Panel B reports the coefficients of years remaining (and standard errors underneath) for 18 regressions where the dependent variable is volatility and the independent variables are the number of years remaining in technological cycle (or its lead, or its lag, respectively, as indicated by the row caption) and CEO fixed effects, and where the sample is CEOs employed under at-will contracts. We infer the length of technological cycles from peaks (troughs) in capital expenditures, sales, and depreciation (indicated in the column caption). Panel $\mathrm{C}$ shows regressions of volatility on dummy variables indicating the year of a 15\% or larger raise in compensation and the year after. Panel D shows estimates from regressions of volatility on the number of years remaining in matched contract cycles for CEOs employed at will (see Appendix D for details). In Panel D, we infer cycle peaks from peaks in volatility in Columns 1-2, and from increases in compensation in Columns 3-4. We match firms based on size and Tobin's Q in all columns. In Columns 2 and 4 in addition, we require an exact match on industry. For firms with multiple peaks, we estimate cycle length as the average over time. All regressions in Panels B, C and D include CEO fixed effects. Standard errors in Panels B, C, and D are robust to heteroskedasticity and are clustered at the CEO level. Asterisks indicate that the estimates are significantly different from zero at the *** $1 \%$ level, ** 5\% level, and $* 10 \%$ level.

\begin{tabular}{lccc}
\hline \multicolumn{4}{c}{ Panel A: Descriptive statistics of alternative cycle and predicted contracts } \\
\hline & $\begin{array}{c}\text { Length } \\
\text { (in years) }\end{array}$ & $\begin{array}{c}\text { Within-firm } \\
\text { st.dev. }\end{array}$ & $\begin{array}{c}\text { Difference to actual contract } \\
\text { (in remaining years) }\end{array}$ \\
\cline { 2 - 4 } Cycle length - peaks & & & \\
CAPEX & 4.98 & 0.51 & 1.01 \\
Sales & 5.50 & 0.28 & 1.27 \\
Depreciation & 4.84 & 0.23 & 1.20 \\
Cycle length - troughs & & & \\
CAPEX & 5.91 & 0.78 & 1.11 \\
Sales & 6.49 & 0.53 & 1.49 \\
Depreciation & 6.29 & 0.49 & 1.33 \\
\hline
\end{tabular}

Panel B: Remaining years in technological cycles and volatility for CEOs under at-will contracts

\begin{tabular}{lcccccc}
\hline \multirow{2}{*}{ Cycle } & \multicolumn{3}{c}{ Peak-to-Peak } & \multicolumn{3}{c}{ Trough-to-Trough } \\
\cline { 2 - 7 } & CAPEX & Sales & Depreciation & CAPEX & Sales & Depreciation \\
& $(1)$ & $(2)$ & $(3)$ & $(4)$ & $(5)$ & $(6)$ \\
\hline Remaining years & $-0.043^{* *}$ & $-0.092^{* * *}$ & $-0.100^{* * *}$ & $-0.084^{* * *}$ & -0.086 & $-0.419^{*}$ \\
& $(0.021)$ & $(0.031)$ & $(0.032)$ & $(0.028)$ & $(0.102)$ & $(0.241)$ \\
CEO F.E. & Yes & Yes & Yes & Yes & Yes & Yes \\
\hline
\end{tabular}




\begin{tabular}{|c|c|c|c|c|c|c|}
\hline \multicolumn{7}{|c|}{ Panel C: Risk-taking in firms with no fixed-term contracts } \\
\hline Dependent variable & $\begin{array}{c}\text { Volatility } \\
\text { (1) }\end{array}$ & $\begin{array}{l}\text { Volatility } \\
\text { (2) }\end{array}$ & $\begin{array}{l}\text { Beta } \\
\text { (3) }\end{array}$ & $\begin{array}{l}\text { Beta } \\
(4)\end{array}$ & $\begin{array}{c}\text { Idiosyncratic risk } \\
\text { (5) }\end{array}$ & $\begin{array}{c}\text { Idiosyncratic risk } \\
(6)\end{array}$ \\
\hline Year before raise & $\begin{array}{c}0.215^{* * * *} \\
(0.062)\end{array}$ & $\begin{array}{c}0.183 * * * * \\
(0.070)\end{array}$ & $\begin{array}{c}0.000 \\
(0.000)\end{array}$ & $\begin{array}{c}0.000 \\
(0.000)\end{array}$ & $\begin{array}{c}0.314 * * * \\
(0.058)\end{array}$ & $\begin{array}{c}0.274 * * * \\
(0.064)\end{array}$ \\
\hline Year after raise & $\begin{array}{c}0.1 \\
(0.111)\end{array}$ & $\begin{array}{l}-0.004 \\
(0.130)\end{array}$ & $\begin{array}{c}0.000 \\
(0.001)\end{array}$ & $\begin{array}{c}0.000 \\
(0.001)\end{array}$ & $\begin{array}{l}0.184 * \\
(0.102)\end{array}$ & $\begin{array}{c}0.063 \\
(0.121)\end{array}$ \\
\hline Tenure & & $\begin{array}{c}-0.024 * * * \\
(0.007)\end{array}$ & & $\begin{array}{c}0.000 \\
(0.000)\end{array}$ & & $\begin{array}{c}-0.024 * * * \\
(0.007)\end{array}$ \\
\hline CEO F.E. & Yes & Yes & Yes & Yes & Yes & Yes \\
\hline $\begin{array}{l}\text { F-test }(\text { before=after) } \\
\text { p-value }\end{array}$ & $\begin{array}{c}0.75 \\
(0.388)\end{array}$ & $\begin{array}{c}1.47 \\
(0.226)\end{array}$ & $\begin{array}{c}0.80 \\
(0.371)\end{array}$ & $\begin{array}{c}0.43 \\
(0.511)\end{array}$ & $\begin{array}{c}1.13 \\
(0.289)\end{array}$ & $\begin{array}{c}2.12 \\
(0.146)\end{array}$ \\
\hline $\mathrm{R}^{2}$ & 0.632 & 0.633 & 0.279 & 0.276 & 0.627 & 0.633 \\
\hline $\mathrm{N}$ & 1,917 & 1,863 & 1,917 & 1,863 & 1,917 & 1,863 \\
\hline \multicolumn{7}{|c|}{ Panel D: Remaining years in cycles and volatility for CEOs without fixed-term contracts } \\
\hline \multirow{2}{*}{\multicolumn{2}{|c|}{ Cycle length matched on }} & \multicolumn{3}{|c|}{ Volatility peaks } & \multicolumn{2}{|c|}{ Compensation increases } \\
\hline & & & (2) & (3) & (4) \\
\hline \multicolumn{2}{|c|}{ Remaining years - matched cycle } & \multicolumn{2}{|c|}{0.009} & $\begin{array}{l}-0.007 \\
(0.034)\end{array}$ & $\begin{array}{l}-0.027 \\
(0.027)\end{array}$ & $\begin{array}{l}-0.005 \\
(0.047)\end{array}$ \\
\hline \multicolumn{2}{|l|}{ Constant } & \multicolumn{2}{|c|}{$\begin{array}{c}2.856 * * * \\
(0.072)\end{array}$} & $\begin{array}{c}2.890 * * * \\
(0.072)\end{array}$ & $\begin{array}{c}3.071 * * * \\
(0.064)\end{array}$ & $\begin{array}{c}3.022 * * * \\
(0.109)\end{array}$ \\
\hline \multicolumn{2}{|l|}{ CEO F.E. } & \multicolumn{2}{|c|}{ Yes } & Yes & Yes & Yes \\
\hline \multicolumn{2}{|l|}{ R-squared } & \multicolumn{2}{|c|}{$59.6 \%$} & $59.1 \%$ & $61.5 \%$ & $61.3 \%$ \\
\hline \multicolumn{2}{|l|}{$\mathrm{N}$} & \multicolumn{2}{|c|}{1,432} & 1,411 & 1,331 & 1,327 \\
\hline \multicolumn{2}{|c|}{ Exact industry match? } & \multicolumn{2}{|c|}{ No } & Yes & No & Yes \\
\hline
\end{tabular}




\section{Appendix A: Variable Definitions}

This Appendix defines the variables that are used in the main analysis of the paper and are not described in detail the text.

\section{Variable Definitions}

\begin{tabular}{|c|c|}
\hline Age & Executive's age in years \\
\hline$A I M R$ & Industry adjusted AIMR scores (see Brown and Hillegeist, 2007) \\
\hline Analyst forecast $S D$ & Standard deviation of analyst forecasts of the current year's EPS \\
\hline Anti-takeover & State with "business combination laws" according to Bertrand and Mullainathan \\
\hline Annual stock returns & Stock returns over the past year \\
\hline Assets & Book assets (in $\$$ millions) \\
\hline Beta & $\begin{array}{l}\text { Coefficient on the market excess returns in a regression in which the dependent } \\
\text { variable is the daily stock return, run for each firm-year }\end{array}$ \\
\hline Book-to-market (B/M) & $\begin{array}{l}\text { Ratio of the book value of assets to the market value of assets: the market value is } \\
\text { calculated as the sum of the book value of assets and the market value of common } \\
\text { stock less the book value of common stock, cash, and deferred taxes. Market } \\
\text { values are measured at the end of the fiscal year }\end{array}$ \\
\hline Busy directors (\%) & $\begin{array}{l}\text { Number of directors holding three or more directorships, defined as "busy" by Fich } \\
\text { and Shivdasani (2006) divided by the total number of directors on the board. }\end{array}$ \\
\hline CAPEX/assets & Capital expenditures divided by lagged assets \\
\hline Cash compensation & Salary plus bonus (in $\$$ thousands) \\
\hline CEO external hire & 1 if the CEO was hired from outside the firm \\
\hline Chairman and CEO & 1 if the CEO also holds the Chairman position of the Board \\
\hline Change in $R O A$ & $\begin{array}{l}\text { ROA in the second half of the contract (defined as years in which the CEO has } \\
\text { less than half of her contract remaining) minus ROA in the first half of the } \\
\text { contract }\end{array}$ \\
\hline Contract length & Expiration year minus start year of the contract \\
\hline Credit rating dummy & 1 if the firm has a credit rating \\
\hline Cycle length & $\begin{array}{l}\text { The average length of a cycle in capital expenditures, sales, or depreciation. For } \\
\text { each variable, we define a peak (trough) year as one in which the variable grows } \\
\text { (falls) by at least } 5 \% \text {. The length of the cycle for a given firm is the average } \\
\text { distance between two peaks (troughs). }\end{array}$ \\
\hline Dividend & 1 if the fim pays dividends in the current year \\
\hline Exception rule & 1 if the contract is governed by the law of a state with a good faith \& fair dealing \\
\hline Firm age & $\begin{array}{l}\text { Number of years since incorporation, or if not available, since the appearance of } \\
\text { the firm in Compustat }\end{array}$ \\
\hline Former $C E O$ & 1 if the CEO was in office before the current contract \\
\hline Founder & 1 if the CEO is the founder of the firm \\
\hline Fraction remaining & Remaining years dividend by contract length \\
\hline General ability index & The general ability index (GAI) of Custódio, Ferreira, and Matos (2013) \\
\hline Garmaise & Index of Garmaise (2006) \\
\hline Governance index & The index developed by Gompers, Ishii and Metrick (2003) \\
\hline Headquarters not in metro & $\begin{array}{l}1 \text { if the firm's headquarters are located outside a metropolitan statistical area as } \\
\text { defined by the U.S. Census Bureau }\end{array}$ \\
\hline
\end{tabular}




\begin{tabular}{|c|c|}
\hline Idiosyncratic risk & $\begin{array}{l}\text { Standard deviation of residuals in a Fama-French three-factor model, estimated for } \\
\text { each firm-year }\end{array}$ \\
\hline Incentive to total compensation & Value of bonus, stock, and option grants to total CEO pay \\
\hline Independent directors $(\%)$ & Number of independent directors divided by the number of directors on the board. \\
\hline Industry homogeneity & Median (across all firms of one of the 49 Fama-French industries) of the \\
\hline In metro & 1 if the firm is headquartered in a metrpolitan area (Source: Census Bureau) \\
\hline Leverage & Net debt divided by total assets \\
\hline Low analyst forecast error & 1 if analyst forecast STD is below median \\
\hline News releases & Number of news releases (Capital IQ) \\
\hline Percent insiders on board & Percentage of insiders among board members \\
\hline Product market fluidity & $\begin{array}{l}\text { The text-based measure of product market fluidity developed by Hoberg, Philips, } \\
\text { and Prabhala (2014) }\end{array}$ \\
\hline$R \& D /$ assets & Research and development expenditures divided by lagged assets \\
\hline Remaining years & Expiration year minus current year \\
\hline Renewal year & 1 if the contract is due to expire in the following year \\
\hline Return on assets (ROA) & Earnings before interest and taxes divided by assets \\
\hline $\begin{array}{l}\text { Sensitivity of vested equity } \\
\text { grants }\end{array}$ & $\begin{array}{l}\text { Sensitivity of vested equity grants with respect to a } 1 \% \text { change in the stock price } \\
\text { calculated using the method of Core and Guay (2002), in } \$ \text { thousands }\end{array}$ \\
\hline $\begin{array}{l}\text { Sensitivity of unvested equity } \\
\text { grants }\end{array}$ & $\begin{array}{l}\text { Sensitivity of unvested equity grants with respect to a } 1 \% \text { change in the stock price } \\
\text { calculated using the method of Core and Guay (2002), in } \$ \text { thousands }\end{array}$ \\
\hline Salary & CEO's base salary in thousands of US\$, adjusted to $2000 \$$ \\
\hline Tenure & Number of years the CEO has been in office \\
\hline Tenure performance & $\begin{array}{l}\text { The stock return measured over the preceding } 5 \text { years, or since the start of the } \\
\text { CEO's tenure, whichever is shorter, scaled by its standard deviation }\end{array}$ \\
\hline Total compensation & CEO's total annual compensation (TDC1) in thousands of US\$, adjusted to $2000 \$$ \\
\hline Total delta & Sensitivity of vested plus unvested equity grants \\
\hline Total vega & Vega of vested plus unvested equity grants \\
\hline Turnover & 1 if the executive leaves the CEO position \\
\hline Turnover pr & Fitted value of regressions reported in Table 3 \\
\hline Vega of vested equity grants & $\begin{array}{l}\text { Sensitivity of vested equity grants with respect to a } 0.01 \text { change in return volatility } \\
\text { calculated using the method of Core and Guay (2002), in } \$ \text { thousands }\end{array}$ \\
\hline Vega of unvested equity grants & $\begin{array}{l}\text { Sensitivity of unvested equity grants with respect to a } 0.01 \text { change in return } \\
\text { volatility calculated using the method of Core and Guay (2002), in \$ thousands }\end{array}$ \\
\hline Volatility & Standard deviation of daily stock returns \\
\hline
\end{tabular}




\section{Internet Appendix to "CEO turnover and volatility under long-term employment contracts"}

This Appendix provides additional analyses and results for our paper "CEO turnover and volatility under long-term employment contracts". The discussion can be found in the main text of the paper; the tables are referred to as A-\#, where \# is the table number in Appendix. 


\section{Appendix B: CEO turnover - robustness}

This section contains and describes robustness tests for our turnover regressions.

Logit. Most literature on CEO turnover employs models using logit regressions (Denis, Denis, and Sarin 1997; Mikkelson and Partch 1997; Perry 1999; Huson, Parrino, and Starks 2001) or probit regressions (Jenter and Lewellen 2014). ${ }^{14}$ In Table A-1, Column 1 shows that the estimates obtained from a logit model of CEO turnover are similar to those of the linear probability model and the Cox hazard model in Table 5 of the paper: specifically, CEOs with more years remaining to contract expiration are less likely to leave the firm.

Fixed effects. Column 2 of Table A-1 shows that the results of our turnover models remain similar if we use CEO fixed effects instead of firm fixed effects. Our results hold similarly if we use industry fixed effects. These models are shown in Table A-5, Columns 1 and 3 (Internet Appendix C).

Tenure and age. In Column 3 of Table A-1, we also control for CEO tenure and age. Since tenure and age cannot be identified separately in a linear model that includes executive- and year fixed effects, we follow Berndt and Griliches (1993) and drop a subset of dummy variables. As shown by Pan, Wang and Weisbach (2013) who use dummy variables for tenure below three and over six, tenure effects are not linear. Dummy variables also allow us to capture potentially linear effects and non-linear effects. Our results remain similar.

Voluntary turnover. Executives may leave voluntarily, either because they receive unsolicited external offers, or because they had been scouting for offers when their turnover probabilities were high. Unsolicited external offers may reflect the performance in comparable firms, rather than contractual protection. We show that voluntary turnover events are not driving the result that remaining time under contract predicts CEO turnover. Our data include 187 voluntary CEO turnovers, identified following the Parrino (1997) algorithm by Jenter and Kanaan (2015), Peters and Wagner (2013), Eisfeldt and Kuhnen (2013), and in our own search. Table A-2 contains a break-down of the number of CEO turnover observations. As in Jenter and Kanaan (2015), we now treat voluntary turnovers as right-censored

\footnotetext{
${ }^{14}$ For a review of the literature on CEO turnover, see Brickley (2003).
} 
observations and re-estimate the OLS models in Table 5 Column 1 and Table A-1 Column 3. Columns 45 in Table A-1 show the results. We find that CEOs with 1-2 years remaining are not less likely to be dismissed than CEOs with less than one year; however, CEOs with more than 2 years are significantly more likely to be dismissed, in line with the baseline results. While the economic magnitude of the estimates becomes smaller, we still reject at the $1 \%$ level the null that all of the coefficients of the dummy variables are equal to each other. Columns 6-7 in Table A-1 show that excluding voluntary turnover firmyears from the sample yields qualitatively and quantitatively similar results. Finally, we also obtain similar results if we exclude all observations of a CEO that leaves voluntarily - these results are not tabulated. Overall, the results of these tests suggest that our treatment of voluntary turnovers does not affect our results.

Additional control variables. The relation between CEO contract horizon and turnover probability is robust to the inclusion of additional independent variables. In Table A-3, we estimate models of CEO turnover controlling for CEO contract horizon dummies as well as a several control variables motivated by prior literature. We control for ROA, tenure performance, size, whether the firm pays a dividend, the B/M ratio (Jenter and Lewellen, 2014), institutional ownership (Denis, Denis, and Sarin, 1997; Parrino, Sias, and Starks, 2003), CEO age (Parrino, 1997; Jenter and Lewellen, 2015), the percentage of independent directors (Weisbach, 1988; Guo and Masulis, 2015), and the percentage of directors on the board who are "busy" by the definition of Fich and Shivdasani (2006) - which is that they serve on more than 3 boards. We estimate the turnover models in three functional forms: OLS (linear probability model), logit, and Cox hazard model. Because the additional variables on board characteristics reduce our sample size, we estimated two separate specifications with and without them. All of our results hold across functional forms and with these additional control variables.

The performance sensitivity of CEO turnover. The main analysis of the paper shows the sensitivity of CEO turnover to industry-adjusted performance measures. We examine the robustness of these findings by using raw measures of performance (past-year returns or tenure performance, as in Table 5). These models are shown in Table A-4 (Columns 1 and 4). Furthermore, we also verify that the 
choice of functional form does not alter our results on how contracts affect the performance-sensitivity of CEO turnover. Columns 2 and 5 in Table A-4 show that our results hold when using logit models, while Columns 3 and 6 in Table A-4 show that our results are also similar using Cox proportional hazard models. 


\section{Table A-1: Remaining years under contract and turnover probability - robustness}

This table summarizes estimates from models of CEO turnover. Column 1 shows estimates from a logit regression, while Columns 2-7 show estimates from linear probability models of CEO turnover, reporting coefficient estimates with standard errors given underneath. The dependent variable is a dummy set to 1 only for the years in which a firm's CEO leaves. In Columns 4 and 5, following Jenter and Kanaan (2015), we treat involuntary CEO turnover events as right-censored observations. In Columns 6 and 7, we remove firm-year observations with involuntary turnover. Independent variables are defined in Appendix A of the paper. Standard errors (in parentheses) are robust to heteroskedasticity and are clustered at the CEO level. The data span the years 1992-2008. Asterisks indicate that the estimates are significantly different from zero at the *** $1 \%$ level, $* * 5 \%$ level, and $* 10 \%$ level.

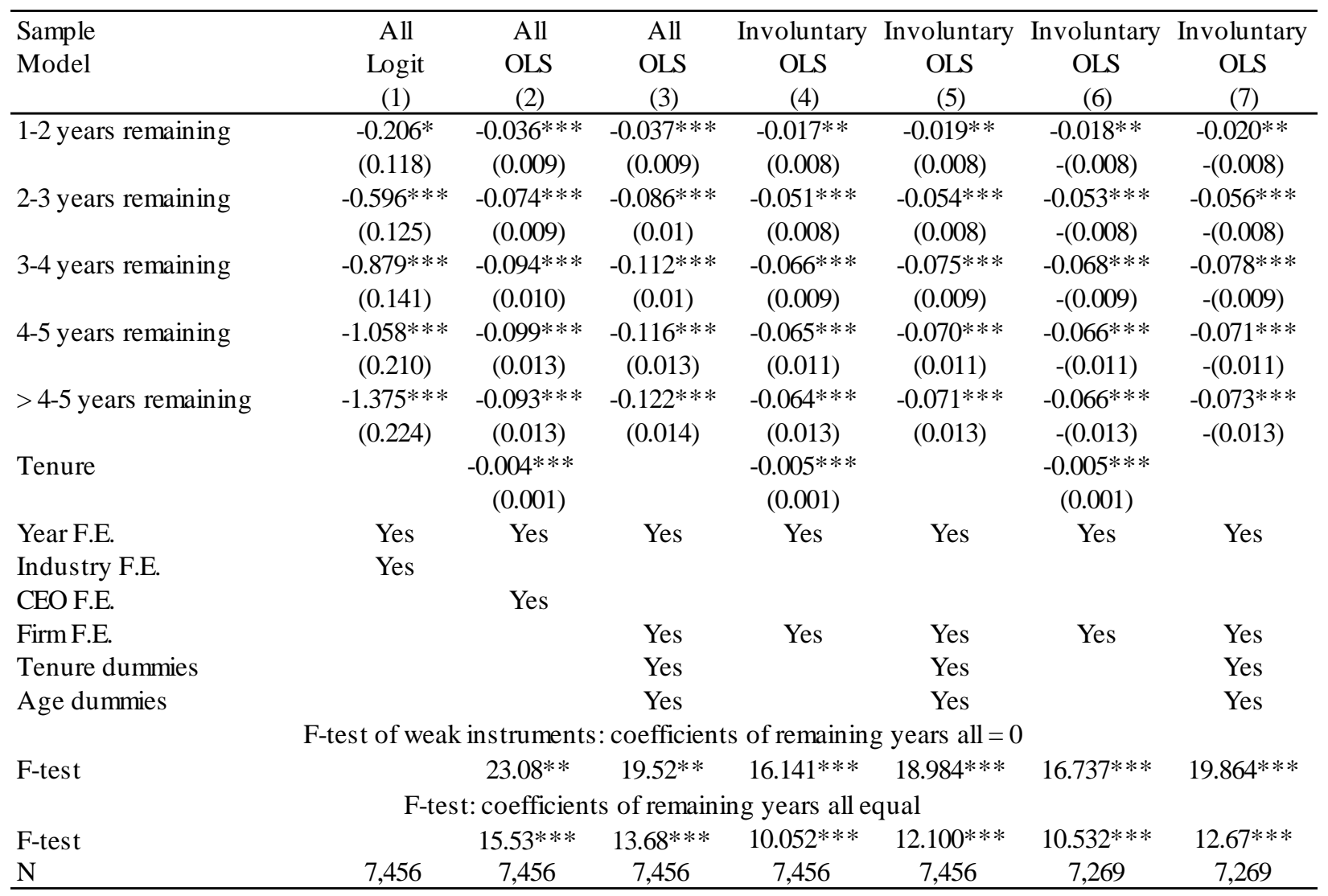




\section{Table A-2: Turnover data}

This table presents univariate statistics of turnover events. We obtain information on the nature of CEO turnovers in our sample from Eisfeldt and Kuhnen (2013), Peters and Wagner (2013), and Jenter and Kanaan (2015). Finally, for the remaining turnover events, we conduct our own search (see Column 3). The data span the years 1992-2008.

\begin{tabular}{lcccc}
\hline Data source & $\begin{array}{c}\text { Eisfeldt and } \\
\text { Kuhnen (2013) }\end{array}$ & $\begin{array}{c}\text { Peters-Wagner (2013) and } \\
\text { Jenter and Kanaan (2015) }\end{array}$ & $\begin{array}{c}\text { Our own } \\
\text { search }\end{array}$ & Total \\
\hline Voluntary ("exogenous") turnover & 135 & & 52 & \\
Forced turnover & 69 & 140 & 207 & \\
Unclassified turnover & 254 & & & \\
Total & $\mathbf{4 5 8}$ & $\mathbf{1 4 0}$ & $\mathbf{2 5 9}$ & $\mathbf{8 5 7}$ \\
\hline
\end{tabular}




\section{Table A-3: Additional control variables in CEO turnover models}

Columns 1-2 present estimates from linear probability models of CEO turnover, and Columns 3-4 contain estimates from logit models of CEO turnover, reporting coefficient estimates with standard errors underneath. Columns 5-6 show the results from Cox proportional hazard models, reporting hazard ratios for CEO turnover with standard errors underneath. Independent variables are defined in Appendix A. Standard errors are clustered at the CEO level. The data span the years 1992-2008. Asterisks indicate that the estimates are significantly different from zero at the *** $1 \%$ level, ** $5 \%$ level, and * $10 \%$ level.

\begin{tabular}{|c|c|c|c|c|c|c|}
\hline \multirow[b]{2}{*}{ Model } & \multicolumn{6}{|c|}{ Models of CEO turnover } \\
\hline & $\begin{array}{l}\text { OLS } \\
\text { (1) }\end{array}$ & $\begin{array}{l}\text { OLS } \\
\text { (2) }\end{array}$ & $\begin{array}{c}\text { Logit } \\
\text { (3) }\end{array}$ & $\begin{array}{l}\text { Logit } \\
\text { (4) }\end{array}$ & $\begin{array}{l}\text { Cox } \\
(5)\end{array}$ & $\begin{array}{l}\text { Cox } \\
(6)\end{array}$ \\
\hline Tenure & $\begin{array}{c}-0.002 * * * * \\
(0.001)\end{array}$ & $\begin{array}{c}-0.002 * * \\
(0.001)\end{array}$ & $\begin{array}{c}-0.033 * * \\
(0.013)\end{array}$ & $\begin{array}{c}-0.041 * * \\
(0.019)\end{array}$ & & \\
\hline $1-2$ years remaining & $\begin{array}{c}-0.026^{* *} \\
(0.010)\end{array}$ & $\begin{array}{c}-0.079 * * * \\
(0.021)\end{array}$ & $\begin{array}{c}-0.273^{* * * *} \\
(0.105)\end{array}$ & $\begin{array}{c}-0.830^{* * *} \\
(0.232)\end{array}$ & $\begin{array}{c}0.844 \\
(0.102)\end{array}$ & $\begin{array}{c}0.489 * * * \\
(0.104)\end{array}$ \\
\hline 2-3 years remaining & $\begin{array}{c}-0.054 * * * \\
(0.013)\end{array}$ & $\begin{array}{c}-0.088 * * * \\
(0.025)\end{array}$ & $\begin{array}{c}-0.658 * * * \\
(0.163)\end{array}$ & $\begin{array}{c}-1.015^{* * *} \\
(0.275)\end{array}$ & $\begin{array}{c}0.656^{* * * *} \\
(0.087)\end{array}$ & $\begin{array}{c}0.465^{* * * *} \\
(0.099)\end{array}$ \\
\hline 3-4 years remaining & $\begin{array}{c}-0.073 * * * \\
(0.010)\end{array}$ & $\begin{array}{c}-0.125^{* * *} \\
(0.022)\end{array}$ & $\begin{array}{c}-0.996 * * * \\
(0.150)\end{array}$ & $\begin{array}{c}-1.810^{* * *} \\
(0.287)\end{array}$ & $\begin{array}{c}0.470 * * * \\
(0.073)\end{array}$ & $\begin{array}{c}0.193^{* * * *} \\
(0.059)\end{array}$ \\
\hline 4-5 years remaining & $\begin{array}{c}-0.081 * * * \\
(0.013)\end{array}$ & $\begin{array}{c}-0.115^{* * *} \\
(0.024)\end{array}$ & $\begin{array}{c}-1.209 * * * \\
(0.261)\end{array}$ & $\begin{array}{c}-1.501 * * * \\
(0.354)\end{array}$ & $\begin{array}{c}0.339 * * * \\
(0.079)\end{array}$ & $\begin{array}{c}0.258 * * * \\
(0.090)\end{array}$ \\
\hline$>5$ years remaining & $\begin{array}{c}-0.090^{* * *} \\
(0.011)\end{array}$ & $\begin{array}{c}-0.131 * * * \\
(0.023)\end{array}$ & $\begin{array}{c}-1.745^{* * *} \\
(0.283)\end{array}$ & $\begin{array}{c}-2.345^{* * * *} \\
(0.407)\end{array}$ & $\begin{array}{c}0.208^{* * *} \\
(0.058)\end{array}$ & $\begin{array}{c}0.124 * * * \\
(0.055)\end{array}$ \\
\hline ROA & $\begin{array}{l}-0.028 \\
(0.021)\end{array}$ & $\begin{array}{l}-0.066 \\
(0.069)\end{array}$ & $\begin{array}{l}-0.361 \\
(0.247)\end{array}$ & $\begin{array}{l}-0.952 \\
(1.119)\end{array}$ & $\begin{array}{c}0.476^{* * * *} \\
(0.133)\end{array}$ & $\begin{array}{c}0.195 \\
(0.231)\end{array}$ \\
\hline Tenure performance & $\begin{array}{c}-0.006^{* *} \\
(0.003)\end{array}$ & $\begin{array}{l}-0.004 \\
(0.005)\end{array}$ & $\begin{array}{l}-0.134 \\
(0.085)\end{array}$ & $\begin{array}{l}-0.080 \\
(0.142)\end{array}$ & $\begin{array}{c}0.794 * * * \\
(0.062)\end{array}$ & $\begin{array}{c}0.842 \\
(0.119)\end{array}$ \\
\hline Ln(assets) & $\begin{array}{c}0.005^{* *} \\
(0.002)\end{array}$ & $\begin{array}{c}0.000 \\
(0.006)\end{array}$ & $\begin{array}{c}0.079 * * \\
(0.032)\end{array}$ & $\begin{array}{c}0.012 \\
(0.086)\end{array}$ & $\begin{array}{c}1.143^{* * * *} \\
(0.040)\end{array}$ & $\begin{array}{c}1.065 \\
(0.088)\end{array}$ \\
\hline Dividend & $\begin{array}{l}-0.007 \\
(0.009)\end{array}$ & $\begin{array}{c}0.001 \\
(0.011)\end{array}$ & $\begin{array}{l}-0.114 \\
(0.138)\end{array}$ & $\begin{array}{c}0.036 \\
(0.181)\end{array}$ & $\begin{array}{c}0.943 \\
(0.108)\end{array}$ & $\begin{array}{c}1.161 \\
(0.239)\end{array}$ \\
\hline $\mathrm{B} / \mathrm{M}$ & $\begin{array}{c}0.002 \\
(0.004)\end{array}$ & $\begin{array}{c}0.022 \\
(0.018)\end{array}$ & $\begin{array}{c}0.029 \\
(0.048)\end{array}$ & $\begin{array}{l}0.362^{*} \\
(0.216)\end{array}$ & $\begin{array}{c}0.962 \\
(0.086)\end{array}$ & $\begin{array}{c}1.388 \\
(0.343)\end{array}$ \\
\hline Institutional ownerhsip (\%) & $\begin{array}{c}-0.051 * * * \\
(0.010)\end{array}$ & $\begin{array}{l}-0.010 \\
(0.016)\end{array}$ & $\begin{array}{c}-0.751 * * * \\
(0.151)\end{array}$ & $\begin{array}{l}-0.057 \\
(0.246)\end{array}$ & $\begin{array}{c}0.490 * * * \\
(0.076)\end{array}$ & $\begin{array}{c}0.972 \\
(0.244)\end{array}$ \\
\hline CEO Age & $\begin{array}{c}0.001 * * * \\
(0.000)\end{array}$ & $\begin{array}{c}0.001 \\
(0.001)\end{array}$ & $\begin{array}{c}0.022 * * * \\
(0.007)\end{array}$ & $\begin{array}{c}0.009 \\
(0.013)\end{array}$ & $\begin{array}{c}0.984 * * * \\
(0.006)\end{array}$ & $\begin{array}{c}0.968 * * * \\
(0.011)\end{array}$ \\
\hline Independent directors $(\%)$ & & $\begin{array}{c}-0.064 * * \\
(0.028)\end{array}$ & & $\begin{array}{c}-1.227^{* * *} \\
(0.416)\end{array}$ & & $\begin{array}{c}0.534 \\
(0.239)\end{array}$ \\
\hline Busy directors (\%) & & $\begin{array}{c}0.041 \\
(0.041)\end{array}$ & & $\begin{array}{c}0.674 \\
(0.638)\end{array}$ & & $\begin{array}{c}2.490 \\
(1.611)\end{array}$ \\
\hline Year F.E. & Yes & Yes & Yes & Yes & Yes & Yes \\
\hline Industry F.E. & Yes & Yes & Yes & Yes & Yes & Yes \\
\hline $\mathrm{N}$ & 6,701 & 2,457 & 6,701 & 2,457 & 6,701 & 2,457 \\
\hline
\end{tabular}




\section{Table A-4: Performance adjustment in turnover models}

This table summarizes models of CEO turnover. Columns 1 and 3 report the results from a Cox proportional hazard model; the values shown are hazard ratios for CEO turnover with standard errors given underneath. Columns 2 and 4 report a logit model where the dependent variable is a dummy for CEO turnover. These columns report coefficient estimates with standard errors given underneath. Tenure performance is stock return measured over the preceding 5 years or since the start of the CEO's tenure, whichever is shorter, scaled by its standard deviation (Jenter and Lewellen 2014). All regressions include industry and year fixed effects. Standard errors (in parentheses) are robust to heteroskedasticity and are clustered at the CEO level. The data span the years 1992-2008. Asterisks indicate that the estimates are significantly different from zero at the *** 1\% level, ** 5\% level, and * $10 \%$ level.

\begin{tabular}{|c|c|c|c|c|}
\hline Model & $\begin{array}{l}\text { Logit } \\
\text { (1) }\end{array}$ & $\begin{array}{l}\text { Cox } \\
\text { (2) }\end{array}$ & $\begin{array}{l}\text { Logit } \\
\text { (3) }\end{array}$ & $\begin{array}{l}\text { Cox } \\
\text { (4) }\end{array}$ \\
\hline $1-2$ years remaining & $\begin{array}{c}-0.2152 * \\
(0.130)\end{array}$ & $\begin{array}{l}0.8781 \\
(0.106)\end{array}$ & $\begin{array}{c}-0.2021 \\
(0.134)\end{array}$ & $\begin{array}{l}0.9100 \\
(0.114)\end{array}$ \\
\hline $2-3$ years remaining & $\begin{array}{c}-0.5769 * * * \\
(0.139)\end{array}$ & $\begin{array}{c}0.6892 * * * \\
(0.090)\end{array}$ & $\begin{array}{c}-0.5410 * * * \\
(0.142)\end{array}$ & $\begin{array}{c}0.7400 * * \\
(0.099)\end{array}$ \\
\hline $3-4$ years remaining & $\begin{array}{c}-0.9257 * * * \\
(0.161)\end{array}$ & $\begin{array}{c}0.4883^{* * *} * \\
(0.075)\end{array}$ & $\begin{array}{c}-0.9193 * * * \\
(0.166)\end{array}$ & $\begin{array}{c}0.4974 * * * \\
(0.079)\end{array}$ \\
\hline 4-5 years remaining & $\begin{array}{c}-1.1808 * * * \\
(0.245)\end{array}$ & $\begin{array}{c}0.3357 * * * \\
(0.080)\end{array}$ & $\begin{array}{c}-1.1243 * * * * \\
(0.246)\end{array}$ & $\begin{array}{c}0.3600 * * * \\
(0.087)\end{array}$ \\
\hline$>5$ years remaining & $\begin{array}{c}-1.6566 \text { *** } \\
(0.285)\end{array}$ & $\begin{array}{c}0.2141 * * * \\
(0.059)\end{array}$ & $\begin{array}{c}-1.6389 * * * \\
(0.291)\end{array}$ & $\begin{array}{c}0.2173 \text { *** } \\
(0.063)\end{array}$ \\
\hline$<1$ year remaining $\times$ return & $\begin{array}{l}-0.1991 \\
(0.170)\end{array}$ & $\begin{array}{c}0.7564^{*} \\
(0.123)\end{array}$ & & \\
\hline $1-2$ years remaining $\times$ return & $\begin{array}{c}-0.6583 * * * \\
(0.189)\end{array}$ & $\begin{array}{c}0.5527 * * * \\
(0.100)\end{array}$ & & \\
\hline $2-3$ years remaining $\times$ return & $\begin{array}{c}-0.7880 * * * \\
(0.222)\end{array}$ & $\begin{array}{c}0.4300 * * * \\
(0.098)\end{array}$ & & \\
\hline $3-4$ years remaining $\times$ return & $\begin{array}{c}-0.0518 \\
(0.219)\end{array}$ & $\begin{array}{l}0.9280 \\
(0.205)\end{array}$ & & \\
\hline $4-5$ years remaining $\times$ return & $\begin{array}{l}0.1236 \\
(0.319)\end{array}$ & $\begin{array}{l}1.1305 \\
(0.374)\end{array}$ & & \\
\hline$>5$ years remaining $\times$ return & $\begin{array}{l}0.0776 \\
(0.340)\end{array}$ & $\begin{array}{l}1.0134 \\
(0.334)\end{array}$ & & \\
\hline$<1$ year remaining $\times$ tenure performance & & & $\begin{array}{c}-0.0893 \\
(0.144)\end{array}$ & $\begin{array}{l}0.8417 \\
(0.117)\end{array}$ \\
\hline $1-2$ years remaining $\times$ tenure performance & & & $\begin{array}{c}-0.3489 * * \\
(0.153)\end{array}$ & $\begin{array}{c}0.6451^{* * * *} \\
(0.102)\end{array}$ \\
\hline $2-3$ years remaining $\times$ tenure performance & & & $\begin{array}{c}-0.5597 * * * \\
(0.191)\end{array}$ & $\begin{array}{c}0.4401 * * * \\
(0.096)\end{array}$ \\
\hline $3-4$ years remaining $\times$ tenure performance & & & $\begin{array}{c}-0.0338 \\
(0.167)\end{array}$ & $\begin{array}{l}0.8878 \\
(0.164)\end{array}$ \\
\hline 4-5 years remaining $\times$ tenure performance & & & $\begin{array}{c}-0.0866 \\
(0.294)\end{array}$ & $\begin{array}{l}0.8587 \\
(0.288)\end{array}$ \\
\hline$>5$ years remaining $\times$ tenure performance & & & $\begin{array}{l}0.0160 \\
(0.260)\end{array}$ & $\begin{array}{l}0.9739 \\
(0.277)\end{array}$ \\
\hline Tenure & $\begin{array}{c}-0.0244 * * * \\
(0.009)\end{array}$ & & $\begin{array}{c}-0.0227 * * * * \\
(0.008)\end{array}$ & \\
\hline Industry F.E. & Yes & Yes & Yes & Yes \\
\hline Year F.E. & Yes & Yes & Yes & Yes \\
\hline $\mathrm{N}$ & 7,113 & 7,113 & 7,113 & 7,113 \\
\hline
\end{tabular}




\section{Appendix C: Model Fit}

Table A-5 compares the fit of our model to alternative models of CEO turnover. Column 1 shows that our baseline OLS model of CEO turnover using contract information, in addition to industry and calendar year FE, has an adjusted $\mathrm{R}^{2}$ of $2.74 \%$. The model uses the same covariates as Jenter and Lewellen (2014), but no contract information has an adjusted $\mathrm{R}^{2}$ of $1.67 \%$. Finally, when we add contract information to the model of Jenter and Lewellen (2014) in Column 3, the adjusted $\mathrm{R}^{2}$ rises substantially (to $2.8 \%$ ). These statistics suggest that using contract information alone provides more accurate predictions of CEO turnover than using firm size, profitability, dividend payer status, tenure performance, and B/M. Moreover, adding contract information to traditional models of CEO turnover results in a meaningful increase of model precision.

To assess the fit of the hazard models, we use two measures (Harrell et al., 1982). The Harrell's C statistic of $68.3 \%$ means that, when one of two CEOs stays in office ("survives") longer than the other one, the probability that the CEO staying in office is assigned a lower hazard ratio by the model plus half the probability that the two have an equal hazard ratio amounts to $68.3 \%$. The Somers' D statistic of $36.7 \%$ means that, when one of two CEOs is observed to stay in office longer than another, the model predicts that the CEO staying in office longer is $36.7 \%$ more likely to have a lower hazard ratio than the dismissed CEO. Hence, a higher value on both numbers indicates a better model fit.

After assessing the fit of our baseline specification in Column 4 of Table A-5, we compare the fit to a hazard model that uses the same covariates as Jenter and Lewellen (2014), but no contract information. Similarly to the case of the OLS models, both goodness-of-fit measures are lower for the model that does not contain contract information as compared the model in Column 4. Finally, in Column 6, we explore how much more accurately we can predict CEO turnover by including contract information. When comparing the fit to the model in Column 5, Harrell's C increases from $67.6 \%$ to $70.8 \%$, i.e. by 3.2 percentage points (or $4.7 \%$ in relative terms). Somers' D increases from $35.2 \%$ to $41.5 \%$, i.e. by 6.3 percentage points (or $17.9 \%$ in relative terms). 


\section{Table A-5: Predictive power of CEO turnover models with and without contract terms}

Columns 1-3 present estimates from linear probability models of CEO turnover, reporting coefficient estimates with standard errors underneath. Columns 4-6 show the results from Cox proportional hazard models, reporting hazard ratios for CEO turnover with standard errors underneath. Independent variables are defined in Appendix A. Standard errors are clustered at the CEO level. When one of two CEOs stays in office longer than another, Harrell's Cstatistic measures the probability that the CEO staying in office is assigned a lower hazard ratio by the model plus half the probability that the two have an equal hazard ratio. When one of two CEOs is observed to stay in office longer than the other, the Somers' D-statistic measures how much more likely it is that the hazard model estimates a lower hazard ratio for the surviving CEO than the dismissed CEO. The data span the years 1992-2008. Asterisks indicate that the estimates are significantly different from zero at the *** 1\% level, ** 5\% level, and * 10\% level.

\begin{tabular}{|c|c|c|c|c|c|c|}
\hline Model & $\begin{array}{c}\text { OLS } \\
(1)\end{array}$ & $\begin{array}{c}\text { OLS } \\
(2)\end{array}$ & $\begin{array}{c}\text { OLS } \\
(3)\end{array}$ & $\begin{array}{c}\text { Cox } \\
(4)\end{array}$ & $\begin{array}{c}\text { Cox } \\
(5)\end{array}$ & $\begin{array}{c}\text { Cox } \\
(6)\end{array}$ \\
\hline Tenure & $\begin{array}{c}-0.0012 * \\
(0.001)\end{array}$ & $\begin{array}{c}-0.0015^{* *} * \\
(0.001)\end{array}$ & $\begin{array}{c}-0.0015^{* *} \\
(0.001)\end{array}$ & & & \\
\hline $1-2$ years remaining & $\begin{array}{c}-0.0186 * * \\
(0.008)\end{array}$ & & $\begin{array}{c}-0.0259 * * \\
(0.010)\end{array}$ & $\begin{array}{l}0.9058 \\
(0.100)\end{array}$ & & $\begin{array}{l}0.8419 \\
(0.102)\end{array}$ \\
\hline $2-3$ years remaining & $\begin{array}{c}-0.0525^{* * *} * \\
(0.011)\end{array}$ & & $\begin{array}{c}-0.0538 * * * \\
(0.013)\end{array}$ & $\begin{array}{c}0.6981 * * * \\
\quad(0.083)\end{array}$ & & $\begin{array}{c}0.6640 * * * \\
(0.087)\end{array}$ \\
\hline 3-4 years remaining & $\begin{array}{c}-0.0649 * * * \\
(0.008)\end{array}$ & & $\begin{array}{c}-0.0726 * * * \\
(0.010)\end{array}$ & $\begin{array}{c}0.5249 * * * \\
(0.071)\end{array}$ & & $\begin{array}{c}0.4704 * * * \\
(0.072)\end{array}$ \\
\hline 4-5 years remaining & $\begin{array}{c}-0.0731 * * * \\
(0.010)\end{array}$ & & $\begin{array}{c}-0.0807 * * * \\
(0.013)\end{array}$ & $\begin{array}{c}0.3800 * * * \\
(0.077)\end{array}$ & & $\begin{array}{c}0.3399 * * * * \\
(0.079)\end{array}$ \\
\hline$>5$ years remaining & $\begin{array}{c}-0.0764 * * * \\
(0.010)\end{array}$ & & $\begin{array}{c}-0.0880 * * * \\
(0.011)\end{array}$ & $\begin{array}{c}0.2729 * * * \\
(0.060)\end{array}$ & & $\begin{array}{c}0.2049 * * * \\
(0.057)\end{array}$ \\
\hline ROA & & $\begin{array}{l}-0.0079 \\
(0.009)\end{array}$ & $\begin{array}{l}-0.0062 \\
(0.009)\end{array}$ & & $\begin{array}{c}0.4000 * * * \\
(0.109)\end{array}$ & $\begin{array}{c}0.4326 * * * \\
(0.119)\end{array}$ \\
\hline Tenure performance & & $\begin{array}{l}0.0079 \\
(0.005)\end{array}$ & $\begin{array}{l}0.0079 \\
(0.005)\end{array}$ & & $\begin{array}{c}0.7869 * * * \\
(0.061)\end{array}$ & $\begin{array}{c}0.7939 * * * \\
(0.061)\end{array}$ \\
\hline Ln(assets) & & $\begin{array}{l}0.0027 \\
(0.002)\end{array}$ & $\begin{array}{l}0.0028 \\
(0.002)\end{array}$ & & $\begin{array}{c}1.0840 * * \\
(0.037)\end{array}$ & $\begin{array}{c}1.0964 * * * \\
(0.037)\end{array}$ \\
\hline Dividend & & $\begin{array}{l}-0.0365 \\
(0.023)\end{array}$ & $\begin{array}{l}-0.0343 \\
(0.021)\end{array}$ & & $\begin{array}{l}0.9044 \\
(0.102)\end{array}$ & $\begin{array}{l}0.9096 \\
(0.103)\end{array}$ \\
\hline $\mathrm{B} / \mathrm{M}$ & & $\begin{array}{c}-0.0066^{* *} \\
(0.003)\end{array}$ & $\begin{array}{c}-0.0067 * * \\
(0.003)\end{array}$ & & $\begin{array}{l}1.0561 \\
(0.068)\end{array}$ & $\begin{array}{l}1.0365 \\
(0.072)\end{array}$ \\
\hline Year F.E. & Yes & Yes & Yes & Yes & Yes & Yes \\
\hline Industry F.E. & Yes & Yes & Yes & Yes & Yes & Yes \\
\hline Adjusted R-squared & $2.74 \%$ & $1.67 \%$ & $2.80 \%$ & & & \\
\hline Harrell's C & & & & 0.683 & 0.676 & 0.708 \\
\hline Somers' D & & & & 0.367 & 0.352 & 0.415 \\
\hline $\mathrm{N}$ & 7,456 & 6,709 & 6,709 & 7,456 & 6,709 & 6,709 \\
\hline
\end{tabular}




\section{Appendix D: Volatility patterns in firms without fixed-term contracts}

Even in the absence of technological cycles, hiring or renewal decisions can create a sudden increase in volatility. If volatility gradually declines over time as the market learns about the CEO's new plans, these "managerial life cycles" may produce the patterns we report. We use two methods to identify "renewals" in the sample of firms without fixed-term contracts: an implicit measure based on compensation and actual jumps in volatility. This Appendix provides supplementary material on (1) the identification of "renewals" from compensation raises, (2) the matching procedure between firms without fixed-term contracts but significant raises or actual jumps in volatility, and (3) the quality of the match. Results are reported in the paper.

\section{D.1. Volatility around CEO evaluations}

Regardless of whether or not CEOs have fixed-term contracts, boards evaluate their performance at appropriate intervals and decide whether to keep them. One way to identify such performance evaluations are significant raises in compensation. This logic follows Gao, Harford, and Li (2012) who show that cuts in CEO compensation predict turnover and interpret it as a vote of no confidence. In unreported results we verify that in our baseline sample of CEOs with fixed-term contracts, contract renewals are indeed followed by a raise of on average $15 \%$, indicating that evaluations coincide with these raises. If purely technological reasons drive our results, we should see similar patterns around evaluations of CEOs without fixed-term contracts. However, Panel C in Table 11 of the paper shows that CEOs without fixedterm contracts are associated (albeit not significantly differently) with more volatility, idiosyncratic risk, and investment just before, not after evaluations. Hence, to the extent that, similar to the contract renewal for fixed-term CEOs, compensation increases to CEOs without fixed-term contracts are a good measure of evaluations, we do not observe a cycle related to "reappointment based on new ideas".

We show similar results using a matched-sample approach. Here, we relate volatility of firms without fixed-term contracts to a "contract horizon" obtained from matched firms where a renewal contract started in the same year as the compensation peak in the firm without a contract, our proxy for an 
evaluation year. We perform a nearest neighbor matching to find, for each at-will firm-year observation with a raise of over $15 \%$, a matching fixed-term contract renewal year using two different sets of requirements. First, we match observations on size (measured as total assets) and Tobin's Q. Second, we use nearest neighbor matching for these two variables, but also require that the matched fixed-term observation should be in the same (Fama-French 48) industry as the at-will observation. Finally, after matching the observations, we use the contract length of the fixed-term observation to measure contract cycles for the CEO employed at will. The increase in compensation pins down the start of the cycle, making it possible to obtain the number of years remaining in the cycle.

\section{D.2. Matching on volatility peaks}

Raises in compensation may happen for reasons other than evaluations for new ideas. For example, some firms may reward the CEO for carrying out those ideas, netting out the volatility-effects of compensation. To see whether abrupt increases in volatility decrease gradually in conjunction with evaluation cycles, we also explicitly choose firms (without fixed-term contract) with large volatility increases. As a cutoff, we use the 20bps rise in volatility around renewals from our baseline results in Table 6 . We then match these firms to those with fixed-term contracts as described above, with the difference that we match CEOs with volatility peaks over 20 basis points instead of compensation peaks.

Out of a total of 4,588 observations, there are 944 such "volatility-peak" observations. We discard 74 observations in the year of a CEO turnover event, because the rise in volatility can be related to speculation about succession and/or learning about CEO ability as in Pan, Wang, and Weisbach (2015). We match the remaining 871 observations to observations under fixed-term contracts where (i) the CEO was renewed and thus was allowed to start a new cycle; (ii) the firm is in the same (FF 48) industry; (iii) in the remaining set of observations, the firm-year is closest to the at-will observation in size (total assets) and market-to-book. We are able to match 850 observations, with $21(2.4 \%)$ unmatched because there is no renewed fixed-term CEO in the same industry. Internet Appendix G discusses match quality in detail. 
Once the matching is complete, we use the contract length of the matched fixed-term CEO to measure the technological cycle of the at-will CEO. If firms choose contracts to have the same length as technological cycles, then the technological cycle of the CEO employed at-will should be similar as the contract length of a similar fixed-term CEO. We then regress volatility on the remaining time in the imputed technological cycle. In this analysis, we exclude the initial observations with the volatility peak, as, by construction, this would hard-wire a correlation between remaining years and volatility.

\section{D.3. Match quality}

Table A- 6 provides detailed information on the quality of the match between the at-will observations. Panels $\mathrm{A}$ and $\mathrm{C}$ of Table 11 show our tests on match quality for volatility peaks. Panel A shows descriptive statistics of selected variables, as well as paired t-tests of equality between the at-will and matched fixed-term observations for the matching sample where we do not require an exact industry match. First, we examine the quality of the match for the matching variables: total assets and Tobin's Q. Total assets average $\$ 2,115$ million for at-will observations and $\$ 2,125$ million for fixed-term observations. Although the difference is statistically significant, on average, it is economically small at $0.46 \%$ of the mean value. Tobin's $Q$ is very closely matched at 2.44 for at-will and 2.42 for fixed-term observations. The results of t-test suggest that we cannot reject the null that the average difference within matched pairs is zero.

To have a more precise sense of match quality, we also examine differences along a number of variables that we do not match on. For example, even though we do not match observations on tenure, the tenure of at-will and fixed-term CEOs is quite similar (7.31 years vs. 6.91 years, respectively). The difference is not statistically significant. CEOs of at-will firms are significantly (1.93 years) younger than their matched counterparts. At-will observations have higher volatility, higher idiosyncratic risk, and higher beta than matched fixed-term observations. Although capital expenditures are not significantly different across the two groups, at-will firms have higher R\&D. Finally, we also examine the length of the technological cycles for the at-will and matched fixed-term firms. At-will firms appear to have longer 
cycles when we use peaks of capital expenditures (sales, or depreciation) to infer cycle length. However, when using troughs of the respective variables, we find that sales cycles of at-will firms are significantly longer (8.52 years vs. 6.45years, respectively). With this one exception, most technological cycle variables have higher means in the fixed-term sample, though the difference is not always statistically significant.

Panel $\mathrm{C}$ in Table A-6 shows similar statistics for the case when we perform the matching requiring an exact match on industry. (When performing this match, we drop 2 at-will firm-year observations from the sample, because there is no exact industry match that has a contract renewal. Hence, the averages for the at-will sample may also differ slightly from the values in the first matching exercise.) Not surprisingly, the industry match requirement renders the match on the two other match variables — size and Tobin's Q_-less precise. The average matched firm with fixed-term contracts is now smaller, with $\$ 1,977$ in total assets. The difference is statistically significant; however, in economic terms, it is only $6.54 \%$ of the sample mean. Tobin's Q is now significantly lower for matched fixed-term observations at 2.14 (vs. 2.44).

Turning to other variables that we do not include in the matching, we see that tenure is still quite similar across observations. As before, age, volatility, idiosyncratic risk, beta, and R\&D are higher for atwill firms. Capital expenditures are now also significantly higher (by the margin of $12.94 \%$ ). Finally, there is no clear pattern regarding the length of technological cycles: at-will firms have longer cycles according to some measures, but shorter cycles according to others.

We also evaluate the quality of the match when we use compensation increases, rather than volatility peaks, to infer CEO renewal cycles at at-will firms. Panel B in Table A-6 shows statistics of match quality for matches formed based on total assets and Tobin's Q, not requiring that the firms be in the same industry. First, from the first two rows in Table 9, it is evident that the matching is almost perfect along the dimensions that we impose. Total assets average $\$ 1,305$ million for at-will observations and \$1,299 million for fixed-term observations. The difference is not statistically significant and is 
economically small $(0.46 \%$ of the mean value). Tobin's $Q$ is very closely matched at 2.32 for both groups. The results of t-test do not reject the null that the average difference within matched pairs is zero.

Second, turning to characteristics that we do not match on, it appears that CEO age and tenure are also closely matched. Specifically, by imposing the match on total assets and Tobin's Q, we actually end up with CEO tenure values that are quite similar at 4.46 years for at-will and 4.62 for matched fixed-term CEOs. CEO age is also remarkably similar at 53.13 and 53.46 years. Neither of these differences is statistically significant. Similarly to the matching exercise based on volatility peaks, we once again find that volatility, idiosyncratic risk and beta, as well as capital expenditures and R\&D are higher for at-will firms than for matched fixed-term firms. These differences underscore the importance of controlling for CEO (or firm) fixed effects in our regressions. Finally, measures of capital expenditure, sales, and depreciation cycles tend to be somewhat higher for fixed-term observations; however, this result reverses if we use troughs in sales to measure cycles (similarly to the matching exercise using volatility peaks) and are not statistically significant for most variables.

In Panel D of Table A-6, statistics are similar to those of the case when we perform the matching requiring an exact match on industry. Once again, the industry match requirement renders the match on the two other match variables—-size and Tobin's Q-less precise. The average matched firm is now smaller, with $\$ 1,287$ million in total assets vs. the $\$ 1,305$ million of the at-will firms. While the difference is statistically significant, in economic terms, it is only $1.37 \%$ of the sample mean. Tobin's $\mathrm{Q}$ is now significantly lower for matched fixed-term observations (2.17 vs. 2.34 , respectively). However, the difference is small in economic terms (6.5\% of the mean).

Turning to other variables that we do not include in the matching, tenure is slightly higher for matched fixed-term observations than for at-will observations (4.71 vs. 4.37 years). In economic terms, the difference of $1 / 3$ year is still moderate. CEO age is not significantly different across at-will and matched observations. As before, volatility, idiosyncratic risk, beta, and R\&D are higher for at-will firms. Capital expenditures are not significantly different, however. Finally, there is no clear pattern regarding 
the length of technological cycles: at-will firms have longer cycles according to some measures, but shorter cycles according to others.

\section{Table A-6: Match quality}

This table presents summary statistics for observations of CEOs employed at will and matched observations of CEOs employed under fixed-term contracts, using the nearest neighbor matching method. In each panel, we show the means of the two match variables, total assets and Tobin's Q, as well as a number of additional variables that were not used to create the match. First, we show the means of the variables for the at-will group and the matched fixed-term observations. The asterisks indicate the result of a paired t-test examining whether the average difference across matched pairs is zero. Next, we show the average difference in terms of the levels of the variable and finally, we show the average difference as a percentage. Panels A and C, we identify evaluation points in at-will contracts based on volatility peaks, defined as increases of over $20 \%$ in volatility. In Panels B and D, we identify evaluation points based in at-will contracts based on compensation peaks, defined as increase of over $15 \%$ in total compensation, the average raise in compensation following renewals in our sample of fixed-term contracts. In the Panels A and B, we match on total assets and Tobin's Q. In Panels C and D, we match on total assets and Tobin's Q and additionally require the matched observation to be in the same Fama-French 49 industry as the at-will observation. 


\begin{tabular}{|c|c|c|c|c|c|c|c|c|}
\hline \multicolumn{9}{|c|}{ Exact match on industry: No } \\
\hline & \multicolumn{4}{|c|}{ Panel A: At-will cycle: volatility peak } & \multicolumn{4}{|c|}{ Panel B: At-will cycle: compensation peak } \\
\hline & At-will & Fixed-term Diff. & Levels & as $\%$ & At-will & Fixed-term Diff. & Levels & as $\%$ \\
\hline \multicolumn{9}{|c|}{ Test of equality for the match variables } \\
\hline Total assets & 2115.38 & $2125.15 * * *$ & -9.76 & $-0.46 \%$ & 1304.77 & 1298.78 & 5.99 & $0.46 \%$ \\
\hline Tobin's Q & 2.44 & 2.42 & 0.02 & $0.87 \%$ & 2.32 & 2.32 & -0.01 & $-0.22 \%$ \\
\hline \multicolumn{9}{|c|}{ Test of equality for selected other variables } \\
\hline Tenure & 7.31 & 6.91 & 0.40 & $5.46 \%$ & 4.46 & 4.62 & -0.15 & $-3.43 \%$ \\
\hline Age & 54.37 & $56.29 * * *$ & -1.93 & $-3.54 \%$ & 53.13 & 53.46 & -0.32 & $-0.61 \%$ \\
\hline Volatility & 3.74 & $2.60 * * *$ & 1.14 & $30.48 \%$ & 3.48 & $3.04 * * *$ & 0.45 & $12.86 \%$ \\
\hline Idiosyncratic risk & 3.37 & $2.36 * * *$ & 1.01 & $29.93 \%$ & 3.24 & $2.83 * * *$ & 0.41 & $12.57 \%$ \\
\hline Beta & 1.09 & $0.99 * * *$ & 0.09 & $8.68 \%$ & 0.96 & $0.90 * *$ & 0.06 & $6.71 \%$ \\
\hline Capital expenditures & 0.07 & 0.07 & 0.00 & $5.97 \%$ & 0.08 & $0.06 * * *$ & 0.01 & $13.89 \%$ \\
\hline$R \& D$ & 0.06 & $0.02 * * *$ & 0.04 & $74.58 \%$ & 0.08 & $0.04 * * *$ & 0.05 & $54.80 \%$ \\
\hline Capex cycle - peaks & 4.67 & $5.45 * * *$ & -0.78 & $-16.74 \%$ & 4.67 & $5.17 * * *$ & -0.50 & $-10.71 \%$ \\
\hline Sales cycle - peaks & 5.15 & 5.46 & -0.31 & $-5.97 \%$ & 4.71 & 5.31 & -0.60 & $-12.73 \%$ \\
\hline Depreciation cycle - peaks & 4.67 & $6.08 *$ & -1.42 & $-30.36 \%$ & 4.66 & 4.87 & -0.21 & $-4.52 \%$ \\
\hline Capex cycle - troughs & 6.01 & $6.92 * * *$ & -0.90 & $-15.01 \%$ & 5.75 & $6.03 *$ & -0.28 & $-4.87 \%$ \\
\hline Sales cycle - troughs & 8.52 & $6.45 * *$ & 2.07 & $24.29 \%$ & 6.51 & 6.05 & 0.46 & $7.05 \%$ \\
\hline Depreciation cycle - troughs & 6.28 & 7.21 & -0.93 & $-14.81 \%$ & 5.98 & 6.08 & -0.10 & $-1.62 \%$ \\
\hline \multicolumn{9}{|c|}{ Exact match on industry: Yes } \\
\hline & \multicolumn{4}{|c|}{ Panel C: At-will cycle: volatility peak } & \multicolumn{4}{|c|}{ Panel D: At-will cycle: compensation peak } \\
\hline & At-will & Fixed-term Diff. & Levels & as $\%$ & At-will & Fixed-term Diff. & Levels & as $\%$ \\
\hline \multicolumn{9}{|c|}{ Test of equality for the match variables } \\
\hline Total assets & 2115.38 & $1977.01 * * *$ & 138.37 & $6.54 \%$ & 1304.77 & $1286.89 * *$ & 17.88 & $1.37 \%$ \\
\hline Tobin's Q & 2.44 & $2.14 * *$ & 0.29 & $12.10 \%$ & 2.32 & $2.17 * * *$ & 0.15 & $6.50 \%$ \\
\hline \multicolumn{9}{|c|}{ Test of equality for selected other variables } \\
\hline Tenure & 7.29 & 6.79 & 0.50 & $6.81 \%$ & 4.37 & $4.71 * * *$ & -0.33 & $-7.62 \%$ \\
\hline Age & 54.31 & $56.33 * * *$ & -2.02 & $-3.71 \%$ & 53.05 & 53.66 & -0.61 & $-1.14 \%$ \\
\hline Volatility & 3.69 & $2.70 * * *$ & 1.00 & $27.00 \%$ & 3.46 & $3.12 * * *$ & 0.34 & $9.95 \%$ \\
\hline Idiosyncratic risk & 3.33 & $2.46 * * *$ & 0.87 & $26.07 \%$ & 3.22 & $2.92 * * *$ & 0.30 & $9.35 \%$ \\
\hline Beta & 1.10 & $0.93 * * *$ & 0.17 & $15.36 \%$ & 0.94 & $0.88 * * *$ & 0.06 & $6.45 \%$ \\
\hline Capital expenditures & 0.07 & $0.06 * *$ & 0.01 & $12.94 \%$ & 0.08 & 0.07 & 0.01 & $13.38 \%$ \\
\hline $\mathrm{R} \& \mathrm{D}$ & 0.06 & $0.02 * * *$ & 0.04 & $70.46 \%$ & 0.09 & $0.03 * * *$ & 0.05 & $61.74 \%$ \\
\hline Capex cycle - peaks & 4.88 & $5.39 * *$ & -0.52 & $-10.61 \%$ & 4.70 & $5.13 * * *$ & -0.43 & $-9.14 \%$ \\
\hline Sales cycle - peaks & 5.25 & 5.50 & -0.25 & $-4.76 \%$ & 4.78 & 5.53 & -0.75 & $-15.70 \%$ \\
\hline Depreciation cycle - peaks & 5.58 & 4.58 & 1.00 & $17.92 \%$ & 3.88 & 3.56 & 0.31 & $8.06 \%$ \\
\hline Capex cycle - troughs & 5.92 & $6.77 * * *$ & -0.86 & $-14.45 \%$ & 5.67 & 6.07 & -0.39 & $-6.95 \%$ \\
\hline Sales cycle - troughs & 8.61 & $5.74 * *$ & 2.87 & $33.33 \%$ & 7.20 & $6.24 * *$ & 0.96 & $13.35 \%$ \\
\hline Depreciation cycle - troughs & 6.94 & 6.67 & 0.27 & $3.88 \%$ & 6.16 & 6.41 & -0.25 & $-4.06 \%$ \\
\hline
\end{tabular}




\section{Appendix E: Magnitudes in terms of turnover probability}

Our results suggest a causal effect of career concerns on volatility. In this section, we take this channel more seriously and estimate magnitudes in a two-stage least squares (2SLS) regression that uses contract horizon as a predictor for turnover probability in the first stage.

Column 1 in Table A-7, Panel A shows our baseline model, estimated using an instrumental variables (IV) approach: the endogenous regressor in the second stage is the dummy for CEO turnover, which we instrument using the remaining years on the CEO's contract. The first stage is estimated using the specification shown in Column 1 of Table 5. The estimated model reveals a strong negative correlation between predicted turnover probability and return volatility. Lower CEO turnover probability is associated with significantly greater volatility. The values in Column 1 indicate that an increase of one standard deviation in turnover probability corresponds to a reduction of 31 basis points (bp) in return volatility. The 31 basis points correspond to $18 \%$ of one standard deviation in return volatility. Columns 2 and 3 show that these results also hold when we use our alternative measures of volatility: the mean of the absolute value of daily returns and the median of the absolute value of daily returns.

Similarly to our analysis in Table 7, we decompose volatility into systematic and idiosyncratic risk. Column 2 in Panel A of Table A-7 shows that the negative relation between return volatility and turnover probability is driven by idiosyncratic risk. An increase of one standard deviation in the likelihood of turnover corresponds to a 36 -bp decrease in idiosyncratic risk (which is $20 \%$ of one standard deviation of idiosyncratic risk). Column 3 of Table A-7, Panel A shows that an increase in turnover probability is associated with no (or very minor) reductions in systematic risk.

We also replicate our evidence on the sources of risk. Column 4 in Panel A of Table A-7 shows the negative association between turnover probability and capital expenditures (normalized by lagged total assets). An increase of one standard deviation in the likelihood of turnover corresponds to a 1.4-bp decrease in capital expenditures (or $15 \%$ of one standard deviation). The results in Column 5 (Table A-7, Panel A) show a significant negative correlation between distance to contract expiration and two leverage factors. The economic significance of this effect is smaller than for investment. An increase of one 
standard deviation in turnover probability corresponds to a decrease of 0.017 in leverage, which amounts to $5 \%$ of the standard deviation of leverage.

The 2SLS specification uses a linear model to predict turnover. In Panel B we show that the estimates are similar when we estimate the turnover probability using a Cox hazard model. Here, we estimate the standard errors using the method of Murphy and Topel (1985).

In Panel C, we address another possibility of a nonlinear relation between turnover likelihood and return volatility. The career outcome for a CEO with extremely high or low turnover probability can be so certain that there is no compelling reason for to change behavior. We regress volatility on dummy variables for CEOs with turnover probability in the lowest ("low"), highest ("high"), and third and fourth ("medium") quintile. That is, our baseline comparison group is the second quintile. We find the same pattern when using a variety of other classifications. Consistent with our baseline results, for CEOs with high turnover probability, volatility is lower (than the baseline) by $36 \mathrm{bp}$. Medium turnover probability leads to a 23 -bp decrease in volatility. Low turnover probability is not significantly related to volatility. 


\section{Table A-7: Estimates from two-stage models}

This table presents the results of 2SLS regressions (Panel A) and of OLS regressions (Panels B and C), reporting coefficients with standard errors underneath. All models are estimated with CEO fixed effects, and a constant which we do not report. The dependent variable is stated in the column heading. Variables are defined in Appendix A. Standard errors are robust to heteroskedasticity and are clustered at the CEO level. The standard errors in Panels B and C are estimated using the method of Murphy and Topel (1985). The data span the years 1992-2008. Asterisks indicate that the estimates are significantly different from zero at the *** 1\% level, ** 5\% level, and * $10 \%$ level.

\begin{tabular}{|c|c|c|c|c|c|}
\hline \multicolumn{6}{|c|}{ Panel A: 2SLS } \\
\hline Dependent variable & Volatility & Idiosyncratic risk & Beta & Investment & Leverage \\
\hline \multirow[t]{2}{*}{ Turnover estimation } & IV & IV & IV & IV & IV \\
\hline & (1) & (2) & (3) & (4) & (5) \\
\hline \multirow[t]{2}{*}{ Turnover probability } & $-2.349 * * *$ & $-2.825 * * *$ & 0.001 & $-0.113 * * *$ & $-0.127 * * *$ \\
\hline & $(0.243)$ & $(0.242)$ & $(0.001)$ & $(0.014)$ & $(0.037)$ \\
\hline CEO F.E. & Yes & Yes & Yes & Yes & Yes \\
\hline Adjusted $\mathrm{R}^{2}$ & $62 \%$ & $63 \%$ & $39 \%$ & $54 \%$ & $71 \%$ \\
\hline $\mathrm{N}$ & 7,456 & 7,456 & 7,456 & 7,456 & 7,456 \\
\hline \multicolumn{6}{|c|}{ F-test of weak instruments: coefficients of remaining years all $=0$} \\
\hline F-test & \multicolumn{5}{|c|}{$32.11 * *$} \\
\hline \multicolumn{6}{|c|}{ Panel B: Cox hazard model, linear specification } \\
\hline Dependent variable & Volatility & Idiosyncratic risk & Beta & Investment & Leverage \\
\hline \multirow[t]{2}{*}{ Turnover estimation } & $\operatorname{Cox}$ & Cox & $\operatorname{Cox}$ & $\operatorname{Cox}$ & $\operatorname{Cox}$ \\
\hline & $(1)$ & (2) & (3) & (4) & (5) \\
\hline \multirow[t]{2}{*}{ Turnover probability } & $-0.517 * * *$ & $-0.634 * * *$ & 0.001 & $-0.029 * * *$ & -0.03 \\
\hline & $(0.118)$ & $(0.111)$ & $(0.0004)$ & $(0.006)$ & $(0.019)$ \\
\hline CEO F.E. & Yes & Yes & Yes & Yes & Yes \\
\hline Adjusted $\mathrm{R}^{2}$ & $62 \%$ & $63 \%$ & $39 \%$ & $54 \%$ & $71 \%$ \\
\hline $\mathrm{N}$ & 7,456 & 7,456 & 7,456 & 7,456 & 7,456 \\
\hline \multicolumn{6}{|c|}{ Panel C: Cox hazard model, nonlinear effects } \\
\hline Dependent variable & Volatility & Idiosyncratic risk & Beta & Investment & Leverage \\
\hline \multirow[t]{2}{*}{ Turnover estimation } & Cox & Cox & Cox & Cox & Cox \\
\hline & $(1)$ & (2) & (3) & (4) & (5) \\
\hline \multirow[t]{2}{*}{ Low turnover probability } & -0.037 & 0.016 & -0.0003 & 0.005 & 0.013 \\
\hline & $(0.057)$ & $(0.054)$ & $(0.0002)$ & $(0.003)$ & $(0.01)$ \\
\hline \multirow[t]{2}{*}{ Medium turnover probability } & $-0.193 * * *$ & $-0.242 * * *$ & $-0.0004 * *$ & $-0.012 * * *$ & $-0.016 * *$ \\
\hline & $(0.068)$ & $(0.064)$ & $(0.0002)$ & $(0.003)$ & $(0.007)$ \\
\hline \multirow[t]{2}{*}{ High turnover probability } & $-0.246 * * *$ & $-0.244 * * *$ & 0.00030 & $-0.013 * * *$ & 0.002 \\
\hline & $(0.047)$ & $(0.045)$ & $(0.0003)$ & $(0.004)$ & $(0.01)$ \\
\hline CEO F.E. & Yes & Yes & Yes & Yes & Yes \\
\hline Adjusted $\mathrm{R}^{2}$ & $62 \%$ & $63 \%$ & $39 \%$ & $54 \%$ & $71 \%$ \\
\hline $\mathrm{N}$ & 7,456 & 7,456 & 7,456 & 7,456 & 7,456 \\
\hline
\end{tabular}




\section{Appendix F: Selection into the Sample}

Although most companies disclose the length of their CEO's employment contract, some may omit this legally required disclosure, even though their CEO is under a fixed-term contract. To put the number of our sample contracts into perspective: Gillan, Hartzell, and Parrino (2009) survey all S\&P 500 firms in 2000 and find that 255 (or 45\%) of their CEOs had employment contracts. Our sample contains 236 contracts that were in place with S\&P 500 firms in 2000; therefore, 19 (or 3.8\%) are missing. As S\&P 500 firms tend to be large, they are likely to have better disclosure quality. For this reason, a higher percentage of omitted contracts in the rest of our sample is likely.

Since our analysis links the number of years remaining on a CEO's contract to risk, we necessarily focus on CEOs with fixed-term contracts. However, CEOs with fixed-term contracts may differ from other CEOs. Likewise, there could be differences among the firms that offer these various contract types. To control for the selection bias that could emerge from using a non-random sample, we follow the approach of Heckman (1979) and use the choice regression described next to compute the inverse Mills ratio. We use a state law characteristic for the identifying restriction: the at-will exception rule of good faith and fair dealing (henceforth referred to as "the exception rule"). This state-wide rule prohibits terminations made in bad faith or motivated by malice. ${ }^{15}$ This rule protects rank-and-file employees with relatively shorter contracts (or even without contracts), which makes such forms of employment more attractive. The ensuing popularity of shorter contracts makes it difficult for executives to negotiate longer contracts for themselves. However, direct judicial consequences of this rule for CEOs are probably limited because they are already protected by individual contracts. The applicability of atwill exceptions is listed by state in Table A-8 (cf. Walsh and Schwarz 1996; Muhl 2001). In most states, these rules were adopted between 1960 and 1980 (i.e. before our sample's time frame) in response to debates driven both by that era's political sentiments and the particularities of some precedent cases.

\footnotetext{
15 There are two other exceptions that are less relevant for our purposes. Under the public policy exception, dismissal is not allowed if it violates the public policy (or a statute) of the state. Under the implied contract exception, an employee can dispute dismissal by proving the existence of an implicit (i.e. not written) contract.
} 
To identify the firms that do not disclose their CEO contracts, we use the following determinants of disclosure quality: firm size, number of equity issuances, and standard deviation of analyst forecasts. Lang and Lundholm (1993) and Brown and Hillegeist (2007) show that these variables affect disclosure quality as measured by (the since discontinued) AIMR scores. As the determinants are fairly generic firm characteristics, we also include a variable that indicates whether the firm made any earnings restatements in the relevant year (as reported by Audit Dynamics).

We follow Gillan et al. (2009) in choosing other determinants of long-term contracts. These authors argue that labor market risk should be relevant for choosing contract terms; that is, firms operating in riskier industries must more frequently renegotiate contracts. Based on Gillan et al. (2009), we use the following indicators of industry risk: homogeneity of stock returns, volatility of median sales, and annual rate of survival. Both CEO and board characteristics should also affect contract negotiations. In particular, there is less uncertainty about incumbent CEOs, especially when they have been in their position for a long time. A similar argument can be made for older CEOs with a lengthy track record. We control for CEO incumbency, age, and tenure, and use the governance index of Gompers, Ishii, and Metrick (2003) to control for the board's power. To ensure that geographical effects are in fact due to atwill exceptions and not to other legal differences across states, we control—with respect to the state of incorporation - for such geographical indices as the anti-takeover index of Bertrand and Mullainathan (1999) and the anti-competition enforceability index of Garmaise (2011). All regressions contain industry and year fixed effects to control for exogenous shocks to the labor market.

Table A-9 presents the results. Column 1 reports the values for a probit specification that predicts the choice of entering into a fixed-term contract in terms of all the aforementioned variables. Column 2 uses the variables that are found to be significantly associated with contract choice in Column 1 to predict the choice of accepting a fixed-term contract. This regression is used to compute inverse Mills ratios for the regressions reported in Section 4.

In line with Miles (2000), the states with the exception rule are significantly less likely to issue fixed-term contracts. As for the two other geographical variables, the anti-takeover (resp., anti- 
competition enforcement) index is significantly (resp., marginally) related to fixed-term contracts. Therefore, we find that CEOs are more likely to enter fixed-term and longer contracts if anti-takeover laws are in force, which is consistent with the complementarity of external and internal governance (Cremers and Nair 2005).

We find little evidence that firms with lower disclosure quality are less likely to disclose a contract. In defense of the disclosure bias hypothesis, the firms with more equity issuances are more likely to be in the sample, and such firms face more disclosure requirements. That said, smaller firms, as well as firms with more earnings restatements, are less likely to be in the sample of CEOs with a (disclosed) fixed-term contract. That these variables are related to the incidence of such contracts indicates that they measure firm characteristics unrelated to disclosure. The standard deviation of analyst forecasts is not significantly related to contract choice, which also suggests that information asymmetry is of little relevance to sample selection.

Industry homogeneity is associated with fewer contracts. In homogeneous industries, both CEO and firm have more outside options and, accordingly, an employment contract is less important. Our industry risk variables are not significantly related to contract choice. Incumbent CEOs are more likely to receive a fixed-term contract. Older and longer-tenured CEOs are more likely to have no contract, possibly because firms are less uncertain about their potential. The Gompers, Ishii, and Metrick (2003) governance index is positively associated with a firm's use of contracts. This measure is lower for firms with high shareholder orientation. The positive association suggests that a board of directors with less bargaining power is more likely to offer a fixed-term contract.

Table A-10 repeats the regressions from Column 1 of Panel A in Table 7 and Columns 1, 3, 5, and 7 in Table 8 of the paper controlling in addition for the inverse Mills ratio. Our results continue to hold after we control for sample selection. 


\section{Table A-8: At-will exceptions}

This table summarizes the at-will exceptions by state, reporting the laws that prevail in each of the US states as of 2001. The data are from Muhl (2001) and Walsh and Schwartz (1996).

\begin{tabular}{|c|c|c|c|c|}
\hline \multirow[b]{2}{*}{ Code } & \multirow[b]{2}{*}{ State } & \multicolumn{3}{|c|}{ At-will exceptions } \\
\hline & & Public policy & Implied contract & $\begin{array}{l}\text { Good faith and } \\
\text { fair dealing }\end{array}$ \\
\hline$\overline{\mathrm{AL}}$ & Alabama & 0 & 1 & 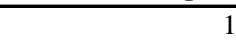 \\
\hline AK & Alaska & 1 & 1 & 1 \\
\hline $\mathrm{AZ}$ & Arizona & 1 & 1 & 1 \\
\hline $\mathrm{AR}$ & Arkansas & 1 & 1 & 0 \\
\hline $\mathrm{CA}$ & California & 1 & 1 & 1 \\
\hline $\mathrm{CO}$ & Colorado & 1 & 1 & 0 \\
\hline $\mathrm{CT}$ & Connecticut & 1 & 1 & 0 \\
\hline DC & District of Columbia & 1 & 1 & 0 \\
\hline $\mathrm{DE}$ & Delaware & 1 & 0 & 1 \\
\hline FL & Florida & 0 & 0 & 0 \\
\hline GA & Georgia & 0 & 0 & 0 \\
\hline HI & Hawaii & 1 & 1 & 0 \\
\hline ID & Idaho & 1 & 1 & 1 \\
\hline $\mathrm{IL}$ & Illinois & 1 & 1 & 0 \\
\hline IN & Indiana & 1 & 0 & 0 \\
\hline IA & Iowa & 1 & 1 & 0 \\
\hline KS & Kansas & 1 & 1 & 0 \\
\hline KY & Kentucky & 0 & 1 & 0 \\
\hline LA & Louisiana & 0 & 0 & 0 \\
\hline ME & Maine & 0 & 1 & 0 \\
\hline MD & Maryland & 1 & 1 & 0 \\
\hline MA & Massachusetts & 1 & 0 & 1 \\
\hline MI & Michigan & 1 & 1 & 0 \\
\hline MN & Minnesota & 1 & 1 & 0 \\
\hline MS & Mississippi & 1 & 1 & 0 \\
\hline MO & Missouri & 1 & 0 & 0 \\
\hline MT & Montana & 1 & 0 & 1 \\
\hline $\mathrm{NE}$ & Nebraska & 0 & 1 & 0 \\
\hline NV & Nevada & 1 & 1 & 1 \\
\hline NH & New Hampshire & 1 & 1 & 0 \\
\hline NJ & New Jersey & 1 & 1 & 0 \\
\hline NM & New Mexico & 1 & 1 & 0 \\
\hline NY & New York & 0 & 1 & 0 \\
\hline $\mathrm{NC}$ & North Carolina & 1 & 0 & 0 \\
\hline ND & North Dakota & 1 & 1 & 0 \\
\hline $\mathrm{OH}$ & Ohio & 1 & 1 & 0 \\
\hline OK & Oklahoma & 1 & 1 & 0 \\
\hline OR & Oregon & 1 & 1 & 0 \\
\hline $\mathrm{PA}$ & Pennsylvania & 1 & 0 & 0 \\
\hline RI & Rhode Island & 0 & 0 & 0 \\
\hline SC & South Carolina & 1 & 1 & 0 \\
\hline $\mathrm{SD}$ & South Dakota & 1 & 1 & 0 \\
\hline $\mathrm{TN}$ & Tennessee & 1 & 1 & 0 \\
\hline $\mathrm{TX}$ & Texas & 0 & 0 & 0 \\
\hline UT & Utah & 1 & 1 & 1 \\
\hline VT & Vermont & 1 & 1 & 0 \\
\hline VA & Virginia & 1 & 0 & 0 \\
\hline WA & Washington & 1 & 1 & 0 \\
\hline WV & West Virginia & 1 & 1 & 0 \\
\hline WI & Wisconsin & 1 & 1 & 0 \\
\hline WY & Wyoming & 1 & 1 & 1 \\
\hline
\end{tabular}




\section{Table A-9: Choice of contract type}

This table presents marginal effects from probit regressions and standard errors (in parentheses) that are robust to 25 eteroscedasticity and clustered by year. The unit of observation is a firm-year. Models are estimated using 7,456 firm-years of CEOs with fixed-term contracts and 23,182 firm-years of CEOs without fixed-term contracts. The dependent variable is a dummy set to 1 if the firm and the CEO have a fixed-term contract (and to 0 otherwise). Exception rule is a dummy variable equal to 1 if the contract is governed by the law of a state with a good faith \& fair dealing at-will exception. Anti-takeover is a dummy variable for a state with "business combination laws" according to Bertrand and Mullainathan (1999). Garmaise is the index of Garmaise (2009). Restatement is a dummy variable equal to 1 if the firm files an earnings restatement in the current year. Industry homogeneity is the median (across all firms of one of the 49 Fama-French industries) of the percentage variation in monthly stock returns that is explained by an equally weighted industry index; market-adjusted returns are annual stock returns adjusted by the value-weighted CRSP index. Industry sales volatility is the (FF 49) industry average of variance in sales over the past seven years. Industry survival rate is the industry rate of year-to-year survival within Compustat. Governance index is the index developed by Gompers, Ishii and Metrick (2003). All other variables are defined in Appendix A. The data span the years 1992-2008. Asterisks indicate that the estimates are significantly different from zero at the $* * * 1 \%$ level, ** $5 \%$ level, and * $10 \%$ level. 


\begin{tabular}{|c|c|c|c|}
\hline \multicolumn{4}{|c|}{ Dependent variable: Fixed-term contract } \\
\hline & & $(1)$ & $(2)$ \\
\hline \multirow[t]{3}{*}{ Geography } & Exception rule & $\begin{array}{c}-0.248^{* * *} \\
(0.01)\end{array}$ & $\begin{array}{c}-0.240 * * * \\
(0.01)\end{array}$ \\
\hline & Anti-takeover & $\begin{array}{c}0.108 * * * \\
(0.01)\end{array}$ & $\begin{array}{c}0.102 * * * \\
(0.01)\end{array}$ \\
\hline & Garmaise & $\begin{array}{c}-0.004 * \\
(0.003)\end{array}$ & \\
\hline \multirow[t]{4}{*}{$\begin{array}{l}\text { Disclosure } \\
\text { quality }\end{array}$} & Assets & $\begin{array}{c}-0.275^{* * *} \\
(0.02)\end{array}$ & $\begin{array}{c}-0.275^{* * * *} \\
(0.02)\end{array}$ \\
\hline & Log number of SEOs & $\begin{array}{c}0.581 * * * \\
(0.01)\end{array}$ & $\begin{array}{c}0.574 * * * \\
(0.01)\end{array}$ \\
\hline & Restatement & $\begin{array}{c}0.175^{* * *} \\
(0.05)\end{array}$ & $\begin{array}{c}0.176^{* * *} \\
(0.05)\end{array}$ \\
\hline & Analyst forecast $\mathrm{SD}$ & $\begin{array}{c}-0.001 \\
(0.0005)\end{array}$ & \\
\hline \multirow[t]{3}{*}{ Risk } & Industry homogeneity & $\begin{array}{c}-0.788 * * \\
(0.34)\end{array}$ & $\begin{array}{c}-1.353 * * * \\
(0.23)\end{array}$ \\
\hline & Industry sales volatility & $\begin{array}{l}0.041 \\
(0.14)\end{array}$ & \\
\hline & Industry survival rate & $\begin{array}{l}0.191 \\
(0.34)\end{array}$ & \\
\hline \multirow[t]{4}{*}{ Governance } & Renewal & $\begin{array}{c}0.317 * * * \\
(0.09)\end{array}$ & $\begin{array}{c}0.317 * * * \\
(0.09)\end{array}$ \\
\hline & Age & $\begin{array}{c}-0.006^{* * *} \\
(0.002)\end{array}$ & $\begin{array}{c}-0.006 * * * \\
(0.002)\end{array}$ \\
\hline & Tenure & $\begin{array}{c}-0.040 * * * \\
(0.003)\end{array}$ & $\begin{array}{c}-0.040 * * * \\
(0.003)\end{array}$ \\
\hline & Governance index & $\begin{array}{c}0.110 * * * \\
(0.007)\end{array}$ & $\begin{array}{c}0.110 * * * \\
(0.007)\end{array}$ \\
\hline \multirow[t]{2}{*}{ Fixed effects } & Industry & Yes & Yes \\
\hline & Year & Yes & Yes \\
\hline Constant & & $\begin{array}{c}-3.157 * * * \\
(0.36)\end{array}$ & $\begin{array}{c}-2.937 * * * \\
(0.18)\end{array}$ \\
\hline $\mathrm{N}$ & & 30,638 & 30,638 \\
\hline
\end{tabular}




\section{Table A-10: Robustness of main results to selection into the sample}

This table presents the results of OLS regressions, reporting coefficients with standard errors underneath. The dependent variable is listed in the column heading. The Inverse Mills' ratio is estimated from the model presented in Table A-9, Column A. All regressions include CEO fixed effects. Standard errors are robust to heteroskedasticity and are clustered at the firm level. The data span the years 1992-2008. Asterisks indicate that the estimates are significantly different from zero at the *** $1 \%$ level, $* * 5 \%$ level, and $* 10 \%$ level.

\begin{tabular}{lccccc}
\hline Dependent variable & Volatility & Beta & Idiosyncratic risk & Investment & Leverage \\
& $(1)$ & $(2)$ & $(3)$ & $(4)$ & $(5)$ \\
\hline Remaining years & $0.035^{* *}$ & -0.00005 & $0.047^{* * *}$ & $0.003^{* * *}$ & $0.006^{* * *}$ \\
& $(0.014)$ & $(0.00004)$ & $(0.013)$ & $(0.000)$ & $(0.002)$ \\
Inverse Mills' ratio & $6.126^{* * *}$ & 0.017 & $5.529^{* * *}$ & 0.019 & -0.362 \\
& $(2.158)$ & $(0.030)$ & $(1.755)$ & $(0.260)$ & $(0.754)$ \\
Constant & 1.066 & 0.004 & $0.996^{*}$ & 0.053 & 0.331 \\
& $(0.689)$ & $(0.010)$ & $(0.561)$ & $(0.083)$ & $(0.241)$ \\
CEO F.E. & Yes & Yes & Yes & Yes & Yes \\
Adjusted R & $61 \%$ & $39 \%$ & $63 \%$ & $55 \%$ & $70 \%$ \\
$\mathrm{~N}$ & 7,456 & 7,456 & 7,456 & 7,456 & 7,456 \\
\hline
\end{tabular}




\section{References}

Berndt, E. R., and Z. Griliches. 1993. Price indices for microcomputers: An exploratory study. In Price Measurements and Their Uses, edited by Murry Foss, Marylin Manser, and Allan Young, 6393. Chicago: University of Chicago.

Bertrand, M., and S. Mullainathan.1999. Is there discretion in wage setting? A test using takeover legislation. RAND Journal of Economics 30: 535-554.

Boualam, Gomes, and Ward. 2015. Understanding the behavior of distressed stocks, Working paper.

Brickley, J.A., 2003. Empirical research on CEO turnover and firm-performance: A discussion. Journal of Accounting and Economics 36: 227-233.

Brown, S., and S. A. Hillegeist. 2007. How disclosure quality affects the level of information asymmetry. Review of Accounting Studies 12: 443-477.

Cremers, K. J. M., and V. B. Nair. 2005. Governance mechanisms and equity prices. Journal of Finance 60: 2859-2894.

Denis, D. J., Denis, D. K., and Sarin, A. 1997. Ownership structure and top executive turnover, Journal of Financial Economics 45: 193-221.

Eisfeldt, A. L., and C. M. Kuhnen. 2013. CEO turnover in a competitive assignment framework. Journal of Financial Economics 109: 351-372.

Garmaise, M. J. 2011. Ties that truly bind: non-competition agreements, executive compensation and firm investment. Journal of Law, Economics \& Organization 27: 376-425.

Gompers, P. A., J. L. Ishii, and A. Metrick. 2003. Corporate governance and equity prices. Quarterly Journal of Economics 118: 107-155.

Goyenko, R., C. Ornthanalai, and S. Tang. 2014. Trading cost dynamics of market making in equity options. Working paper, Rotman School of Management.

Harrell, F. E., R. M. Califf, D. B. Pryor, K. L. Lee, and R. A. Rosati. 1982. Evaluating the yield of medical tests. Journal of the American Medical Association 247: 2543-2546.

Heckman, J. J. 1979. Sample selection bias as a specification error. Econometrica 47: 153-161.

Huson, M. R., R. Parrino, and L. T. Starks. 2001. Internal monitoring mechanisms and CEO turnover: A long term perspective. Journal of Finance 56: 2265-2297.

Lang, M., and R. Lundholm. 1993. Cross-sectional determinants of analyst ratings of corporate disclosures. Journal of Accounting Research 31: 246-271.

Mikkelson, W. H., and M. M. Partch. 1997. The decline of takeovers and disciplinary management turnover. Journal of Financial Economics 44: 205-228.

Miles, T. J. 2000. Common law exceptions to employment at-will and U.S. labor markets. Journal of Law and Economics, and Organization 16: 74-101.

Muhl, C. J. 2001. The employment-at-will doctrine: three major exceptions. Monthly Labor Review 124: $3-11$

Murphy, K. M., and R. H. Topel. 1985. Estimation and inference in two-step econometric models. Journal of Business and Economic Statistics 3: 88-97.

Perez-Gonzalez, F. and H. Yun. 2013. Risk management and firm value: Evidence from weather derivatives. Journal of Finance 68: 2143-2176.

Perry, T., 1999. Incentive compensation for outside directors and CEO turnover. Working paper, University of North Carolina at Chapel Hill.

Peters, F., and A. Wagner. 2014. The executive turnover risk premium. Journal of Finance 69: 15291563.

Rogers, J. L., D. J. Skinner, and A. Van Buskirk. 2009. Earnings guidance and market uncertainty. Journal of Accounting and Economics 48(1): 90-109.

Tufano, P., 1998. The determinants of stock price exposure: financial engineering and the gold mining industry. Journal of Finance 53: 1015-1052.

Walsh, D. J., and J. L. Schwarz. 1996. State common law wrongful discharge doctrines: up-date, refinement, and rationales. American Business Law Journal 33: 645-689. 